\title{
GROWING SEASONS OF ARIZONA \\ AND SONORA
}

by

Yassin Mohmed Ibrahim

\author{
A Thesis Submitted to the Faculty of the \\ DEPARTMENT OF PLANT SCIENCES \\ In Partial Fulfillment of the Requirements \\ For the Degree of \\ MASTER OF SCIENCE \\ In the Graduate College \\ THE UNIVERSITY OF ARIZONA
}


This thesis has been submitted in partial fulfillment of requirements for an advanced degree at The University of Arizona and is deposited in the University Library to be made available to borrowers under rules of the Library.

Brief quotations from this thesis are allowable without special permission, provided that accurate acknowledgment of source is made. Requests for permission for extended quotation from or reproduction of this manuscript in whole or in part may be granted by the head of the major department or the Dean of the Graduate College when in his judgment the proposed use of the material is in the interests of scholarship. In all other instances, however, permission must be obtained from the author.

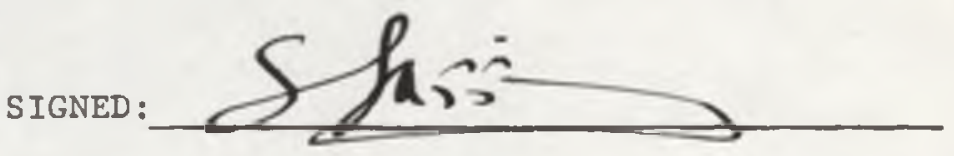

\section{APPROVAL BY THESIS DIRECTOR}

This thesis has been approved on the date shown below:
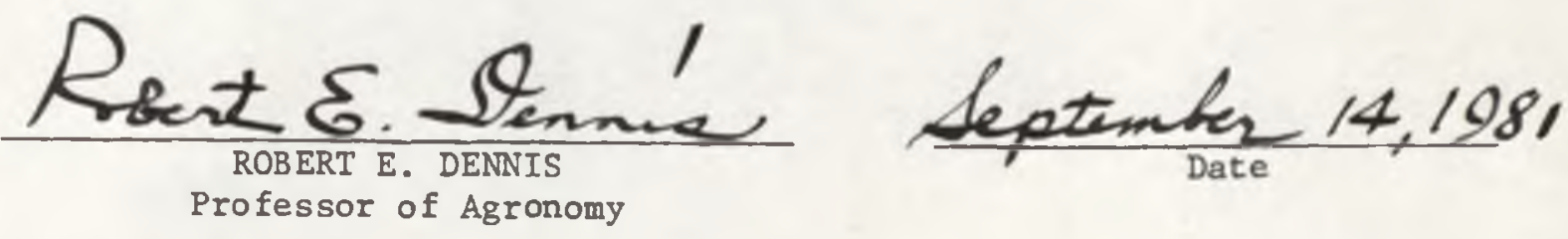


\section{ACKNOWLEDGMENTS}

The author wishes to express sincere thanks to his major professor, Dr. Robert E. Dennis for his guidance, expert assistance, and support during the course of this study.

Appreciation and respect are due to my mother, El Haja, whose love and prayers enlightened my way. I am also grateful to the rest of my family for their encouragement and support.

My expenses for transportation, tuition, books, food, lodging, and other costs were provided by the College of Agricultural Studies, Shambat Institute of Agriculture, and the Government of Sudan. This assistance made my studies at the University of Arizona posstble and for this I will always be grateful. I pledge to do my best to provide assistance and service to my fellowmen that will warrant the support given to me by my Country and my College.

Grateful appreciation is extended to Dr. Arden D. Day and Dr. Norman F. Oebker, who helped with the preparation and review of this manuscript.

Thanks are expressed to Anna Mckew for her typing of draft copies of the manuscript and to Dave Parsons for his help in providing information for the study.

This climatic study was sponsored by the Agricultural Committees of the Arizona-Mexico Commission, and the Sonora-Arizona Commission, L. D. McCorkindale and Germán Pablos Tirado, Co-Chairmen. Antonio 
. Certosimo, Executive Direc̄tor of the Arizona-Mexico Commission, agricultural committee members, and others provided encouragement and assistance throughout the course of the study. Their support was a major factor in enabling the study to be successfully concluded.

Grateful appreciation is expressed to Gaspar Lizarazu 0. and Fernando Durazo C. and to the Union Ganadera de Sonora. The Union Ganadera de Sonora contributed $\$ 500$ to the project, and this was matched by the University of Arizona. These funds furnished the foundation for the successful completion of this study.

Thanks are also given to M. S. Xicotencatl Murrieta, Director of Center of Scientific and Technological Investigation, University of Sonora and to Pilar Angel Zazueta Felix and Jose Borbolla Martinez of the Union Ganadera Regional de Sinaloa for providing climatic information, and their support is gratefully acknowledged. Appreciation Is also expressed to Nancy N. Day, Michele A. Marien, and Melin $\mathrm{H}$. Schonhorst, University of Arizona students, who assisted with data evaluation and presentation.

I am ever grateful to all who helped me in any way. 
TABLE OF CONTENTS

Page

LIST OF TABLES . . . . . . . . . . . . . . . . . . . vi

LIST OF ILLUSTRATIONS . . . . . . . . . . . . . . vii

ABSTRACT . . . . . . . . . . . . . . . . . . . ix

INTRODUCTION . . . . . . . . . . . . . . . . . 1

LITERATURE REVIEW . . . . . . . . . . . . . . . . . 4

Basis of Classifying Climate . . . . . . . . . . . 4

Classification Based on Temperature . . . . . . . . . . 7

The Use of Monthly Mean Temperature, Maximum and Minimum . . 8

Effect of Temperature Distribution on Climatic Classification 10

Horizontal (Lateral) Distribution of Temperature . . . . 12

Correlation between Temperature and Crop Growing Seasons . . . 13

Temperature-Plant Relations . . . . . . . . . . 13

Temperature and Growing Season . . . . . . . . . . 15

The Present Climatic Classifications . . . . . . . . . 17

The Koppen Climate Classification System . . . . . . . 17

Thornthwaite's Classification of Climate . . . . . . . 19

Other Classification Schemes ........... 21

MATERIALS AND METHODS ................ 22

RESULTS AND DISCUSSION ................. 26

Climate Matching............... 55

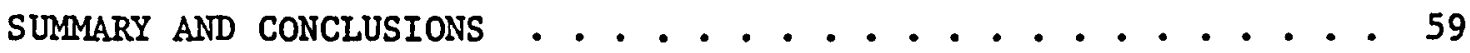

APPENDIX A: AVERAGE MONTHLY TEMPERATURE OF SELECTED LOCATIONS IN ARIZONA AND SONORA ............. 62

LITERATURE CITED . . . . . . . . . . . 72 
LIST OF TABLES

Table

1. General features of terminology used in growing season classification (Average monthly temperature)

2. Extremes of temperature used for classification of climate

3. Climatic data for locations representing year-long, extremely hot growing season climate. . . . . . . . .

4. Climatic data for locations representing year-long, very hot growing season climate ..............

5. Climatic data for locations representing year-long, hot growing season climate............... 34

6. Climatic data for locations representing hot-moderate temperature growing season climate . . . . . . . .

7. Climatic data for locations representing moderate temperature growing season climate ..............

8. Climatic data for a location representing moderate-cool temperature growing season climate ............

9. Matching of climatic data of selected stations around the world to some of the classes obtained in this classification . . . . . . . . . . . . . . . . . 


\section{LIST OF ILLUSTRATIONS}

Figure

Page

1. Growing seasons of Arizona, United States and Sonora, Mexico 27

2. Maximum, mean, and minimum temperature for locations representing year-long, extremely hot growing season climate 29

3. Maximum, mean, and minimum temperatures for locations representing year-long, very hot climate with hot summer . .

4. Maximum, mean, minimum temperatures for locations representing year-long, very hot climate with moderate summer ...........................

5. Maximum, mean, and minimum temperatures for locations representing year-long hot climate with hot summer . . . 35

6. Maximum, mean, and minimum temperatures for locations representing year-long moderate cold growing season climate

7. Maximum, mean, and minimum temperatures for a location representing year-long cold growing season climate . . . . 37

8. Graph comparing maximum, mean, and minimum temperatures of extremely hot (IAw) and very hot (IIACw) year-long growing seasons . . . . . . . . . . . . . . . . 39

9. Graph comparing maximum, mean and minimum temperatures of extremely hot (IAw) and hot (IIIAcw) year-long growing seasons

10. Graph comparing maximum, mean, and minimum temperatures of hot summer (IIACw) and moderate summer (IIBCw) year-long, very hot growing seasons ..................

11. Graph comparing maximum, mean, and minimum temperatures of very hot (IIAW) and hot (IIIACW) year-long growing seasons

12. Graph comparing maximum, mean, and minimum temperatures for three year-long hot growing season climate (IIIACw, IIIBcw, IIICcW)

13. Maximum, mean, and minimum temperatures for locations representing hot-moderate temperature growing season climates 45 
viii

IIST OF ILLUSTRATIONS--Continued

Figure

Page

14. Graph comparing maximum, mean, and minimum temperatures of hot summer (IVACW) and moderate summer (IVBCw) hotmoderate growing season climates . . . . . . . .

15. Maximum, mean, and minimum temperatures for locations representing moderate temperature growing season climates with warm summer ...................

16. Maximum, mean, and minimum temperatures for locations representing moderate temperature growing season climates with moderate summer . . . . . . . . . . . 50

17. Maximum, mean, and minimum temperatures for a location representing moderate temperature growing season climate with cold summer . . . . . . . . . . . . . . .

18. Graph comparing maximum, mean, and minimum temperatures for three moderate-temperature growing season climates (VAw, VBw, VCw) ...................

19. Maximum, mean, and minimum temperatures for a location representing moderate-cool temperature growing season climate ...................... 54 


\begin{abstract}
The climates of Arizona (United States) and Sonora (Mexico) were divided into 20 different types in this study. This division of the land areas according to climate were based upon mean maximum, mean, and mean minimum monthly temperatures that have occurred during periods of record.

Elevation was closely correlated with temperature, with warmest climates at the lower elevations. Latitude played an important part in determining temperature. A method of matching climates was proposed and described. Careful matching of climates facilitates sharing of research and experiences relative to the production of agronomic and horticultural crops.
\end{abstract}




\section{INTRODUCTION}

The climate of any region is a composite of many different meteorological elements and their periodic variations. Due to interaction of these elements, a region may have many climatic types. Trewartha (1968) differentiated between climatic regions as main divisions and climatic types as subdivisions. The many variations in climate from place to place produce a large number of climatic types.

It has been found practical in designing a climatic classification system, to limit the number of weather elements considered, recognizing that such a system dictates that the climate divisions have value for only certain uses. These uses may be to establish the areas suitable for a given crop plant of cultivar. The most useful systems for designating areas having similar climate, from a crop standpoint, have usually limited the elements used in classification to temperature and rainfall (Koppen, 1918; Thornthwaite, 1931; Trewartha, 1968; Griffiths, 1976b).

Delineation of climatic zones has often been based on temperature since it is the most important factor in determining the geographic distribution and the periodic development of crop plants. While temperature is very important, factors other than temperature must be considered in selecting suitable crops or cultivars for a given area. Temperature was found to be the major factor determining the rate and efficiency of plant growth. According to Trewartha (1968), temperatures of $4.4^{\circ} \mathrm{C}$ to $5.6^{\circ} \mathrm{C}\left(40^{\circ} \mathrm{F}\right.$ to $\left.42^{\circ} \mathrm{F}\right)$ were the approximate lower limit at. 
which seeds germinated and seedlings grew. McColm and Dennis (1980) defined the time interval with favorable temperatures for specific kinds of plants as the growing season. They suggested the use of terms such as maximum, optimum, and minimum growth temperature. Several kinds of temperature values are needed for climatological classification. The daily mean has been the most used basic temperature from which monthly and annual values may be computed. The monthly values are the most popular parameters used in climatological classification. This study has used the mean monthly, maximum, and minimum temperatures as the basis for climate classification. The principal objectives were: -a) to classify the land areas of Arizona (United States), and Sonora (Mexico) with some stress on the southern part of Arizona (to latitude $34^{\circ} \mathrm{N}$ ) into growing seasons on the basis of temperature only, and b) to match the climates of selected areas (stations) throughout the world with the growing seasons or climatic regions identified in Arizona and Sonora.

The study of the climates and climatic zones of the area is Important for the following reasons:

1. To assess the climatic resources (temperature) of the border region of the United States and Mexico to help in developing the full potential of the region (Durrenberger and Murrieta, 1978).

2. Problems associated with the most efficient use of water are related to climatic factors, especially temperature.

3. The areas included in the study receive much sunshine, therefore, crop yield potential is very high. 
4. Temperature varies vertically with elevation and a clear understanding of the effect of elevation is important.

5. Introduction of new plants to the study area will be facilitated by an improved understanding of temperature of the area and associated effects on crops and crop cultivars. 


\section{LITERATURE REVIEW}

\section{Basis of Classifying Climate}

The climate of any region is the product of many different climatological factors. For classifying regions into zones, one should consider these factors and their interactions. Critchfield (1974) stated that a complete description of the climate should take into account such parameters as the means, ranges, and diurnal and seasonal variations of temperature, precipitation, sunshine, wind, and other characteristics of the weather. McBoyle (1972) defined the classification as such a powerful filter for ordering data that its use in climate has surpassed the immediate purpose of simplifying unwieldly masses of statistics.

Climatic regions were identified by Critchfield (1974) as areas of the earth's surface over which the combined effects of several factors result in an approximately homogeneous set of climatic conditions. In addition Critchfield (1974) stated the objectives of climatic classification as a) organization of climatic data in such a way that generalization can be made and b) to store information in an orderly manner for easy reference and communication. Fairbridge (1967) listed three steps to be taken in the satisfactory system of classification as 1) organize facts, 2) provide a language for communication, and 3) establish means of identifying boundaries. Critchfield (1974) reported that the interrelated objectives of classification were necessary to bring order to 
large quantities of information, to speed retrieval of information, and to facilitate communication.

To understand these approaches Anderson (1975) differentiated between weather and climate. He defined weather as the specific condition of temperature, humidity, wind, atmospheric pressure, and precipitation in a given place at a given time. He stated that weather is in a constant state of change, while climate describes the typical state of these variables over long periods and often for a wide geographic area. The United States Comittee for Global Atmospheric Research (1975) discussed the differences in variation, variability, and anomaly. They described climatic variation as the difference between climatic states of the same kind such as monthly, seasonal, or yearly climatic variations; climatic variability as the variance between a number of climatic states of the same kind; and climatic anomaly as the deviation of a particular climatic state from the average of a relatively large number of climatic states of the same kind.

The concept of a similarity between climates of various regions was introduced by Koppen toward the end of the last century (Anderson, 1975). The most common factor of climatic classification is the temperature-rainfall criteria (Trewartha, 1968). Trewartha (1968) mentioned that the revised Koppen's system was based on temperature, rainfall, and their seasonal characteristics. He also reported the Thornthwaite system as a method based upon the numerical values of temperature and rainfall. Perrin de Brichambaut and Wallen (1963) classified the near East into main zones, the basic factor for classification being temperature, but rainfall and water balance have been added as 
superimposed factors to show the subdivisions. In three recent climatic classifications by Europeans, the primary groupings were thermic. In their scheme, rainfall differences created subdivisions within the great temperature zones (Trewartha, 1968). Critchfield (1974) adopted broad categories based on the interchange of heat and moisture between the surface and overlying air masses. A unique approach in classifying world desert areas was made by Howe et al. (1968) standing alone in its dependence on the "rain-day" as the key of delineation with thermal subdivisions.

It should be mentioned that, although temperature and rainfall are the main factors of most classifications, other parameters have been used as a basis for classification. Even through the use of temperature and rainfall, climatic category is by no means easy (Brown and Cocheme, 1973). Two places may show the same temperature throughout the year, but have different situations with respect to rainfall. Critchfield (1974) believed that the best that could be achieved would be classification of climate for a specific purpose rather than a general one. According to Fairbridge (1967) there was always overlapping characteristics and transition zones. He suggested relating climatic factors and vegetation as a possible solution. Fairbridge (1967) added that vegetation types reflected the climate of the region by their manner of growth. Hence, vegetation units were used as indicators to classify climates. Another parameter for classification was proposed by Thornthwaite (1948) based upon the concept of potential evapotranspiration. Trewartha (1954) and Critchfield (1974) discussed the genetic 
classification of climate based upon the physical causes of climates, such as the general atmospheric circulation.

\section{Classification Based on Temperature}

Temperature was described by Smith (1956) as the greatest single climatic factor determining the kind of crop that may be grown and favorable seasons for its growth. McColm and Dennis (1980) defined it as the most important single factor determining the growing season for plants. Of all the ingredients that combine to make weather, sun as a source of heat, is the sultan (Anderson, 1975). It was described by McColm (1948), Fairbridge (1967), Sharon (1968), Riordan (1970), Griffiths (1976a), Ruffner and Bair (1977), and Ruffner (1978) as the most important single parameter in meteorology and climatology. Despite its great importance, temperature alone as a basis of climate classification is not completely satisfactory due to interactions of other factors (Fairbridge, 1967). Brown and Cocheme (1973) suggested the use of temperature only as a direct criteria for the comparison of climatic sub-regions. Trewartha (1968) found it practical in designing a climatic classification system to limit the number of weather elements; with the recognition that the system will have value for only certain uses. Perrin de Brichambaut and Wallen (1963) used temperature in their classification because of its great diversity. They said that the basic features of temperature showed much more variation between different areas in the region than those of any other climatic factor. Trewartha (1954) reported that temperature in some cases has served a dual role, since in addition to serving as one basic 
element, it has also been used as an indication of the amount of evaporation.

The first attempt at using temperature as a basis for classification was made by the ancient Greeks (Trewartha, 1954; Fairbridge, 1967). They classified the earth into climatic zones and classified crops according to temperature into seasonal zones. Griffiths (1976b) devised a life-zone classification which showed the temperature regions with elevation and latitude. Fairbridge (1967) reported the isotherm of $18^{\circ} \mathrm{C}\left(64.4^{\circ} \mathrm{F}\right)$ derived by Koppen as the limit related to the survival of many tropical plants. Smith (1956) mentioned the use of temperature in climate classification in "thermal effectiveness" discussed by Thornthwaite (1931). The Trewartha (1968) classification has six main climate groups, five being based on the great thermic zones. In this plan, temperature was used to define five of the climatic subdivisions, each with a strong zonal orientation. Fairbridge (1967) reported a simple temperature classification using the mean annual temperature of $10^{\circ} \mathrm{C}$ $\left(50^{\circ} \mathrm{F}\right)$ and $20^{\circ} \mathrm{C}\left(68^{\circ} \mathrm{F}\right)$. Trewartha (1968) defined temperature efficiency as the effectiveness of temperature in promoting plant growth. He stated that it could be measured by establishing the number of days with temperatures above $4.4^{\circ} \mathrm{C}\left(40^{\circ} \mathrm{F}\right)$. McColm and Dennis (1980) divided Arizona into climatic areas with area designations based, primarily, upon mean monthly temperature.

\section{The Use of Monthly Mean}

Temperature, Maximum and Minimum

The most popular of all climatological parameters is the mean monthly temperature (McColm and Dennis, 1980). It can be derived from 
the maximum and minimum temperature for each month. Fairbridge (1967) suggested using the temperatures for all the days of the month as a base for the maximum, minimum, and mean. The average of the highest and lowest temperatures recorded during each day for the entire month is used to derive the mean monthly temperature (Trewartha, 1954). Trewartha (1968) reported that the frequency distribution of hourly temperatures for a given month may be found empirically from the monthly mean, mean maximum, and mean minimum temperatures. According to Flohn (1969) the monthly means were obtained by taking arithmetic means of the monthly averages of maximum and minimum. Westbrook (1969) took the maximum of $37.8^{\circ} \mathrm{C}\left(100^{\circ} \mathrm{F}\right)$ for his study of desert stations. In addition, Papadakis (1975) showed that the concept of monthly climate (temperature) facilitates the comparison between climates and the study of their agricultural and other potentialities. A similar result was found by Trewartha (1968) when he plotted curves for annual variations of temperature. These curves were fairly smooth when plotted from monthly means. Critchfield (1974) found that the monthly mean derived from mean daily maximum and minimum temperatures gave more reliable results. He found that the average monthly mean, maximum, and minimum enable finer distinctions to be drawn between specific sites. Fairbridge (1967) related monthly mean, maximum, and minimum temperatures and rainfall to the coastal landscapes and divided the world into 14 regions. The mean monthly temperature was also used by Griffiths (1976b) in his classification. Moreover, Perrin de Brichambaut and Wallen (1963), Howe et al. (1968), and McColm and Dennis (1980) used monthly mean, maximum, and minimum temperatures in their classification of climates. 
Effect of Temperature Distribution on Climatic Classification

The major factors affecting temperature in large areas are elevation and latitude (Smith, 1975a). Smith (1956) attributed extremes of temperature in the areas he studied to a wide range of latitudes and to great differences in elevation. According to Brown and Cocheme (1973), surface irregularities, particularly mountain areas, complicate the pattern of the world's climate. Perrin de Brichambaut and Wallen (1963) mentioned that variations in latitude and elevation were associated with changes in temperature that occur throughout the year.

\section{Vertical Distribution of Temperature}

Temperature differences due to different elevations were by far the most Important when comparing places and making climatic area divisions (Brown and Cocheme, 1973; Utaaker, 1980). Classification based on the geographical distribution of air temperature is based on isotherms plotted by elevation or on the bases of temperature reduced to sea level (Critchfield, 1974). Fairbridge (1967) found an increase in the seasonal temperature variation with elevation. However, the rate of decrease of temperature with elevation, referred to as lapse rate, varied in time and space according to Fairbridge (1967). Trewartha (1954) found similar results, but related the variation to time of day, season, and location. Critchfield (1974) added the factors of elevation and latitude as a cause of variation. It was found by Perrin de Brichambaut and Wallen (1963) that in general, the higher the elevation, the smaller is the annual range of temperature. In addition Howe et al. 
(1968) reported that in the desert temperature changed dramatically with increasing elevation above the surface of the land.

The average temperature decrease with elevation (Lapse rate) was found to be $0.65^{\circ} \mathrm{C}$ per 100 meters $\left(3.6^{\circ} \mathrm{F} / 1000\right.$ feet) (Trewartha, $1954), 0.6^{\circ} \mathrm{C}$ per 100 meters $\left(3.5^{\circ} \mathrm{F} / 1000\right.$ feet) for East Africa (Brown and Cocheme, 1973), $6^{\circ} \mathrm{C}$ for each 1000 meters $\left(3.5^{\circ} \mathrm{F} / 1000\right.$ feet) (Critchfield, 1974$), 9.8^{\circ} \mathrm{C}$ for every kilometer $\left(5^{\circ} \mathrm{F} / 1000\right.$ feet) in elevation (Rex, 1969), and 4 to $5^{\circ} \mathrm{C}$ for each 1000 meters (2 to $3^{\circ} \mathrm{F} / 1000$ feet) at lower elevations (Smith, 1963). Brown and Cocheme (1973) reported that the actual value in mountaineous regions differs somewhat because of the influence of the local topography, vegetation, and complex air movements. Because of this variability in the lapse rate, Critchfield (1974) suggested a general reduction of 5 to $6^{\circ} \mathrm{C}$ for every 1000 meters ( 3 to $4^{\circ} \mathrm{F} / 1000$ feet). Brown and Cocheme (1973) believed that if a rough correction of $5^{\circ} \mathrm{C}$ per 1000 meters $\left(3^{\circ} \mathrm{F} / 1000\right.$ feet) were applied to the mean annual temperatures of East Africa, most locations (except along coast) at sea level would have average temperatures between $27^{\circ} \mathrm{C}$ and $30^{\circ} \mathrm{C}\left(80.6\right.$ to $\left.86^{\circ} \mathrm{F}\right)$.

The type of climatic class and the length of the seasons are affected by the vertical distribution of temperature. The diversity in the length of the growing seasons of Arizona results primarily from differences in elevation (McColm and Dennis, 1980). Smith (1956) mentioned that the climate and seasons of Arizona were affected to a great extent by interfering mountain ranges. Climate records of Arizona showed that the length of the growing season is reduced by about 30 days for each increase of 1000 feet (300 meters) in elevation (Smith, 1956; McColm and 
'Dennis, 1980). Smith (1975a) found that the length of the growing season in Britain decreases by about 4-5 days with every 30 meters of elevation. Brown and Cocheme (1973), working in East Africa, reported that the differences introduced within a few miles by elevation and exposure exceeded the entire range for the whole area.

Horizontal (Lateral) Distribution of Temperature

The differences in temperature from place to place are as important as the differences from time to time. Critchield (1974) noted that the effectiveness in heating the earth's surface is largely determined by latitude. Trewartha (1968) and Critchfield (1974) mentioned the general decrease in temperature from the equator toward the poles. Fairbridge (1967) called attention to and described the increase in seasonal variation of temperature with latitude. Critchfield (1974) noted that temperatures decreased from the equator to the poles (from low to hIgh latitude) in both hemispheres, and also that the range of temperatures from low to high increased. In Arizona, part of the explanation for extremes of temperature is based upon great differences in latitude (Smith, 1956). Critchfield (1974) reported that on maps horlzontal distribution of temperatures was commonly shown by means of isotherm lines connecting points with equal temperature values. Griffiths (1976b), on his 1ife-zone classification, correlated temperature and latitude. 


\section{Correlätion between Temperature and Crop Growing Seasons}

In recent years, the critical world situation has focused attention on the necessity for intensive and continuing study of the relationships between weather and crop production. Stallings (1961) Maunder (1968), Smith (1975b), and Baier (1977) studied the impact of weather and climate on crop production and world food supply. Thompson (1975) and Skaar (1980) stated that the planting of crops must take into account the dates when temperatures are likely to fall below the freezing point as well as the length and characteristics of the growing season. In addition, Shaw (1965), and Downs and Hellmers (1976) showed that physical climate components of diurnal and seasonal temperature fluctuations were the controlling factors of plant climate. According to Smith (1956), and Hajek and Gutierrez (1979) temperature was the greatest single factor which determines the kind of crop that may be grown and the seasons which are favorable to its growth.

\section{Temperature-Plant Relations}

Temperature is the major factor determining the rate and efficiency of plant growth (McColm and Dennis, 1980). As mentioned by Shaw (1965), plant development, and the passage of plants through various phases in their advancing seasonal maturity, may be used as indicators of ground level climate. Smith (1975a) mentioned the importance of the frost temperature (below $0^{\circ} \mathrm{C}$ ) in planning the planting and harvesting of crops.

The planting dates and maturation dates of most wheat varieties and corn and sorghum hybrids, when grown in the Great Plains of the 
North American continent, have been found to be delayed by one or two weeks when mean temperatures are reduced 1 to $3^{\circ} \mathrm{C}$ (Baier, 1977). Anderson (1975) mentioned that temperatures in excess of about $6.1^{\circ} \mathrm{C}$ $\left(43^{\circ} \mathrm{F}\right)$ were required for growth by most plants. In pasture plants, a study by Unesco (1958) found that the rate of growth in arid zones declined when temperature increased to over $29.4^{\circ} \mathrm{C}\left(85^{\circ} \mathrm{F}\right)$, and for many plants the amount of growth at $35^{\circ} \mathrm{C}\left(95^{\circ} \mathrm{F}\right)$ was negligible. Griffiths (1976a) called the thresholds for minimum growth ( $\mathrm{T} i$ ), optimum growth (To), and maximum growth (Tu) as the cardinal temperatures which vary with the plant and its developmental stage.

The research work done by Thompson (1975) on weather and technology in the production of grains is typical of the use of multiple regression analysis in relating crop yields to weather variables, mainly temperature and precipitation. To evaluate the impact of simulated changes of temperature and precipitation on yields of winter and spring wheat, Baier (1977) described the Russian work using the monthly mean data. He also mentioned the use of the monthly average temperature with other variables to forecast wheat production in Turkey. In addition, Keulen and Louwerse (1974) and Lomas (1976) mentioned the requirements for plant production of a wheat crop. MicColm and Dennis (1980) reported that the kinds of plants growing in a climatic area, and the kinds that may be successfully introduced to the area, were related to the temperature requirements of the plant and the usual temperature that prevails.

Generally, temperature conditions do not limit the agricultural possibilities, but only give the ranges within which different crop 
varieties have to adapt themselves (Perrin de Brichambaut and Wallen, 1963). A plant species that flourishes in one part of a given climatic zone is likely to be adaptable in other parts of the same zone or in a warmer zone (U.S. Department of Agriculture, 1962). Papadakis (1975) reflected the fact that climates very different from one another may have similar monthly means. The climate zone in which a given plant may survive is not necessarily the zone in which it should be recommended for planting (U.S. Department of Agriculture, 1962).

Temperature and Growing Season

Agricultural production is influenced greatly by the growing season but there are real difficulties in drawing up a wholly acceptable definition of this term. Taylor (1967) has explored some of these difficulties and shown that there is much variation in usage with regard to the threshold temperature of $6^{\circ} \mathrm{C}\left(42.8^{\circ} \mathrm{F}\right)$ which is usually taken as the minimum thermal requirement for any substantial growth in temperature crops. McColm and Dennis (1980) defined the growing season as the time interval with favorable temperature for a specific kind of plant. In addition, according to Smith (1975a) it is most often taken as that seasonal period when the mean temperature exceeds $6^{\circ} \mathrm{C}\left(42.8^{\circ} \mathrm{F}\right)$, although there is disagreement over whether daily, fortnight, or monthly means should be employed, or even whether soil or air temperatures are involved. McColm and Dennis (1980) determined the growing season by the amount of heat, extremes of heat and cold, and variation between day and night temperatures. 
The length of the growing season is a very important parameter. in classification. Smith (1975a) stated that the intensity of the growing period, as opposed to its length, is frequently represented by the accumulation of temperature units above the growth threshold. Smith (1956) and Smith (1975a) calculated the length of the growing season of the United States by the first killing frost (first $32^{\circ} \mathrm{F}$ reading) in the fall and the last $0^{\circ} \mathrm{C}\left(32^{\circ} \mathrm{F}\right)$ in the spring. They defined the length of the growing season as the frost-free period. Papadakis (1975) classified crops into winter types and summer types on the basis of temperature. He established many crop zones for each type.

Smith (1956), and McColm and Dennis (1980) reported that the length of the growing season of Arizona is reduced by about 30 days for each increase of 1,000 feet (300 meters) in elevation. Smith (1956), Smith (1975a), and Jurwitz and Kangieser (1978) discussed the variability of the growing seasons in Arizona and found that they averaged less than three months in some of the higher elevated areas. On the other hand, the lowest desert valleys sometimes have two or three years in succession without freezes. The average duration of the growing season in England and Wales based on a threshold temperature of $5.6^{\circ} \mathrm{C}\left(42^{\circ} \mathrm{F}\right)$ was found by Smith $(1975 \mathrm{a})$ to increase from a minimum 210 days over the Pennines and Welsh uplands to the entire year in the south-western Peninsula. McColm and Dennis (1980) concluded that for any given area crops may be selected and optimum planting dates and probable harvest dates may be determined. 
The Present Climatic Classifications

In classifying climatic data most climatologists have found sharp demarcation between groupings difficult to achieve without considering a non-climatic variable such as elevation or something else that can be measured precisely. Landsperg (1972) mentioned that with few exceptions, there are no sharp boundaries between various climates. The fact that regionalization of climate requires extractions of the basic underlying patterns which may be controlled by one, or all of its elements was stated by McBoyle (1972). Fairbridge (1967) added that although the divisions of the earth surface can be either small or large according to the point of view, the expanse of any area can be determined according to the climatological phenomenon under consideration. In this respect, Landsperg (1972) suggested that in presenting actual classifications, climatologists may have different purposes and for each purpose a classification can be designed. Thisis because climate is too complicated and variable to be classified rigidly (Gentilli, 1952). A general classification for different purposes has been attempted by many climatologists, such as Koppen (1918), Thornthwaite (1931, 1948), Trewartha (1954), Griffiths (1976b), and others.

The Koppen Climate Classification System

Among the most widely known classifications of climate is the system proposed by Koppen (1918). The purpose of this classification as stated by Gentilli (1952), Trewartha (1954), Critchfield (1974), and Rilley and Spolton (1974), is to relate the distribution and type of natural vegetation over the earth to those weather elements which most 
significantly influence the growth of plants, and which at the same time, are most universally measured. These elements are temperature and precipitation. Rilley and Spolton (1974) described the system as a phytogeographical one as it placed paramount importance on plant distribution in identifying climatic regions and helping in the identification of their boundaries.

Koppen's primary classification (1918) was divided into six groups, each designated by a capital letter, ranging from (A) for tropical rainy climate through (H) for undifferentiated high land climates. Trewartha (1954) mentioned that subdivisions that added new letters representing further refinements in temperature and precipitation limit the primary group. These subdivisions were the result of the revision made by Koppen. Critchfield (1974) mentioned the figures $20^{\circ} \mathrm{C}\left(68^{\circ} \mathrm{F}\right)$ and $10^{\circ} \mathrm{C}\left(50^{\circ} \mathrm{F}\right)$ which were adopted by Koppen (1918) in a complete classification based on duration between and below critical values. Trewartha (1954) and Fairbridge (1967) reported that this system was widely used, accepted, and known in nearly all countries. It has been found satisfactory in many respects (Gentilli, 1952). According to Fairbridge (1967) it has the merit of symmetry and simplicity. Trewartha (1954) added the merit of being used as a teaching device because a considerable number of its types coincide reasonably well with certain broad features of the atmospheric circulation and are explained in terms of them. These climatic types were described by Gentilli (1952) as being useful for understanding the climates of large geographical areas. In addition, Trewartha (1954) described this system as a quantitative one that used numerical values for defining 
'the boundaries of climatic groups and types. Fairbridge (1967) considered this system as superior because it included indications of seasonal features and significant details.

The foregoing system has been criticized by Trewartha (1954), Fairbridge (1967), and McBoyle (1972) as being misleading when using the vegetation boundaries. Also, the system is not very satisfactory for higher altitudes. McBoyle (1972) added that the system made no mention of the level of incoming radiation and did not consider differences in the rate of evaporation. According to Trewartha (1954) the system did not agree with the vegetation types found in certain regions. The chief weakness of this classification, as described by Gentilli (1952), was its failure to recognize moisture-balance subdivisions within the wet climates.

Thornthwaite's Classification of Climate

The past half-century has seen the introduction of many alternative classification schemes, most of them based to a large degree on the Koppen's system. Among the better known are the methods proposed by Thornthwaite in 1933 and 1948. Trewartha (1954) argued that the two systems appeared relatively similar, although their author quite rightly insisted that they were fundamentally different. Fairbridge (1967) mentioned that the chief points of departure of this system from the Koppen's system were the use of the expressions, "temperature efficiency and precipitation effectiveness." On the other hand, Trewartha (1954) said that it was like Koppen's system in its dependence on 
' temperature and precipitation. He added that it was based upon the effectiveness of precipitation upon plant growth.

The earlier Thornthwaite classification (1931) following the Koppen's principles assumes that the plant is a meteorological instrument capable of measuring all the integrated climatic elements. Trewartha (1954) described this system as a widely used method that makes use of a complex formula for precipitation effectiveness using monthly mean temperature and monthly rainfall. According to Trewartha (1954), Fairbridge (1967), and Critchfield (1974) the system defined boundaries quantitatively. It was based ultimately on vegetation and it employed combinations of symbols to designate the climatic types. Gentilli (1952) mentioned the advantages of using monthly data and recognition of three moisture-balance subdivisions within the wet climates. Moreover, Trewartha (1954) added that the system permitted more refined analysis of climatic problems related to vegetation and agriculture. Gentilli (1952) was against this system because the formula for moisture balance (precipitation effectiveness) was too complicated for every-day purposes. It was also mentioned by Fairbridge (1967) that the system lacked the indications of seasonal features. Thornthwaite's (1948) classification almost ignores earlier attempts at classification. He introduced the concept of potential evapotranspiration. This new system was based on two climatic factors, a moisture index and a thermal efficiency index. Trewartha (1954) described this system as being developed independently of other geographical features such as vegetation, soils, and land use. Trewartha (1954) 
'reported that the climatic boundaries were determined rationally by comparing precipitation and potential evapotranspiration.

Other Classification Schemes

Following Koppen (1918) and Thornthwaite (1931, 1948), the climatologists tried to find new approaches for classification. Trewartha (1954, 1968) produced a number of modifications of the Koppen's classification. He chose the isotherm $18^{\circ} \mathrm{C}\left(64.4^{\circ} \mathrm{F}\right)$ for the coolest month as the polar limit of tropical climates. Howe et al. (1968), and Rilley and Spolton (1974) described this modification as being useful in defining the climatic regions of the earth in relation to the general wind circulation because it followed some of the vegetation boundaries quite closely.

Another well known classification which is widely used in Europe was made by McBoyle (1972). He employed temperature to classify major climatic groups and precipitation for the subdivisions of the climates. McBoyle (1972), in his classification of Europe, used sixteen variables, mainly a mix of temperature, relative humidity, and precipitation. Many different criteria have been used by other climatologists. Howe et al. (1968) used a plan called thermal regionalization to distribute the world arid and semi-arid homoclimates while Griffiths (1976b) used a trial of classification taking the isotherms $6^{\circ} \mathrm{C}\left(42.8^{\circ} \mathrm{F}\right), 18^{\circ} \mathrm{C}\left(64.4^{\circ} \mathrm{F}\right)$ and the rainfall of $50 \mathrm{~cm}$. Recently, classifications based on heat units and growing degree days were used (Hajek and Gutierrez, 1979 and U.S. Department of Agriculture and U.S. Department of Commerce, 1981). 
MATERIALS AND METHODS

Data for average monthly temperatures from 72 weather stations in Arizona, United States and Sonora, Mexico were used in this study. The selection of these stations for Arizona was based upon their being representative of specific elevations and climate zones, with those in irrigated areas being used when available. Since data for Sonora were limited, selection of these weather stations was based primarily on availability.

A modified terminology for the criterion used by McColm and Dennis (1980) gave principal emphasis to the temperature represented for each station. This terminology was divided into two main parts, depending on the mean maximum, mean, and mean minimum temperatures.

The first part consisted of general features of the classification which are described with numerals as shown in Table 1. Numerals designate the approximate length of the growing season. In this study the growing season for hardy crops was assumed to be favorable at a given location when the mean monthly minimum temperatures were $1.7^{\circ} \mathrm{C}$ $\left(35^{\circ} \mathrm{F}\right)$ or above and mean monthly temperatures were $10^{\circ} \mathrm{C}\left(50^{\circ} \mathrm{F}\right)$ or above (McColm and Dennis, 1980). For warm season crops, a temperature of $5^{\circ} \mathrm{C}$ $\left(41^{\circ} \mathrm{F}\right.$ ) was used as the minimum during the summer (Newman and Wang, 1959). Summer temperatures are those above $15^{\circ} \mathrm{C}\left(59^{\circ} \mathrm{F}\right)$ according to Perrin de Brichambaut and Wallen (1963).

Letters were used to designate the second feature of each climatic area as indicated in Table 2. The letters provide a clue to the 
Table 1. General features of terminology:used in growing season classification (Average monthly temperature).

\begin{tabular}{|c|c|c|c|}
\hline $\begin{array}{l}\text { Climatic Type } \\
\text { Designation }\end{array}$ & Terms & Description & Specifications \\
\hline \multirow[t]{3}{*}{ Year-long } & I & $\begin{array}{l}\text { Extremely } \\
\text { hot }\end{array}$ & $\begin{array}{l}\text { Minimum not less than } 10^{\circ} \mathrm{C} \\
\text { Mean not less than } 18^{\circ} \mathrm{C} \\
\quad \text { all year }\end{array}$ \\
\hline & II & Very hot & $\begin{array}{l}\text { Minimum not less than } 5^{\circ} \mathrm{C} \\
\text { Mean not less than } 13^{\circ} \mathrm{C} \\
\quad \text { all year }\end{array}$ \\
\hline & III & Hot & $\begin{array}{l}\text { Minimum not less than } 1.7^{\circ} \mathrm{C} \\
\text { Mean not less than } 10^{\circ} \mathrm{C} \\
\text { all year }\end{array}$ \\
\hline Hot-moderate & IV & - & $\begin{array}{l}8 \text { months or more but less } \\
\text { than } 12 \\
\text { Minfmum } 1.7^{\circ} \mathrm{C} \text { or above } \\
\text { Mean } 10^{\circ} \mathrm{C} \text { or above }\end{array}$ \\
\hline Moderate & $\mathrm{V}$ & - & $\begin{array}{l}5 \text { months or more but less } \\
\text { than } 8 \\
\text { Minimum } 1.7^{\circ} \mathrm{C} \text { or above } \\
\text { Mean } 10^{\circ} \mathrm{C} \text { or above }\end{array}$ \\
\hline Moderate-cool & VI & - & $\begin{array}{l}2 \frac{1}{2} \text { months or more but less } \\
\text { than } 5 \\
\text { Minimum } 1.7^{\circ} \mathrm{C} \text { or above } \\
\text { Mean } 10^{\circ} \mathrm{C} \text { or above }\end{array}$ \\
\hline Cool & VII & - & $\begin{array}{l}\text { Less than } 2 \frac{1}{2} \text { months } \\
\text { Minimum } 1.7^{\circ} \mathrm{C} \text { or above } \\
\text { Mean } 10^{\circ} \mathrm{C} \text { or above }\end{array}$ \\
\hline
\end{tabular}


Table 2. Extremes of temperature used for classification of climate.

Climate Classification

Based Upon Temperature Extreme

Terms

Specifications

Hot summer growing

A season

2 months or more with mean $25.6^{\circ} \mathrm{C}$ or above

2 months or more with maximum $35.0^{\circ} \mathrm{C}$ or above

Moderate growing

B

Less than 2 months with mean $25.6^{\circ} \mathrm{C}$ or above

season

At least 3 months with minimum $8.9^{\circ} \mathrm{C}$ or above, mean monthly $18.3^{\circ} \mathrm{C}$ or above, and $1 \frac{1}{2}$ months or above with mean $22.2^{\circ} \mathrm{C}$

Cold growing season

C

2 months or more with minimum $8.9^{\circ} \mathrm{C}$ or above and mean $15.6^{\circ} \mathrm{C}$ or above

$1 \frac{1}{2}$ month or less with mean $22.2^{\circ} \mathrm{C}$

Short spring and fall

when occur with I, II, III, IV

2 months or more with minimum below $8.9^{\circ} \mathrm{C}$

2 months or more with mean

Summer suitable for below $15.6^{\circ} \mathrm{C}$

cold tolerant crops

when appear with VI

Widespread between day

$\mathbf{w}$

Range of $10^{\circ} \mathrm{C}$ bet. maximum and minimum during the growing season 
amount of heat that usually occurs during the growing season. Most plants require temperatures above $6^{\circ} \mathrm{C}\left(43^{\circ} \mathrm{F}\right)$ for normal growth (Anderson, 1975). Temperatures above $35^{\circ} \mathrm{C}\left(95^{\circ} \mathrm{F}\right)$ greatly reduce or terminate growth for most plants (UNESCO, 1958). Griffiths (1976a), using warm-season plants, found that they responded favorably to minimum temperatures of $15-18^{\circ} \mathrm{C}\left(59-65^{\circ} \mathrm{F}\right)$ and mean temperatures of $25-31^{\circ} \mathrm{C}$ $\left(77-88^{\circ} \mathrm{F}\right)$. In this study, temperatures of $15.6^{\circ} \mathrm{C}\left(60^{\circ} \mathrm{F}\right), 18.3^{\circ} \mathrm{C}$ $\left(65^{\circ} \mathrm{F}\right)$ and $25.6^{\circ} \mathrm{C}\left(78^{\circ} \mathrm{F}\right)$ were used as means for climatic classification (Table 2).

Data collected from weather stations were sorted according to the criteria established in Tables 1 and 2. Matching the climates of selected stations from locations outside the study area was accomplished by comparing maximum, mean, and minimum temperature data for these stations with similar data for representative Arizona and Sonora sites. 
RESULTS AND DISCUSSION

Twenty different climate classifications for Arizona, United States and Sonora, Mexico were developed as a result of the study of mean maximum, mean, and mean minimum temperatures as described in the Materials and Methods chapter. A complete list of the weather stations and their climatic classification is included in the Appendix (Table AlA2). These climatic classes are illustrated in Figure 1 which is drawn with the aid of an opaque projector, using temperature data in relation to elevation. The classes shown in Figure 1 represent the different growing seasons of the area.

Examples of a year-long, extremely hot growing season climate are shown in Table 3 and Figure 2. Cotton (Gossypium hirsutum L. and Gossypium barbadense L.) and sorghum (Sorghum vulgare Pers.) are adapted to the long growing season. In these areas two crops of sorghum can be grown or sorghum may follow small grain in the same year. Other heat tolerant crops such as watermelon (Citrullus Iunatus L.), sweet potato (Ipomoea batatus (I) Lam.), okra (Hibiscus esculentus $L_{.}$), and eggplant (Solanum melongena var. esculentum L.), may also be grown. Hardy agronomic crops like alfalfa (Medicago sativa L.), sugar beets (Beta vulgaris L.), winter wheat and spring wheat (Triticum vulgare Vill.) can be grown during the fall. This type of climate is characterized by a year-long growing season with a wide spread between day and night temperature (class Iw) and with a very hot summer (class IAw). 
Figure 1. Growing seasons of Arizona, United States and Sonora, Mexico. 


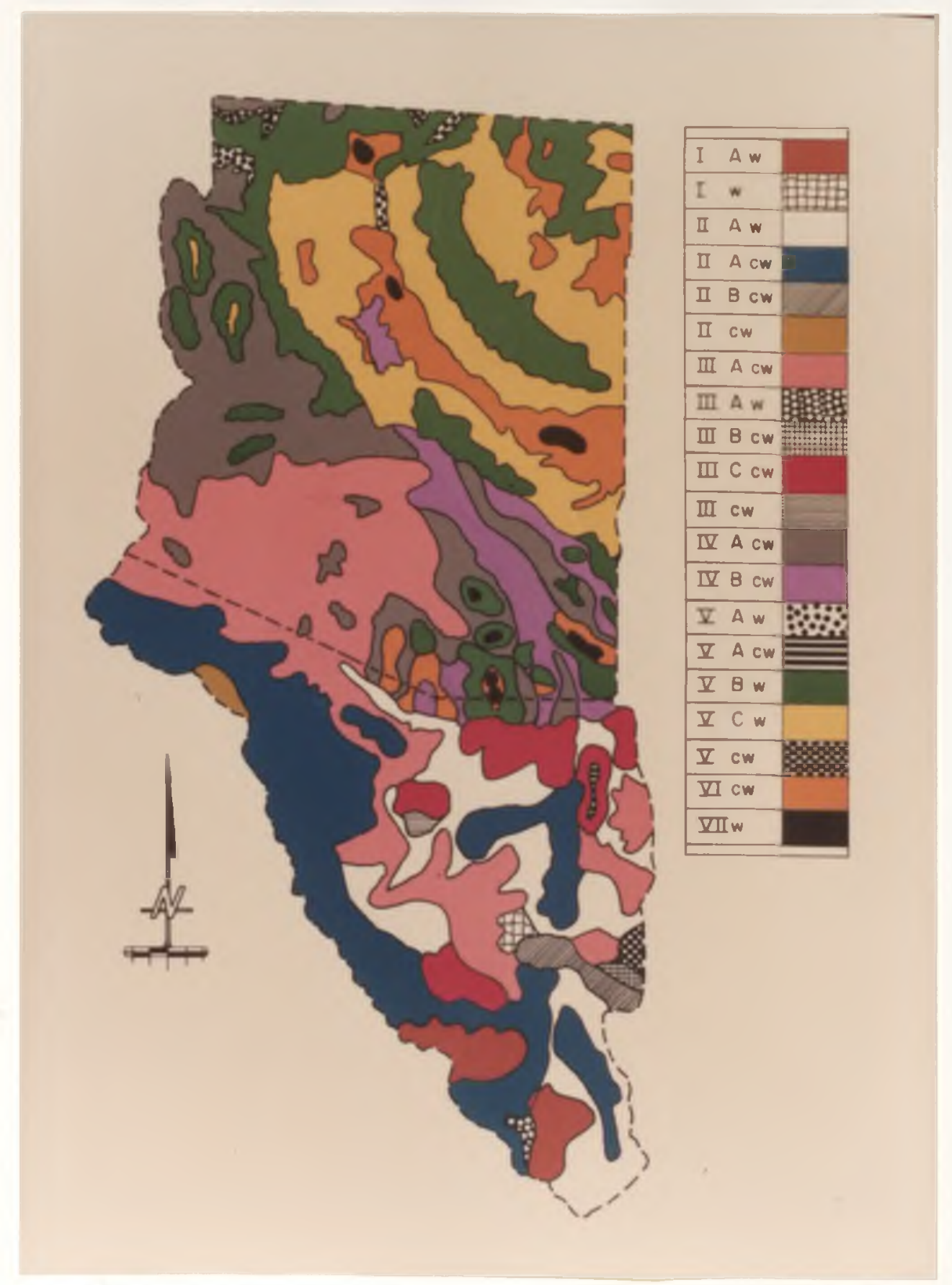


Table 3. Climatic data for locations representing year-long, extremely hot growing season climate.

\begin{tabular}{|c|c|c|c|c|c|c|c|c|c|c|c|c|c|c|c|}
\hline \multirow[b]{2}{*}{ Class } & \multirow[b]{2}{*}{ Location } & \multirow[t]{2}{*}{$\cdots$} & \multicolumn{13}{|c|}{ Average sonthly Temperatures ${ }^{\circ} \mathrm{c}=$} \\
\hline & & & $\bar{J}$ & $\bar{F}$ & $\bar{M}$ & A & $M$ & $\mathrm{~J}$ & $\mathrm{~J}$ & A & $\mathbf{s}$ & 0 & $\bar{N}$ & D & Annual \\
\hline \multirow[t]{3}{*}{ IAw } & \multirow{3}{*}{$\begin{array}{l}\text { Guaymas, Sonora, } \\
\text { Mexico } \\
\text { elv. } 8 \mathrm{M} \\
\text { Lat. } 27^{\circ} \mathrm{S} 55^{\prime} \mathrm{N} \\
\text { Long. } 110^{\circ} 54^{\prime} \mathrm{W}\end{array}$} & Maximum & 23.5 & 24.6 & 26.2. & 28.8 & 32.0 & 34.0 & 35.4 & 35.4 & 35.0 & 32.4 & 27.6 & 23.8 & 29.9 \\
\hline & & Mean & 18.3 & 19.3 & 20.7 & 23.2 & 26.6 & 29.0 & 31.1 & 31.1 & 30.6 & 27.5 & 22.4 & 19.1 & 25.1 \\
\hline & & Menimum & 13.5 & 14.4 & 15.6 & 17.9 & 20.8 & 24.7 & 27.5 & 27.4 & 26.9 & 22.8 & 17.8 & 14.5 & 20.3 \\
\hline \multirow[t]{3}{*}{ Iw } & \multirow{3}{*}{$\begin{array}{l}\text { Nacor1 Grande, } \\
\text { Villa Pesquelra, } \\
\text { Sonora, Mexico } \\
\text { elv. } 634 \mathrm{M} \\
\text { Lat. } 29004^{\prime} \mathrm{N} \\
\text { Long. } 110^{\circ} 03^{\prime} \mathrm{H}\end{array}$} & Maximum & 19.8 & 21.7 & 24.2 & 28.0 & 31.2 & 34.9 & 32.9 & 32.6 & 32.5 & 29.3 & 24.7 & 21.7 & 27.7 \\
\hline & & Mean & 16.8 & 17.9 & 20.9 & 24.5 & 27.3 & 30.8 & 29.7 & 29.2 & 28.9 & 25.8 & 21.4 & 18.4 & 24.2 \\
\hline & & Minimum & 13.8 & 14.1 & 17.6 & 21.0 & 23.4 & 26.7 & 26.5 & 25.9 & 25.3 & 22.4 & 18.1 & 15.1 & 20.8 \\
\hline
\end{tabular}

I/Servico Meteorologico Nacional (1976). 


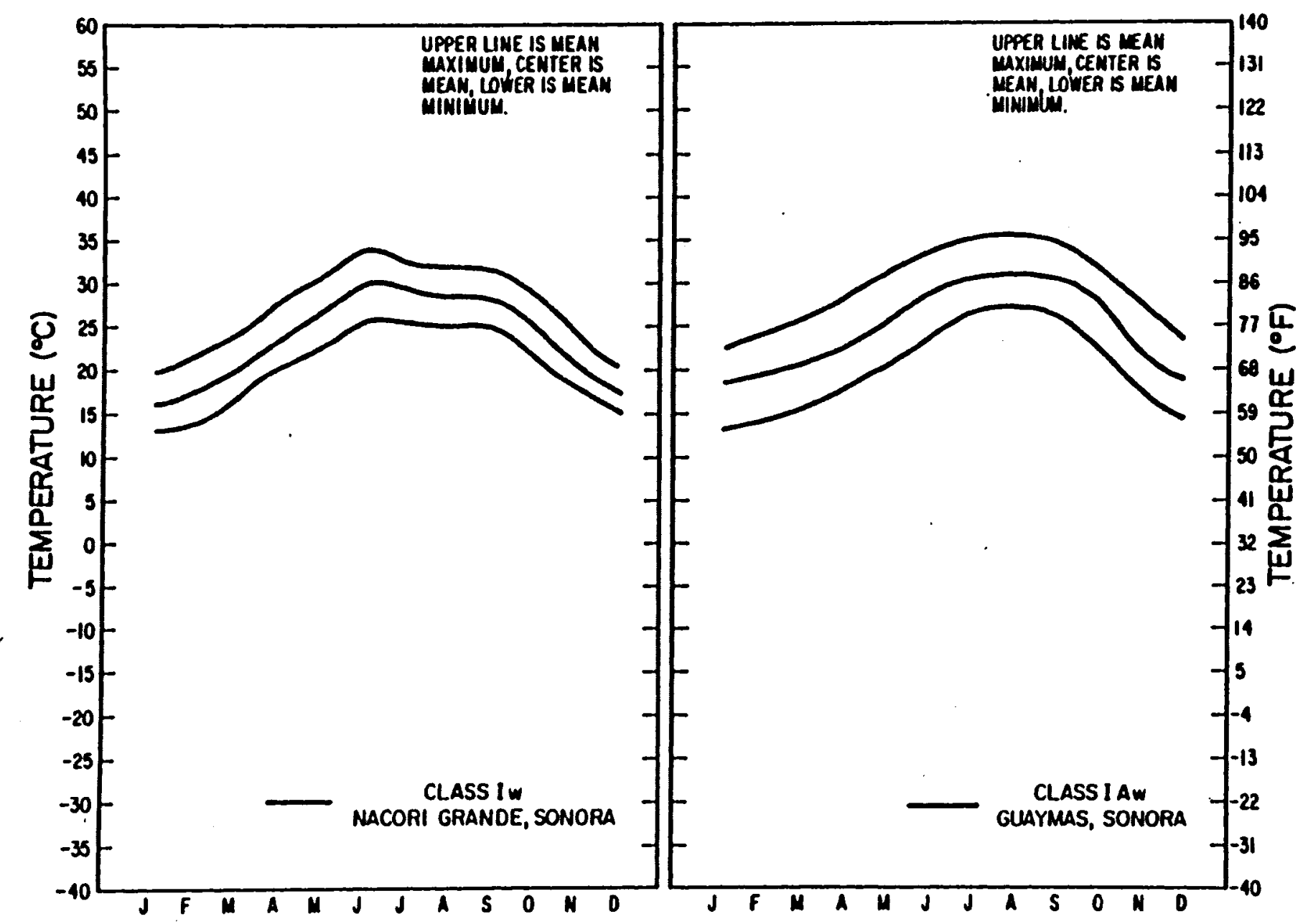

Figure 2. Maximum, mean, and minimum temperature for locations representing year-1ong, extremely hot growing season climate. 
Data presented in Table 4, Figures 3 and 4 illustrate the yearlong, very hot growing season climate. For better understanding, this type of climate has been divided into sub-groups in this study. These are class IIAw with a hot sumer growing season, class IIAcw with a hot summer and short spring and fall, class IIBCw with a moderate season and short spring and fall, and class IIcw for growing seasons with short spring and fall. In each of these four categories heat tolerant crops like cotton, sorghum, watermelon, sweet potato, okra, and eggplant can be grown. Hardy agronomic crops as alfalfa, sugarbeets, winter wheat and spring wheat are well suited to classes IIBCw and IIcw or during the fall in classes IIAw and IIAcw.

The year-long, hot growing season climate has been divided into four sub-groups as shown in Table 5 and Figures 5, 6, and 7. Double cropping is often practised in the yearlong, hot growing season specially in class IIIACw and spring and fall vegetable crops can also be grown. Citrus is adapted to class IIIAcw. Cold tolerant crops like small grains, sugarbeets, safflower (Carthamus tinctorius L.), lettuce (Lactuca sativa L.), spinach (Spinacia oleracea), and hardy grasses can be planted in classes IIIBCw, IIICCW, and IIICw, and to some extent in classes IIIACW and IIIAw when planting is in the fall. Crops like sugarbeets and carrots (Daucus carota var. sativa L.) may be planted in late August so as to mature before cold weather. During summer, heat tolerant crops as cotton, sorghum, watermelon, eggplants may also be grown.

Differences between the three groups classified as having yearlong growing season are small. Many different kinds of plants can be 
Table 4. Climatic data for locations representing year-long, very hot growing season c1imate.

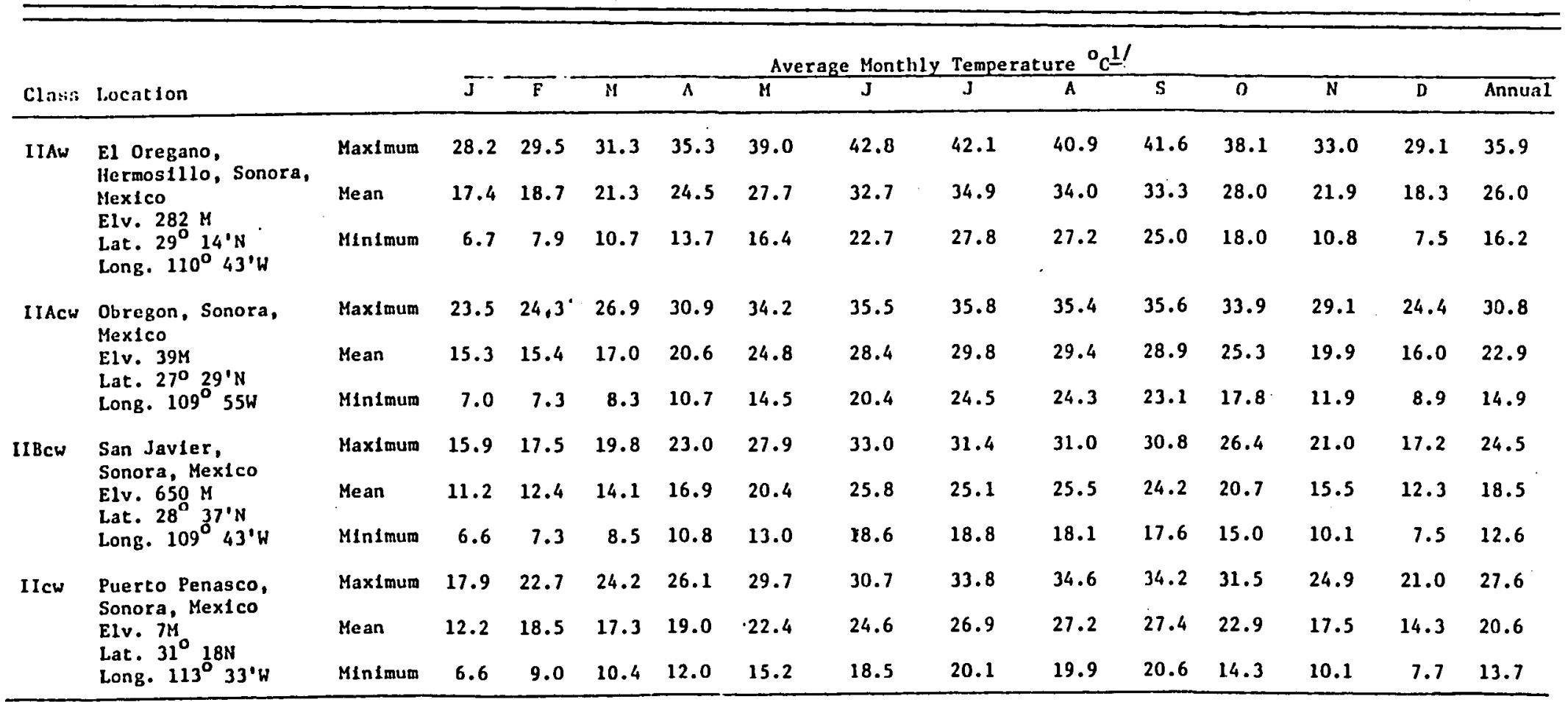

1/Servico Meteorologico Nacional, 1976. 

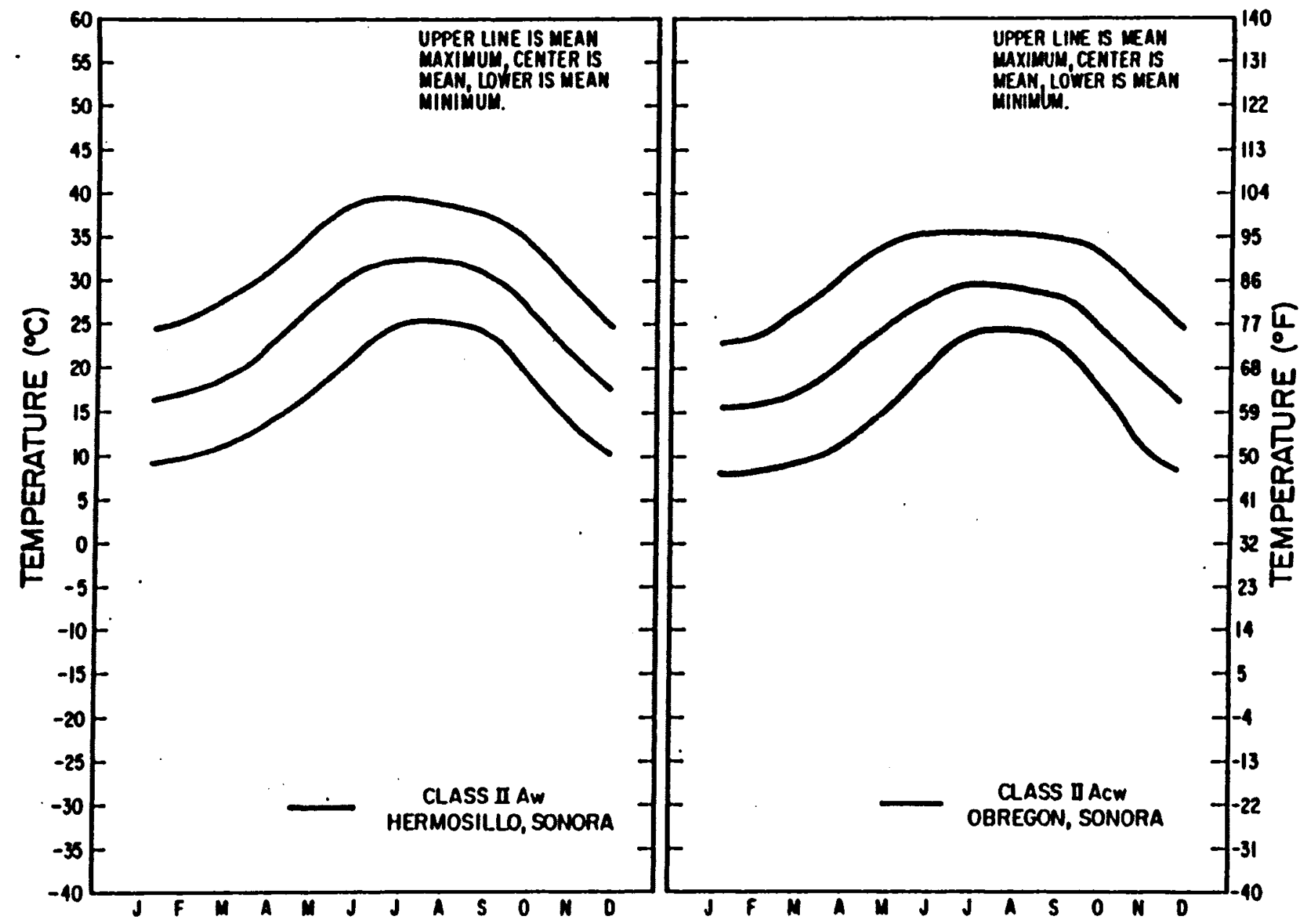

Figure 3. Maximum, mean, and minimum temperatures for locations representing year-long, very hot climate with hot summer. 


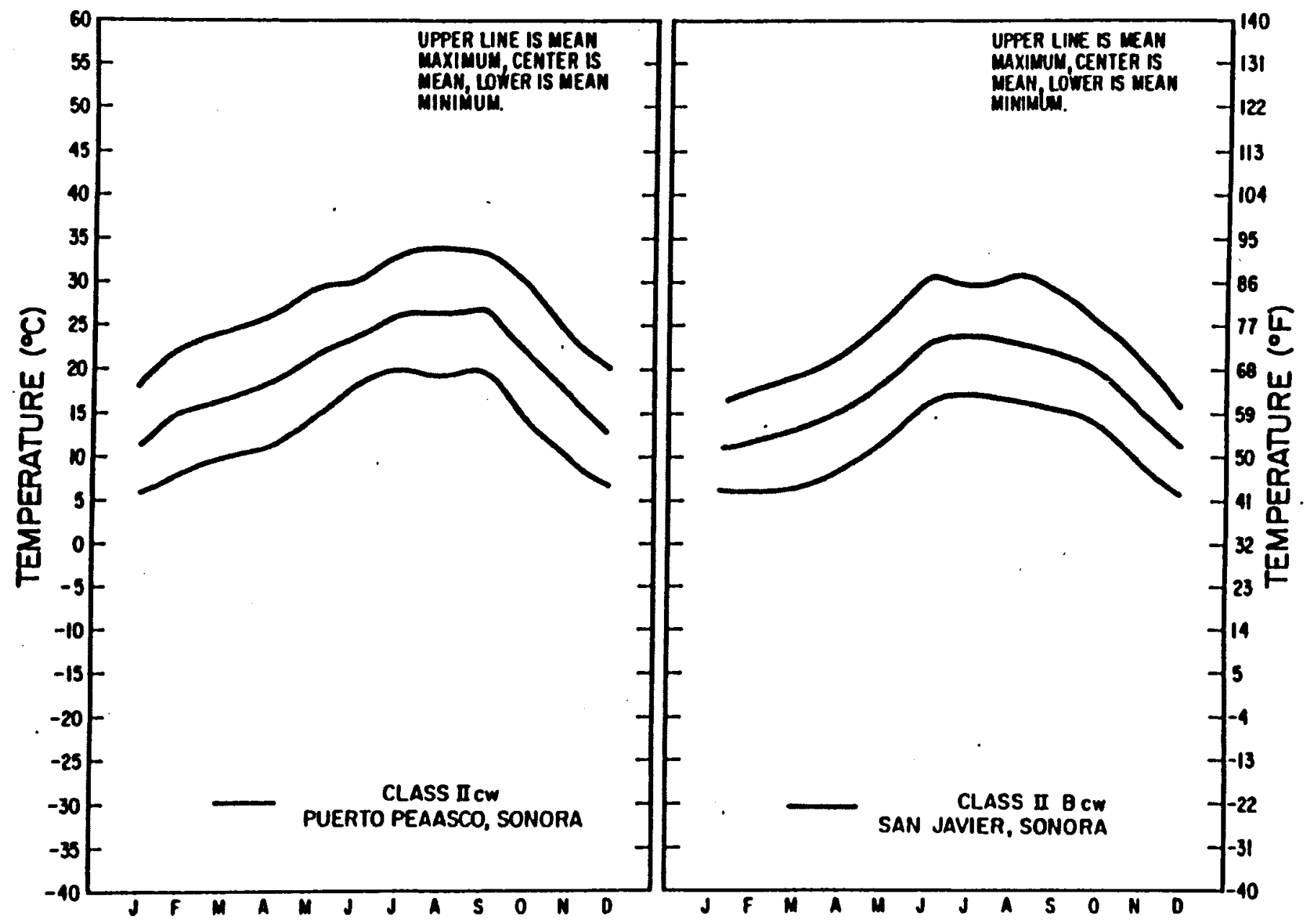

Figure 4. Maximum, mean, minimum temperatures for locations representing year-long, very hot climate with moderate summer. 
Table 5. Climatic data for locations representing year-long, hot growing season climate.

\begin{tabular}{|c|c|c|c|c|c|c|c|c|c|c|c|c|c|c|c|}
\hline \multirow[b]{2}{*}{ Class } & \multirow[b]{2}{*}{ Location } & & \multirow[b]{2}{*}{$\overline{\mathbf{J}}$} & \multirow{2}{*}{\multicolumn{12}{|c|}{$\frac{\text { Average Monthly Temperatures }}{3}{ }^{\circ} \mathrm{C}^{\mathrm{l}} \mathrm{l}$}} \\
\hline & & & & $F$ & $M$ & $\bar{A}$ & & $\mathrm{~J}$ & $J$ & A & $\mathbf{s}$ & 0 & $\bar{N}$ & D & $\overline{\text { Annual }}$ \\
\hline \multirow{3}{*}{ II IAcW } & \multirow{3}{*}{$\begin{array}{l}\text { Yuma, Arizona } a^{1 /} \\
\text { Elv. } 422^{\mathrm{M}} \\
\text { Lat. } 32^{\circ} \cdot 40^{\prime} \mathrm{N} \\
\text { Long. } 114^{\circ} 36^{\prime} \mathrm{W}\end{array}$} & Maximum & 19.2 & 22.2 & 25.6 & 30.7 & 33.9 & 39.8 & 41.1 & 40.0 & 39.5 & 32.5 & 24.4 & 20.6 & 31.2 \\
\hline & & Mean & 12.4 & 14.8 & 17.9 & 22.9 & 25.4 & 30.6 & 33.3 & 32.6 & 31.3 & 24.2 & 16.7 & 13.7 & 23.3 \\
\hline & & Minimum & 5.6 & 7.3 & 10.2 & 15.1 & 17.8 & 21.5 & 25.4 & 25.2 & 23.0 & 16.0 & 9.0 & 6.8 & 15.4 \\
\hline \multirow{3}{*}{ IIIACW } & \multirow{3}{*}{$\begin{array}{l}\text { Flex Gomez, } \frac{2}{} \\
\text { Sonora, Mexico } \\
\text { Elv. } 614 \mathrm{M} \\
\text { Lat. } 29^{\circ} \text { SON } \\
\text { Long. } 111^{\circ} 31^{\prime} \mathrm{W}\end{array}$} & Maximum & 21.8 & 22.5 & 24.7 & 28.2 & 34.3 & 36.1 & 37.4 & 35.9 & 33.6 & 32.2 & 25.9 & 22.0 & 29.6 \\
\hline & & Mean & 12.8 & 13.7 & 15.6 & 18.6 & 22.4 & 26.0 & 28.6 & 27.0 & 25.6 & 23.8 & 15.2 & 12.1 & 20.1 \\
\hline & & Minimum & 3.7 & 4.9 & 6.4 & 8.9 & 10.4 & 15.9 & 19.8 & 18.1 & 17.6 & 15.4 & 4.4 & 2.1 & 10.6 \\
\hline \multirow{3}{*}{ I I I AW } & \multirow{3}{*}{$\begin{array}{l}\text { Vicam, Sonora } 2 / \\
\text { Mexico } \\
\text { Elv. } 46.8511 \\
\text { Lat. } 27^{\circ} 09^{\prime} \mathrm{N} \\
\text { Long. } 110^{\circ} 17^{\prime} \mathrm{W}\end{array}$} & Maximum & 25.6 & 26.9 & 29.3 & 32.5 & 35.8 & 38.1 & 38.7 & 37.8 & 37.8 & 35.4 & 30.5 & 26.1 & 32.9 \\
\hline & & Mean & 15.0 & 16.3 & 18.4 & 21.2 & 24.9 & 29.4 & 31.8 & 31.1 & 30.2 & 25.8 & 19.9 & 15.7 & 23.3 \\
\hline & & Minimum & 4.4 & 5.6 & 7.4 & 9.9 & 13.9 & 20.7 & 24.9 & 24.3 & 22.5 & 16.1 & 9.3 & 5.3 & 13.7 \\
\hline \multirow[t]{3}{*}{ IIIBCW } & \multirow{3}{*}{$\begin{array}{l}\text { Mulatas, Sahuaripa } 2 \text { / } \\
\text { Sonora, Mexico } \\
\text { Elv. } 1165 \mathrm{M} \\
\text { Lat. } 28^{\circ} 38 \mathrm{~J} \\
\text { Long. } 108^{\circ} 45^{\mathrm{I}} \mathrm{W}\end{array}$} & Maximum & 20.1 & 22.4 & 24.9 & 27.6 & 30.5 & 34.4 & 31.9 & 31.3 & 31.8 & 29.9 & 24.8 & 20.7 & 27.5 \\
\hline & & Mean & 11.9 & 13.7 & 15.9 & 19.2 & $22.3^{9}$ & 26.5 & 25.1 & 24.5 & 24.0 & 21.0 & 15.9 & 12.4 & 19.3 \\
\hline & & Minimum & 3.7 & 5.0 & 7.0 & 10.8 & 14.2 & 18.6 & 18.4 & 17.7 & 16.2 & 12.1 & 7.1 & 4.2 & 11.2 \\
\hline \multirow{3}{*}{ IIICCW } & \multirow{3}{*}{$\begin{array}{l}\text { Cananea, Sonora- } \\
\text { Mexico } \\
\text { Elv. } 1585 \mathrm{M} \\
\text { Lat. } 30^{\circ} 58^{\circ} \mathrm{N} \\
\text { Long. } 110^{\circ} 17 \mathrm{~W}\end{array}$} & Maximum & 14.4 & 16.0 & 17.1 & 22.6 & 26.6 & 31.1 & 30.2 & 29.2 & 27.6 & 24.1 & 18.3 & 14.5 & 22.7 \\
\hline & & Mean & 8.4 & 9.8 & 10.7 & 15.4 & 19.2 & 23.9 & 23.8 & 23.2 & 21.5 & 17.7 & 12.5 & 8.8 & 16.3 \\
\hline & & Minimum & 2.3 & 3.6 & 4.3 & 8.1 & 11.8 & 16.6 & 17.3 & 17.2 & 15.3 & 11.3 & 6.7 & 3.1 & 9.8 \\
\hline \multirow{3}{*}{ II I I w } & \multirow{3}{*}{$\begin{array}{l}\text { Santa Ana } 2 / \\
\text { Sonora, Mexico } \\
\text { Elv. } 6868^{\circ} \\
\text { Lat. } 30^{\circ} 33^{\prime} \mathrm{N} \\
\text { Long. } 111^{\circ} 08^{\prime} \mathrm{W}\end{array}$} & Maximum & 19.1 & 20.4 & 22.9 & 27.3 & 31.6 & 36.5 & 34.5 & 34.2 & 33.1 & 29.9 & 23.8 & 19.9 & 27.7 \\
\hline & & Mean & 10.6 & 11.5 & 13.9 & 17.3 & 21.1 & 26.4 & 28.0 & 27.5 & 25.5 & 20.9 & 14.7 & 11.3 & 19.0 \\
\hline & & Mininum & 2.2 & & 4.9 & 7.4 & 10.7 & 16.4 & 21.5 & 20.9 & 17.9 & 12.0 & 5.6 & 2.8 & 10.4 \\
\hline
\end{tabular}

$\underline{1}$ /U.S. Weather Bureau, 1980. 2/Servicio Meteorologico Nacional, 1976. 


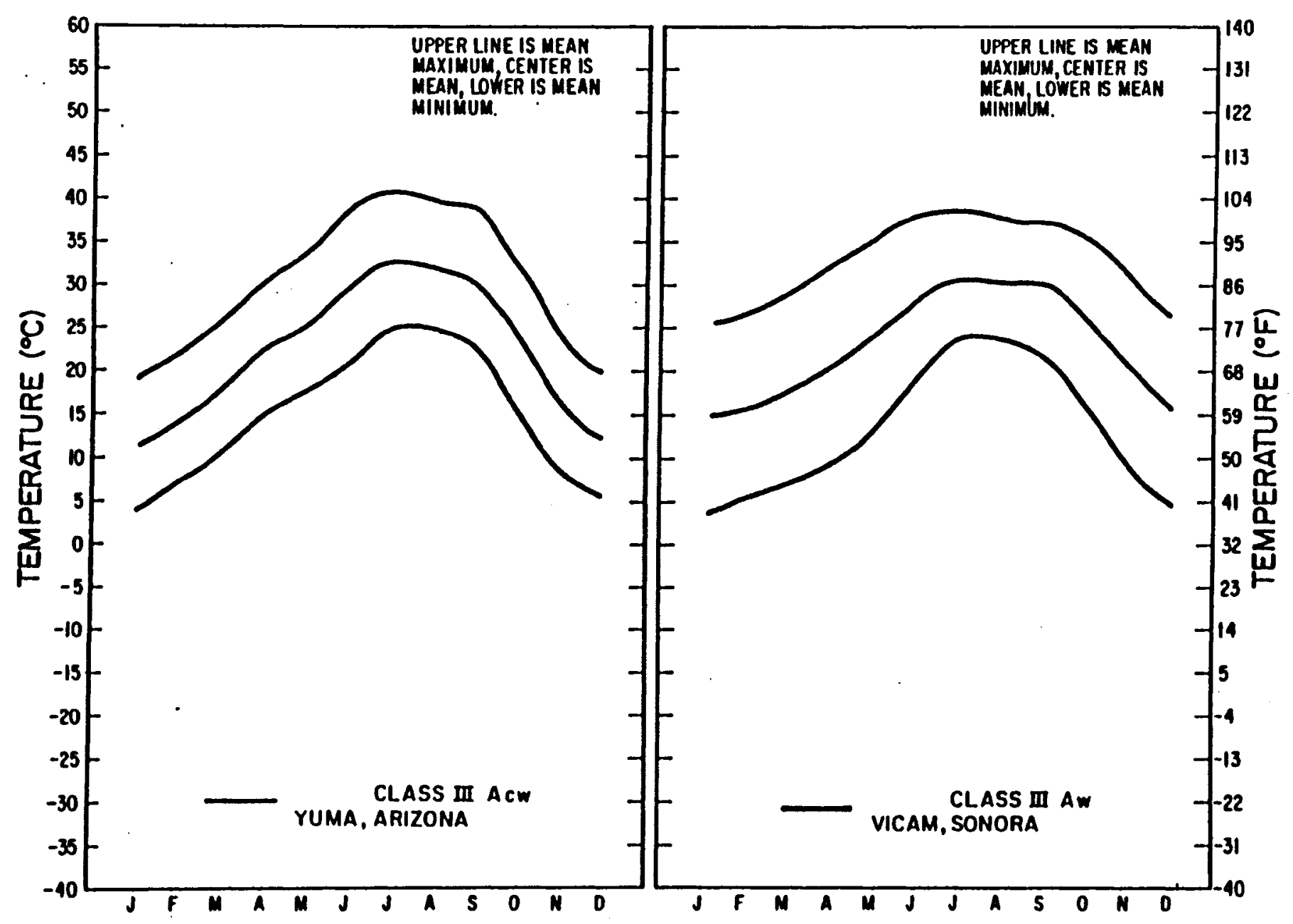

Figure 5. Maximum, mean, and minimum temperatures for locations representing year-long hot climate with hot summer. 


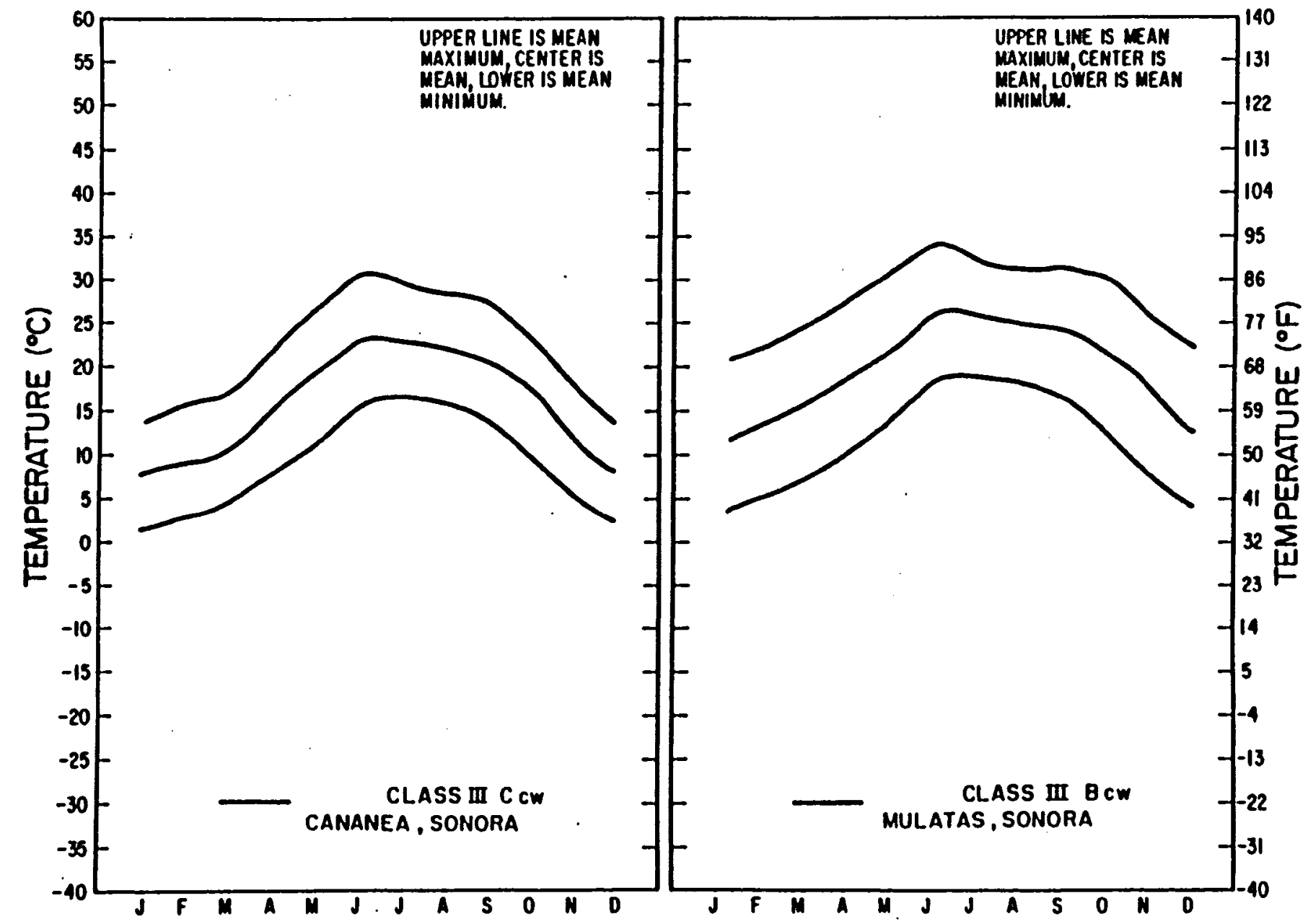

Figure 6. Maximum, mean, and minimum temperatures for locations representing year-long moderate cold growing season climate. 


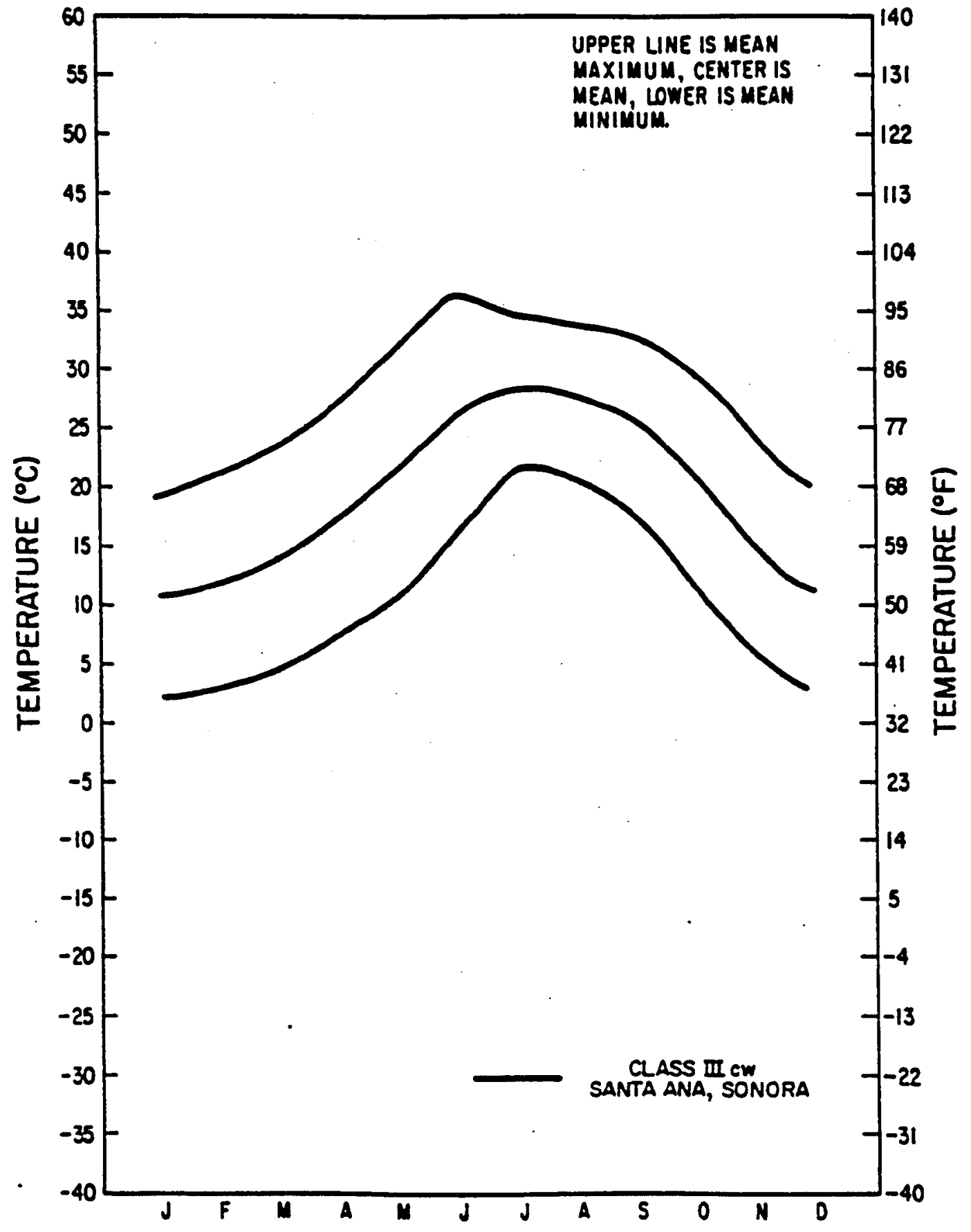

Figure 7. Maximum, mean, and minimum temperatures for a location representing year-long cold growing season climate. 
grown, if the proper date of planting is selected. This difference is . clearly shown in Figures $8,9,10,11$, and 12. Sometimes the maximum mean temperature of class II or III may exceed that of class I (Figures 8, 9) for short periods, but the overall average temperature of class I is higher than that for areas given the classes II or III. Designation classes with the letter A have either an overall average annual temperature greater than B (Figure 10) and C (Figure 12), or a summer temperature higher than that of B or C (Figure 12).

The hot-moderate temperature climate as used in this study has a growing season extending from 8 to 12 months. This climate classification has two sub-groups (Table 6 and Figure 13). Areas having a climatic classification IVAcw (hot summer and cool winter) are suitable for small grains, sugarbeets, alfalfa, safflower, ryegrass (Lollum multiflorum Lam.) and other cold tolerant crops. There is a relatively short spring and fall for hardy crops like turnips (Brassica rapa L.), brocolli (Brassica oleracea var. botryt1s L.), or lettuce (Lactuca sativa L.), in this area. The climatic area classes IVBCw has a moderate summer temperature and is suited to tender crops as corn (Zea mays, L.), beans (Phaseolus vulgaris L.), tomatoes (Lycopersicon esculentum Mill.), and squash (Cucurbita pepo L.). Hardy forage crops like alfalfa are adapted and sugarbeets planted in the spring, for fall harvest, are also possible. Both classes IVACw and IVBCw have a frost period and although class IVBCw has a mean minimum temperature higher than class IVACW for the entire year (Figure 14), class IVAcw has the highest mean maximum and mean temperature. 


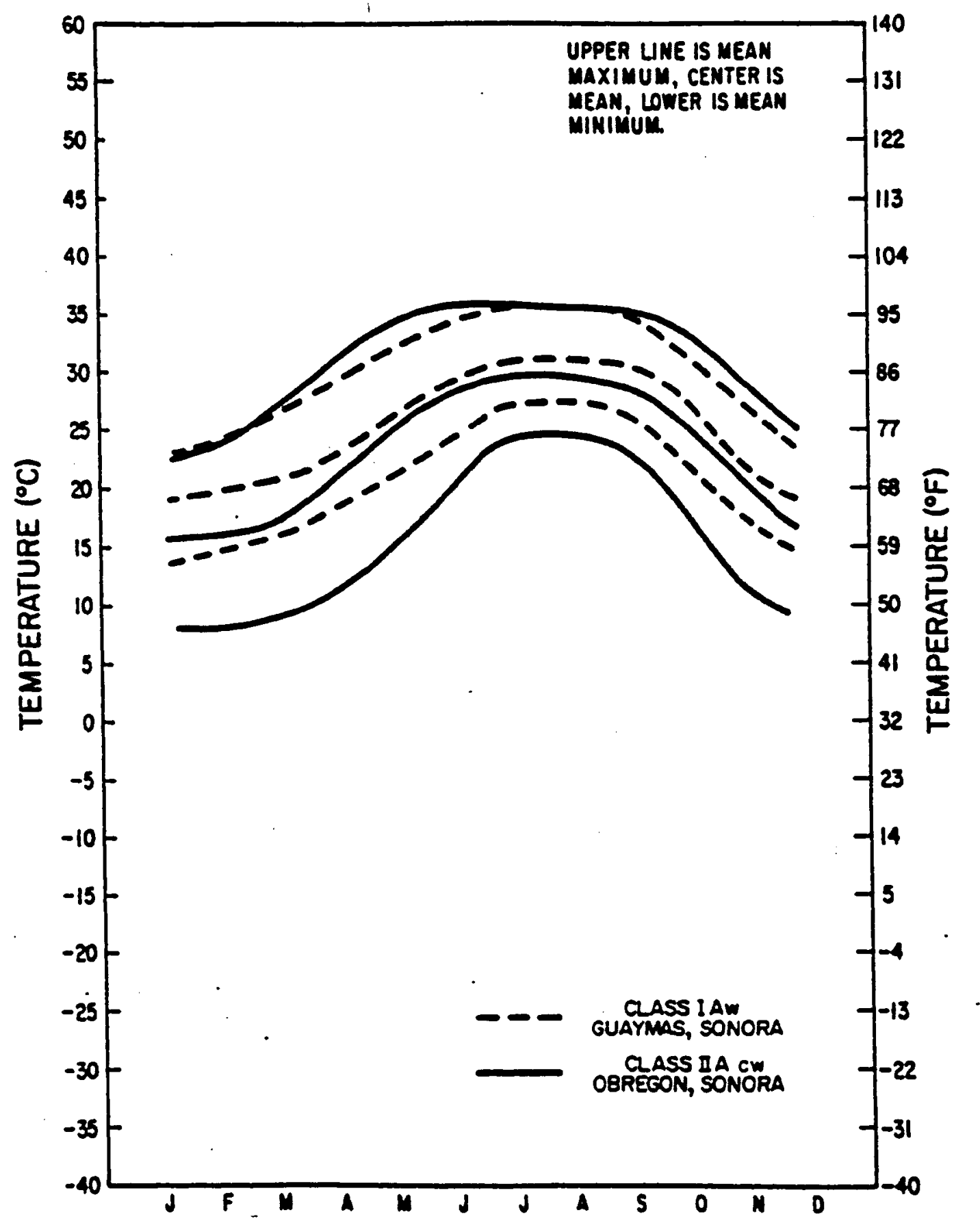

Figure 8. Graph comparing maximum, mean, and minimum temperatures of extremely hot (IAw) and very hot (IIAcw) year-long growing seasons. 


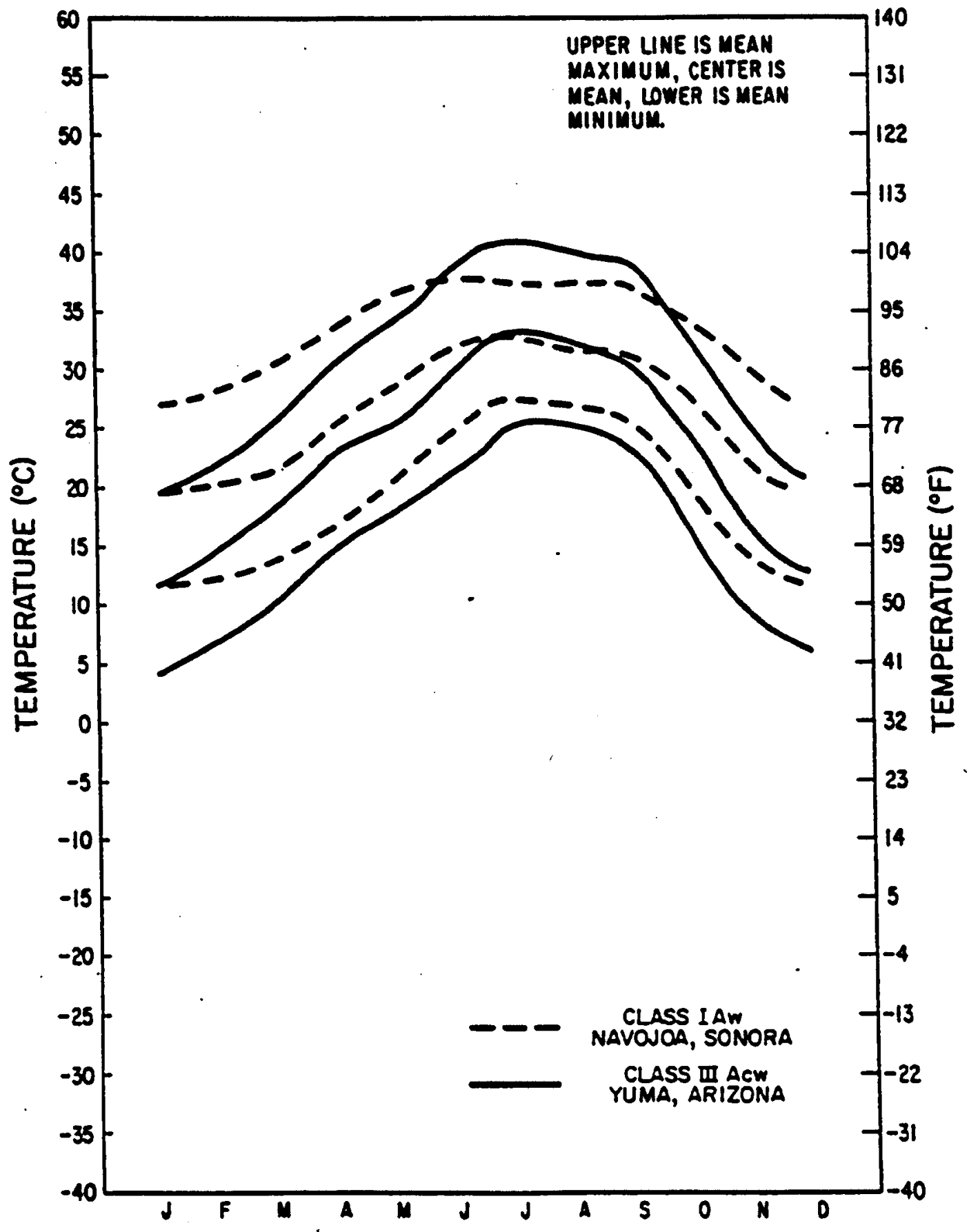

Figure 9. Graph comparing maximum, mean and minimum temperatures of extremely hot (IAw) and hot (IIIACw) year-long growing seasons. 


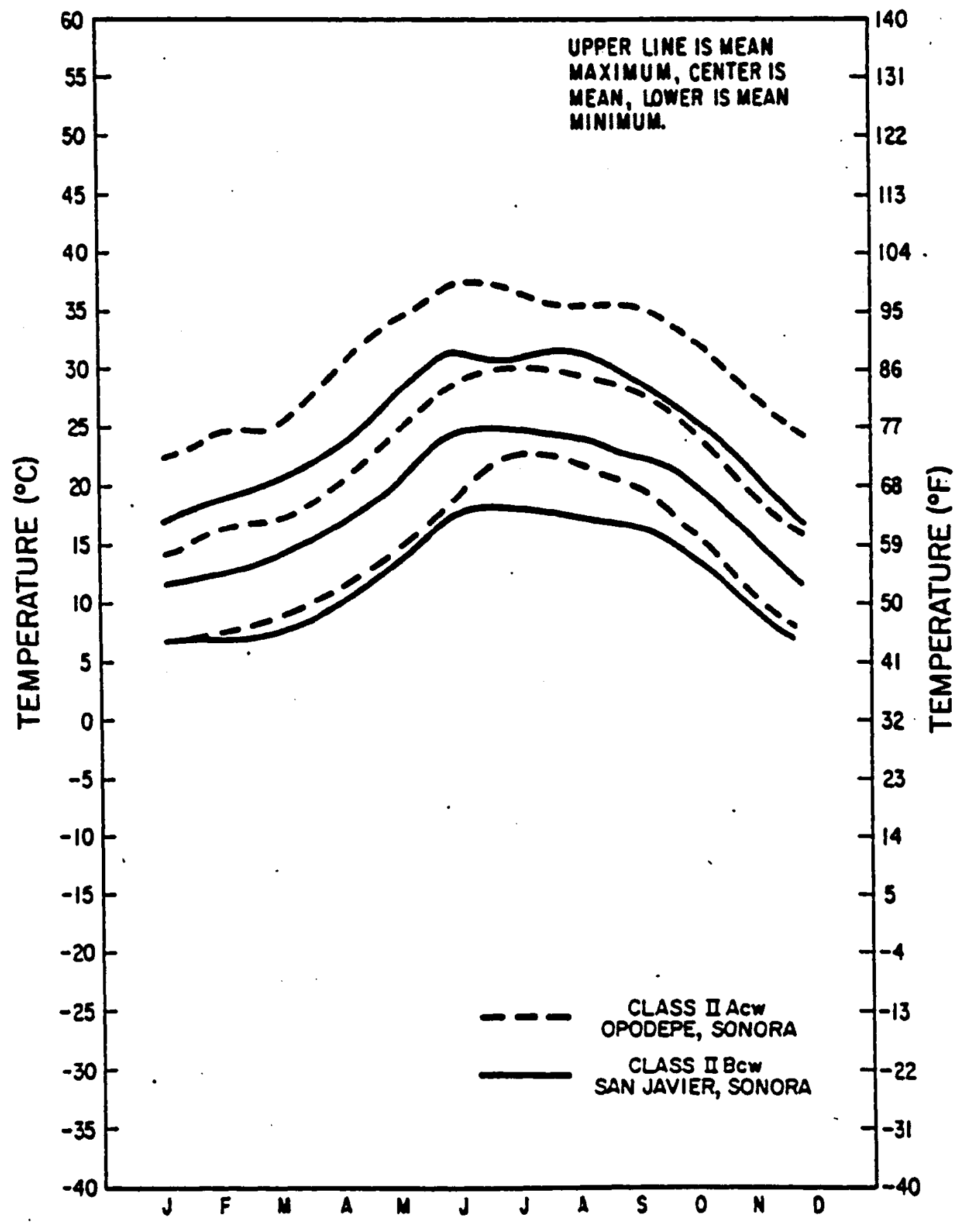

Figure 10. Graph comparing maximum, mean, and minimum temperatures of hot summer (IIACW) and moderate summer (IIBCW) yearlong, very hot growing seasons. 


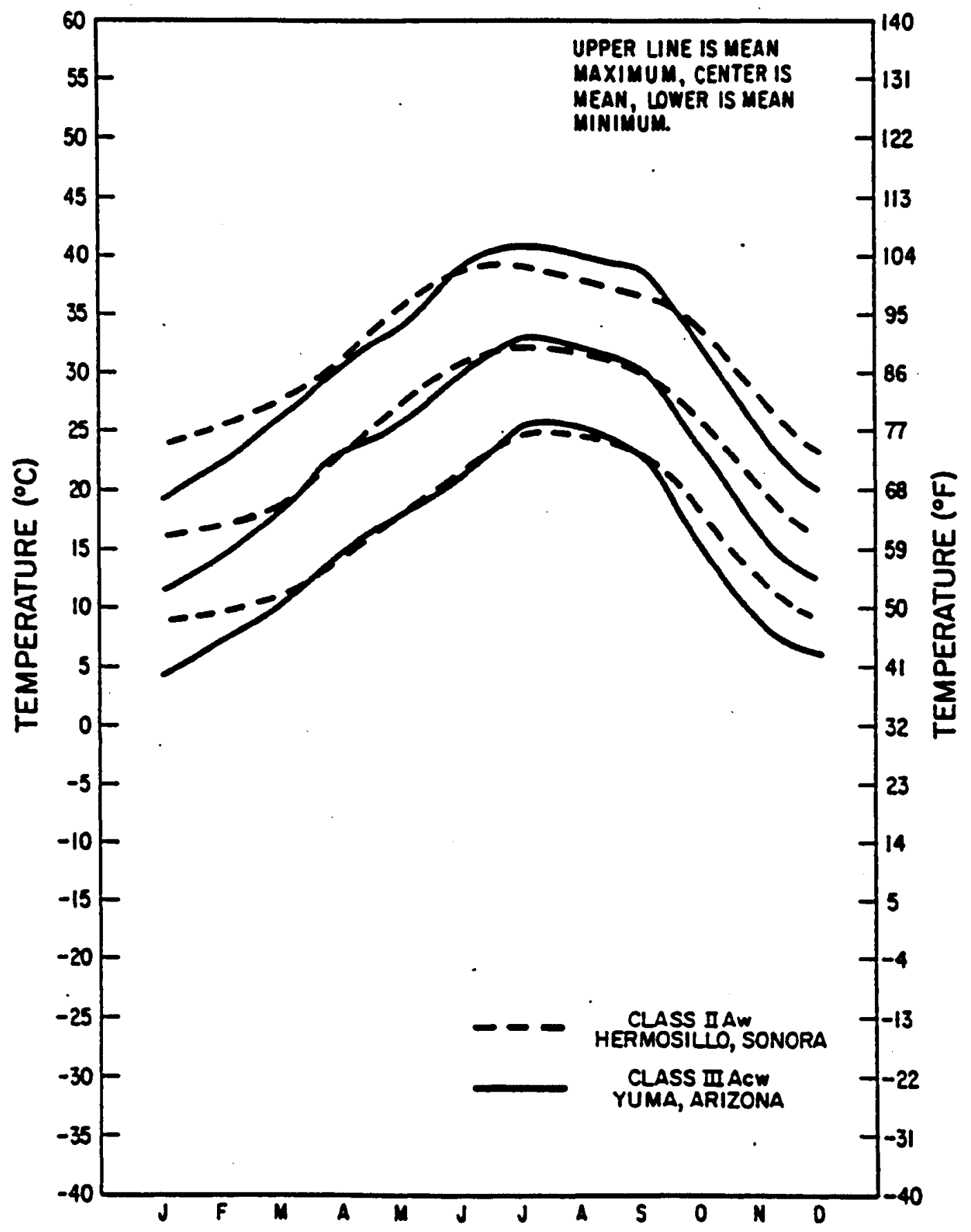

Figure 11. Graph comparing maximum, mean, and minimum temperatures of very hot (IIAw) and hot (IIIAcw) year-long growing seasons. 


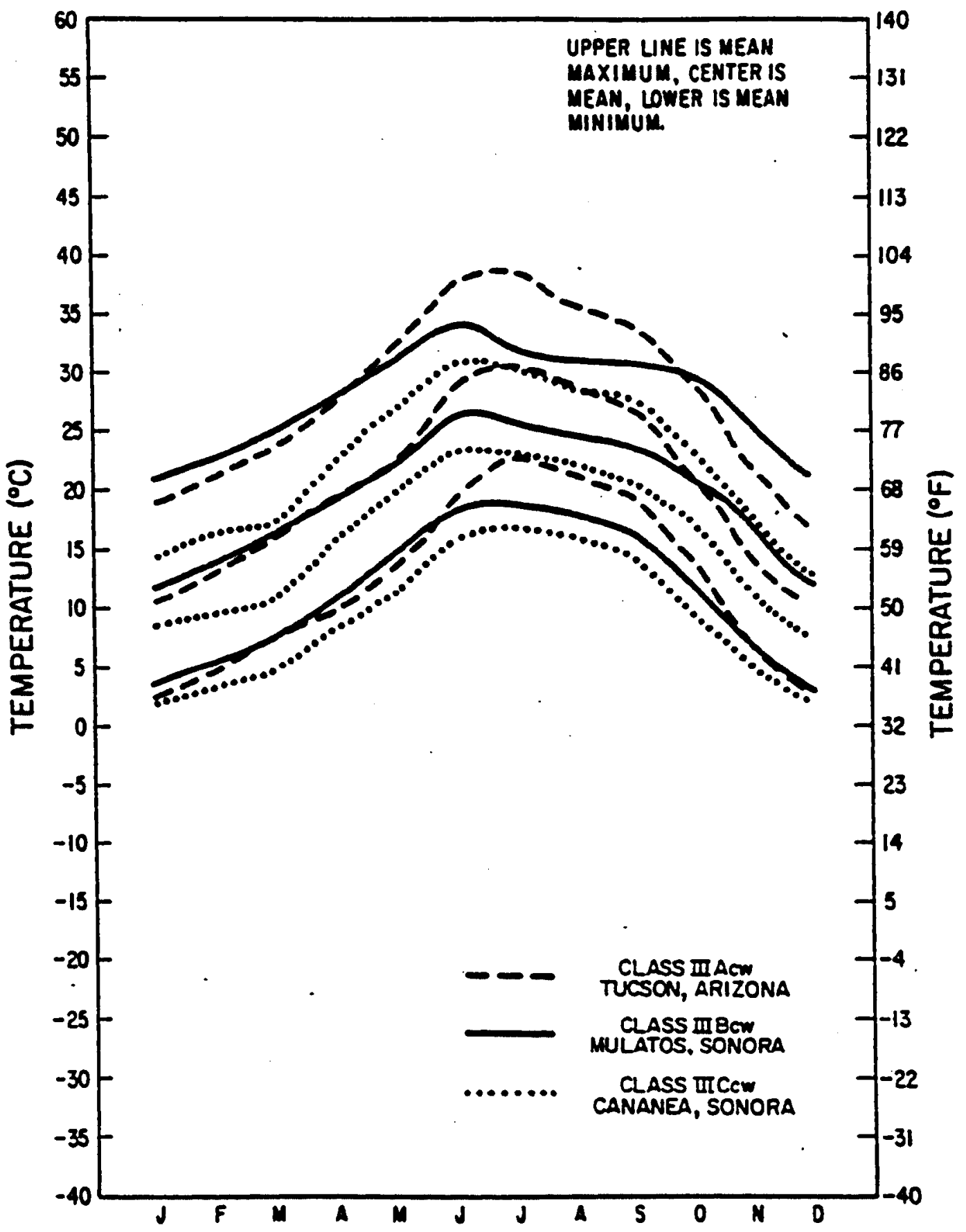

Figure 12. Graph comparing maximum, mean, and minimum temperatures for three year-long hot growing season climate (IIIAcw, IIIBCw, IIICcW). 
Table 6. Climatic data for locations representing hot-moderate temperature growing season climate.

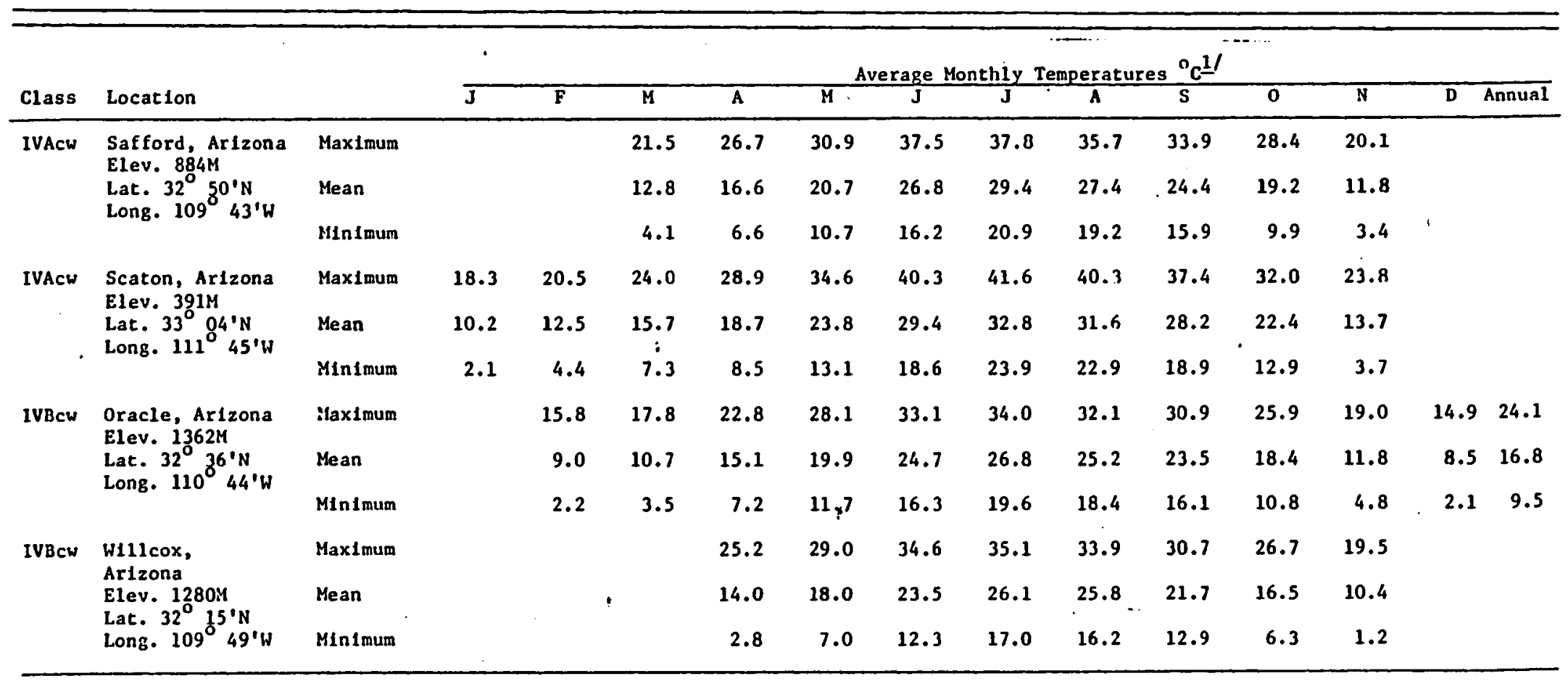

1/U.S. Environmental Data Service, 1980. 


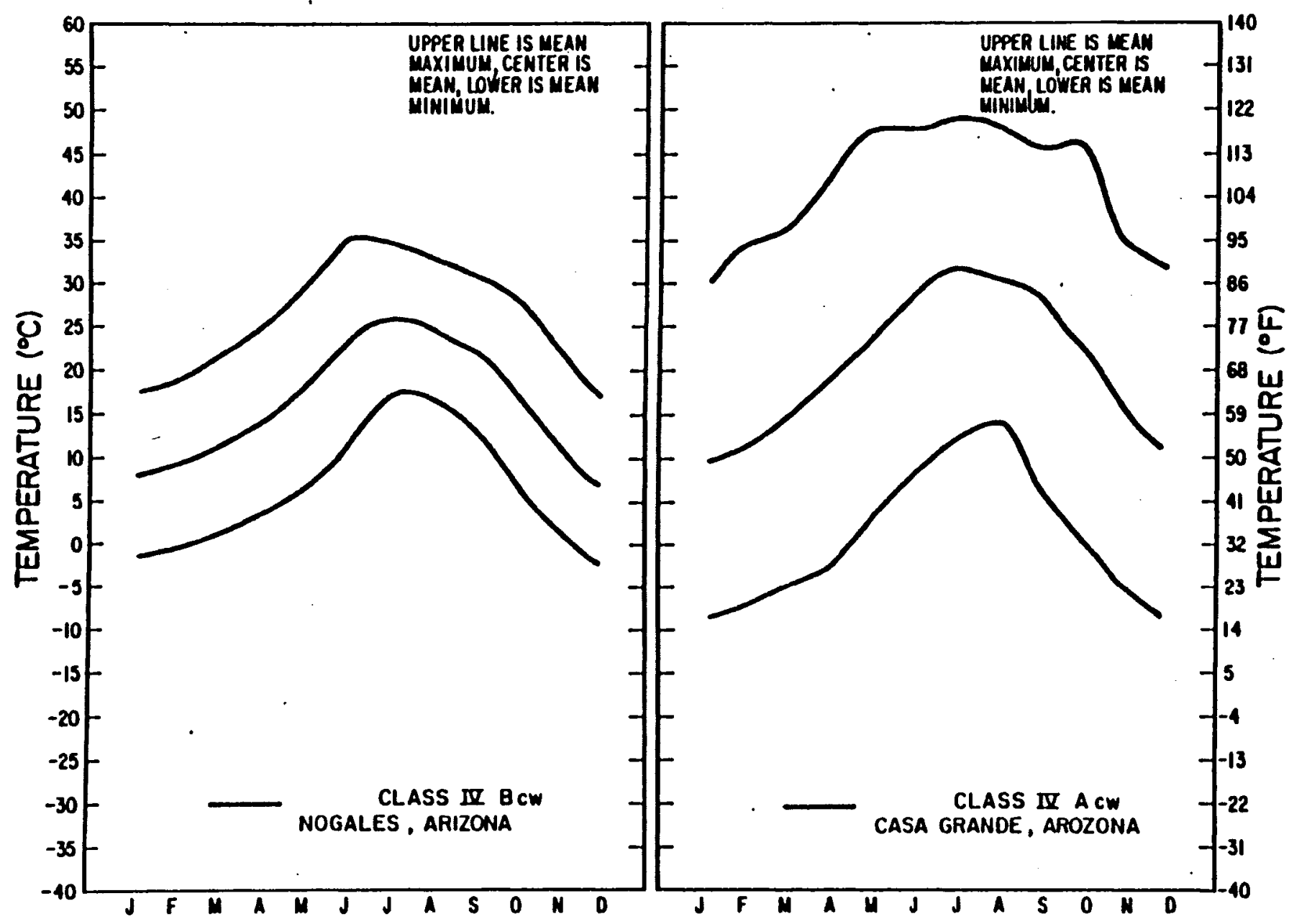

Figure 13. Maximum, mean, and minimum temperatures for locations representing hot-moderate temperature growing season climates. 


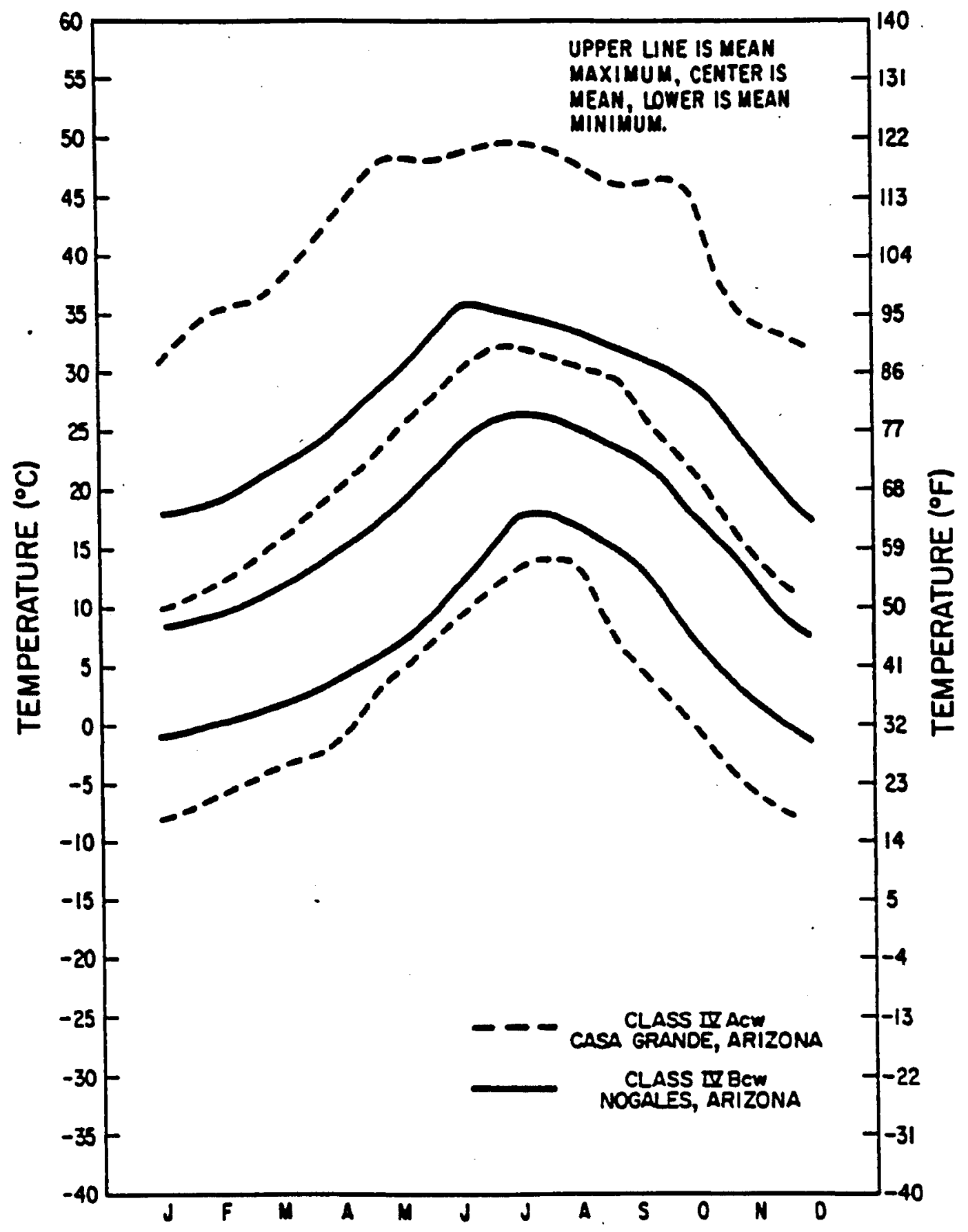

Figure 14. Graph comparing maximum, mean, and minimum temperatures of hot summer (IVACW) and moderate summer (IVBCW) hotmoderate growing season climates. 
Examples of climatic zones with moderate temperature are shown in Table 7 and Figures 15, 16 and 17. The length of the growing season in these five sub-groups is 5 to 8 months. Class VAw, one of the sub-groups, has warm summer temperatures suited to heat tolerant crops such as corn, alfalfa, and watermelons. These crops mature in a relatively short growing season. Class VAcw, with similar features as VAw is warmer with summers suitable for heat tolerant crops.

The climatic class VBw has moderate temperatures suited for hardy crops as alfalfa, sugarbeets, potatoes (Solanum tuberosum L.), irrigated pastures, winter and spring wheats, lettuce, cabbage (Brassica oleracea var. capitata L.), beets, carrots, and spinach. In this area tender crops like corn, grain sorghum, cantaloupe (Cucumis melo L.) and peppers (Capsicum annuum L.) are also adapted. Class VCw has a cold growing season; best suited to hardy crops such as alfalfa, small grains, pastures, potatoes, and cabbage. The sub-group class VCw has cold summers suitable for short-season varieties of sweet corn, tomatoes, peppers, and cantaloupes. Different classes of this group are closely related. For example, a class with the letter $B$ or $C$ may have an average monthly temperature higher than that of A (Figure 18), but the overall average annual temperature of $A$ is higher than that of $B$ or $C$. The moderate-cool temperature growing season climate is illustrated in Table 8 and Figure 19. Class VIcw has a short growing season with a length of $2 \frac{1}{2}$ to 5 months. Summer temperatures in this area are suitable for hardy, cold tolerant crops such as potatoes and irrigated forages. Winter hardy varieties of alfalfa and other cool season 
Table 7. Climatic data for locations representing moderate temperature growing season climate.

\begin{tabular}{|c|c|c|c|c|c|c|c|c|c|c|c|c|c|c|c|}
\hline \multirow[b]{2}{*}{$\mathrm{Cl}$ ass } & \multirow[b]{2}{*}{ Location } & & \multicolumn{13}{|c|}{ Average Monthly Temperatures ${ }^{\circ} \mathrm{C}$} \\
\hline & & & $\overline{\mathbf{J}}$ & $\bar{F}$ & $M$ & $\bar{A}$ & II & $\mathbf{J}$ & $\mathrm{J}$ & $A$ & $s$ & 0 & $\mathbf{N}$ & $\bar{D}$ & $\overline{\text { Annua } 1}$ \\
\hline \multirow[t]{3}{*}{ VAw } & \multirow{3}{*}{$\begin{array}{l}\text { San Simon, Arizona } \\
\text { Elev. } 1082 \mathrm{M} \\
\text { Lat. } 32^{\circ} 22^{\prime} \mathrm{N} \\
\text { Long. } 109^{\circ} 08^{\prime} \mathrm{W}\end{array}$} & Maximum & & & & 26.9 & 31.6 & 36.7 & 36.8 & 34.7 & 33.4 & 27.7 & & & \\
\hline & & Mean & & & & 15.9 & 20.3 & 25.3 & 27.6 & 26.3 & 23.5 & 17.6 & & & \\
\hline & & Minimum & & & & 4.9 & 8.9 & 13.9 & 18.4 & 17.6 & 13.6 & 7.4 & & 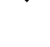 & \\
\hline \multirow[t]{3}{*}{ VAcW } & $\begin{array}{l}\text { Fronteras, } \underline{2} \\
\text { Sonora, Mexico }\end{array}$ & Maximum & & & & 28.7 & 32.5 & 37.4 & 36.1 & 35.4 & 34.8 & 29.6 & & & \\
\hline & $\begin{array}{l}\text { E1ev. } 1127 \mathrm{M} \\
\text { Lat. } 30^{\circ} 56^{\prime} \mathrm{N}\end{array}$ & Mean & & & 1 & 17.2 & 20.6 & 26.0 & 27.0 & 26.5 & 24.4 & 17.9 & & & \\
\hline & Long. $109^{\delta} 30^{\prime} \mathrm{W}$ & Minimum & & & & 5.7 & 8.7 & 14.6 & 18.0 & 17.6 & 14.1 & 6.3 & & & \\
\hline \multirow[t]{3}{*}{ VBW } & $\begin{array}{l}\text { Duncan, Arizona } 3 / \\
\text { Elev. 1115M }\end{array}$ & Maximum & & & & 25.8 & 30.9 & 33.7 & 35.8 & 34.5 & 31.6 & 26.8 & & & \\
\hline & $\begin{array}{l}\text { Lat. } 32^{\circ} 45^{\prime} \mathrm{N} \\
\text { Long. } 109^{\circ} 07 \mathrm{~W}\end{array}$ & Mean & & & & 13.9 & 18.7 & 22.6 & 26.3 & 25.3 & 21.8 & 15.9 & & & \\
\hline & & Minimum & & & & 1.9 & 6.4 & 11.6 & 16.8 & 15.6 & 12.1 & 5.0 & & & \\
\hline \multirow[t]{3}{*}{ vew } & $\begin{array}{l}\text { Granville } \mathrm{e}^{1 /} \\
\text { Arizona }\end{array}$ & Maximum & & & & & 23.5 & 28.8 & 29.4 & 27.7 & 25.9 & 20.2 & & & \\
\hline & $\begin{array}{l}\text { Elev. } 2040 \mathrm{M} \\
\text { Lat. } 33^{\circ} 12^{\prime} \mathrm{N}\end{array}$ & Mean & & & & & 13.8 & 19.4 & 21.4 & 19.8 & 17.5 & 11.9 & & & \\
\hline & Long. $109^{\circ} 23^{\prime} \mathrm{W}$ & Minimum & & & & & 4.1 & 10.1 & 13.4 & 12.0 & 9.1 & 3.6 & & & \\
\hline \multirow[t]{3}{*}{ Vcw } & $\begin{array}{l}\text { Yecora, Yecorn } 2 / \\
\text { Sonora, Mexico }\end{array}$ & Maximum & & & & & 24.3 & 27.7 & 25.0 & 24.7 & 24.4 & 21.8 & & & \\
\hline & $\begin{array}{l}\text { Elev. } 1500 \mathrm{M} \\
\text { Lat. } 28^{\circ} 22^{\prime} \mathrm{N}\end{array}$ & Mean & & & & & 13.7 & 17.7 & 18.8 & 18.1 & 17.0 & 13.0 & & & \\
\hline & Long. $108^{\circ} 57^{\prime} \mathrm{W}$ & Minimum & & & & & 3.1 & 7.8 & 12.6 & 11.6 & 9.7 & 4.3 & & & \\
\hline
\end{tabular}

1/U.S. Environmental Data Service, 1980.

$\frac{1}{3} /$ Servicio Meteorologico Nacional, 1976.

$\overline{3} /$ Green (1962), Green and Kangleser (1967). 


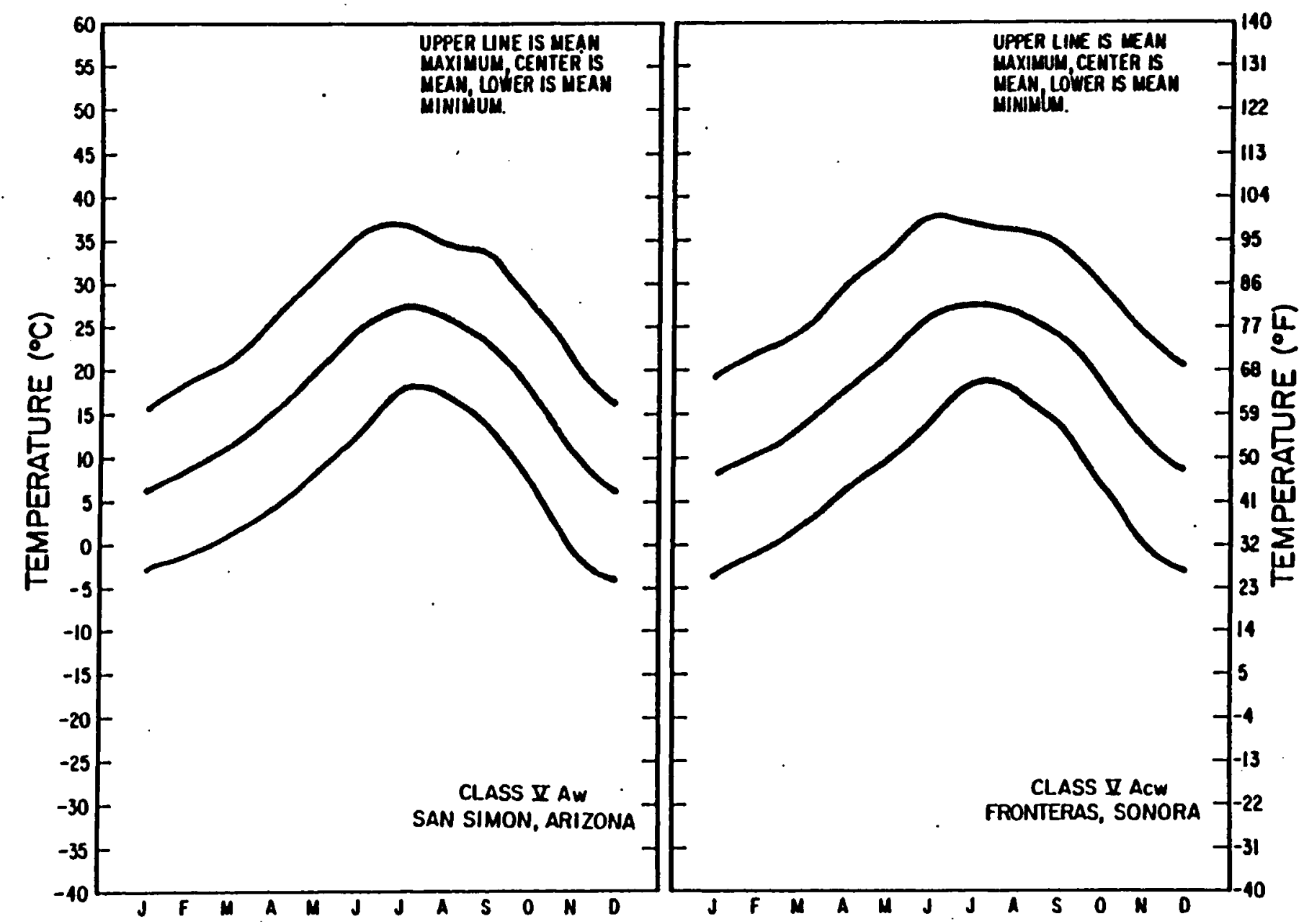

Figure 15. Maximum, mean, and minimum temperatures for locations representing moderate temperature growing season climates with warm summer. 

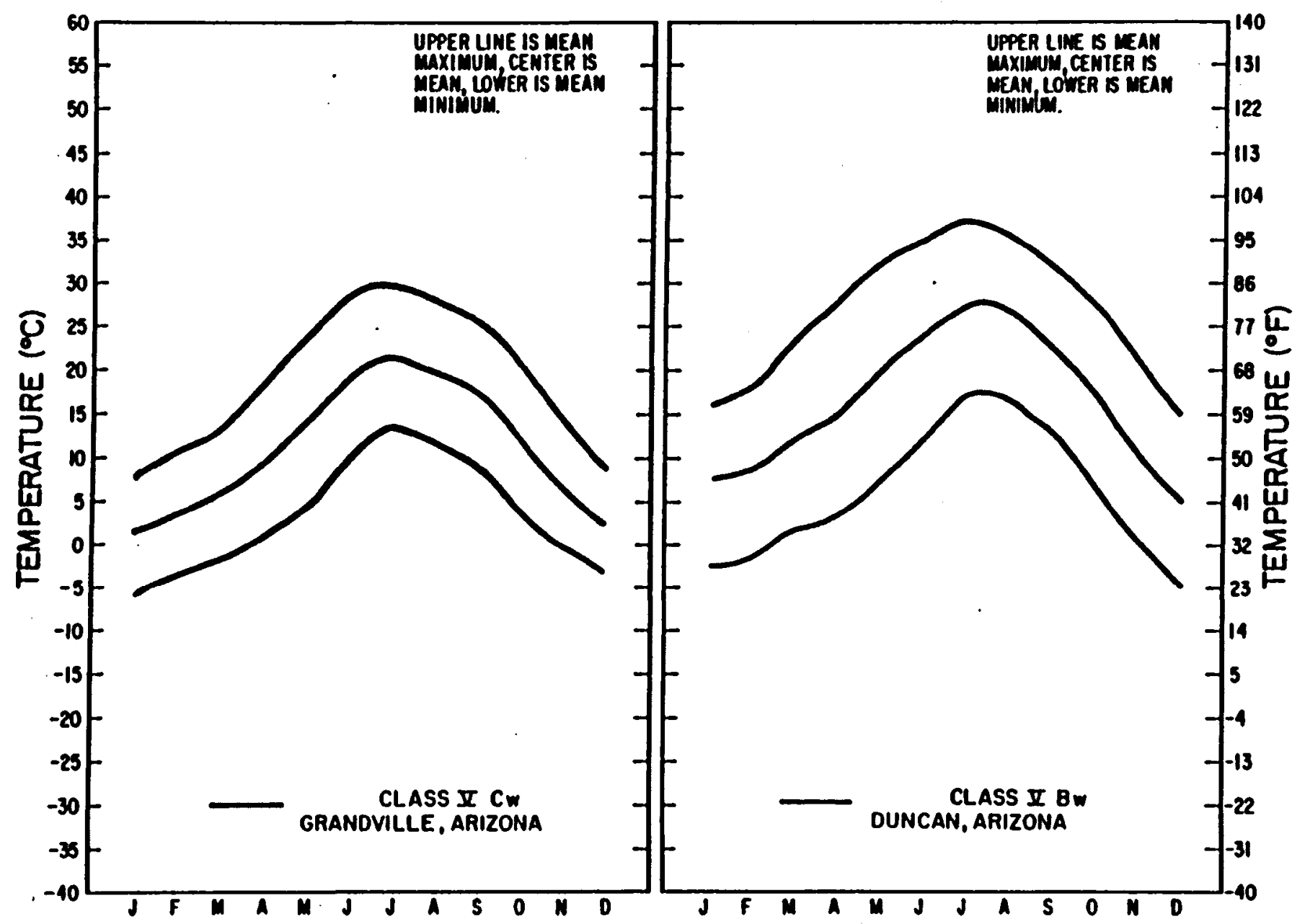

Figure 16. Maximum, mean, and minimum temperatures for locations representing moderate temperature growing season climates with moderate summer. 


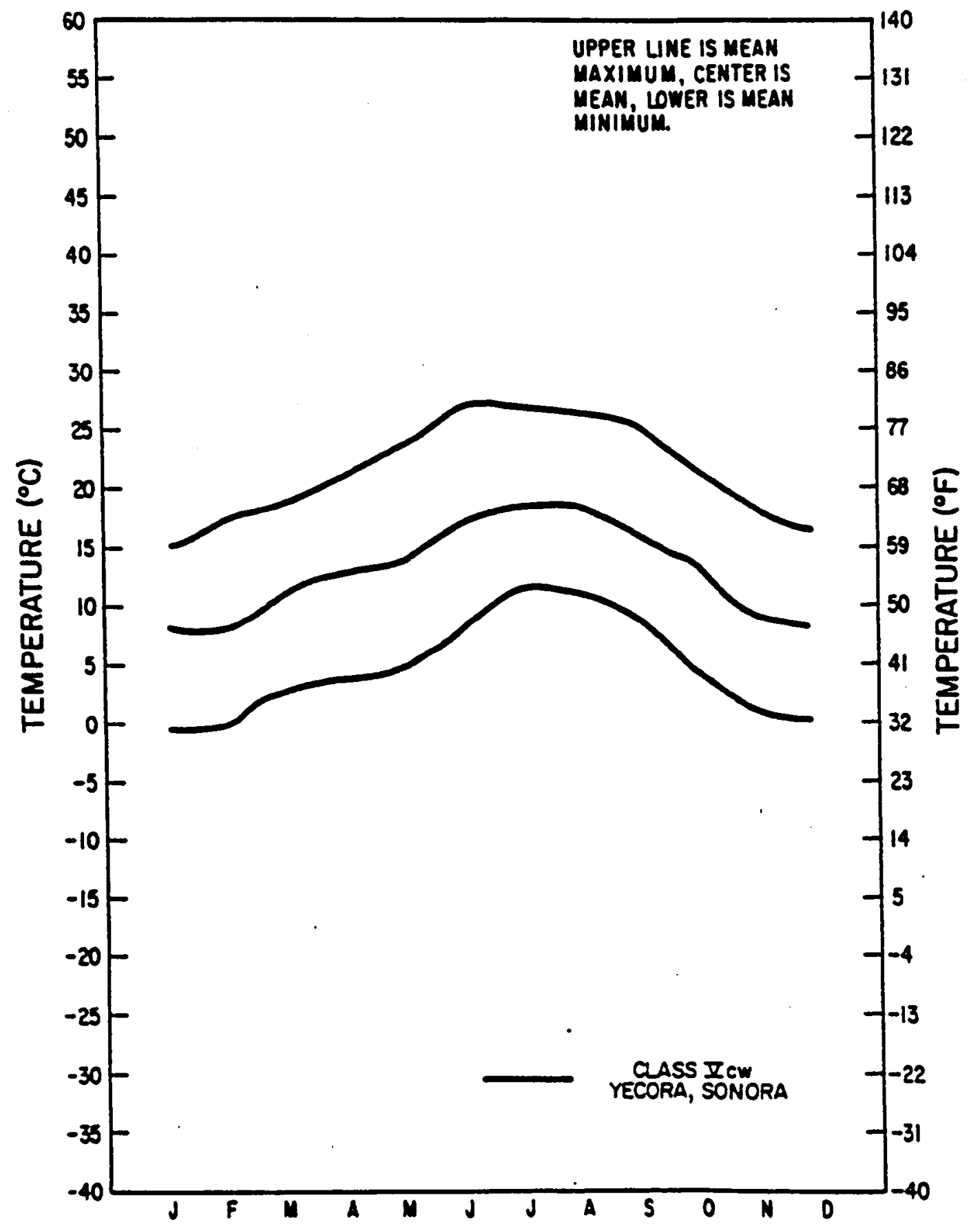

Figure 17. Maximum, mean, and minimum temperatures for a location representing moderate temperature growing season climate with cold summer. 


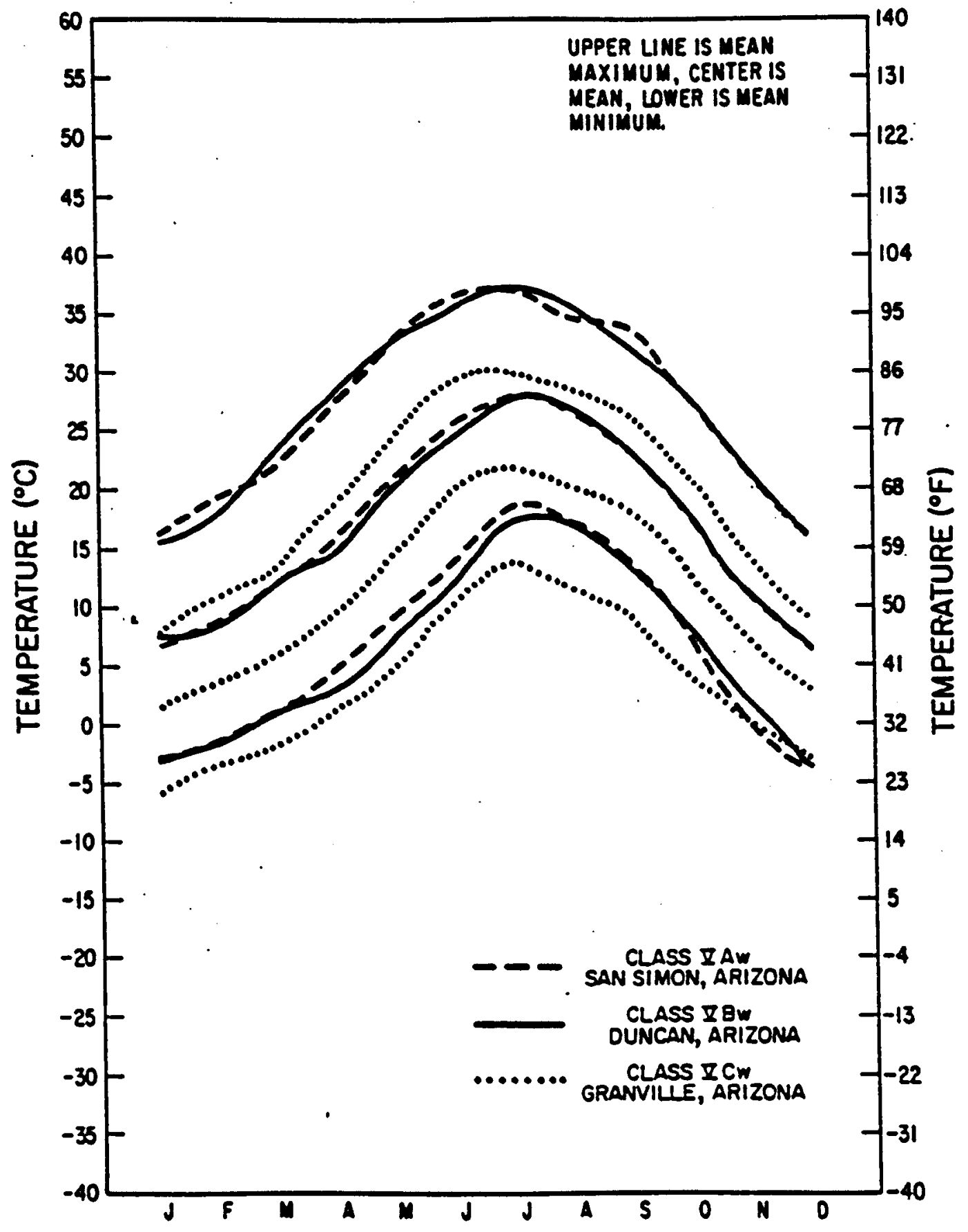

Figure 18. Graph comparing maximum, mean, and minimum temperatures for three moderate-temperature growing season climates (VAw, VBw, VCw). 
Table 8. Climatic data for a location representing moderate-cool temperature growing season climate.

\begin{tabular}{|c|c|c|c|c|c|c|c|c|c|c|c|c|c|c|c|}
\hline \multirow[b]{2}{*}{ Class } & \multirow[b]{2}{*}{ Location } & & \multicolumn{13}{|c|}{ Average Monthly Temperatures ${ }^{\circ} \mathrm{C}-1 /$} \\
\hline & & & $\bar{J}$ & $F$ & $M$ & A & $\mathrm{M}$ & $\mathrm{J}$ & $\mathrm{J}$ & $A$ & $\mathrm{~S}$ & 0 & $\mathrm{~N}$ & D & Annual \\
\hline \multirow[t]{3}{*}{ VIcw } & $\begin{array}{l}\text { Alpine } \\
\text { Arizona }\end{array}$ & Maximum & & & & & & & 25.9 & 24.3 & 22.2 & & & & \\
\hline & $\begin{array}{l}\text { Elev. } 2415 \mathrm{M} \\
\text { Lat. } 33^{\circ} 51^{\prime} \mathrm{N}\end{array}$ & Mean & & & & & & & 16.3 & 15.2 & 12.2 & & & & \\
\hline & Long. $109^{\circ} 08 \mathrm{~W}$ & Minimum & & & & & & & 6.7 & 6.1 & 1.7 & & & & \\
\hline
\end{tabular}

1/U.S. Environmental Data Service, 1980). 


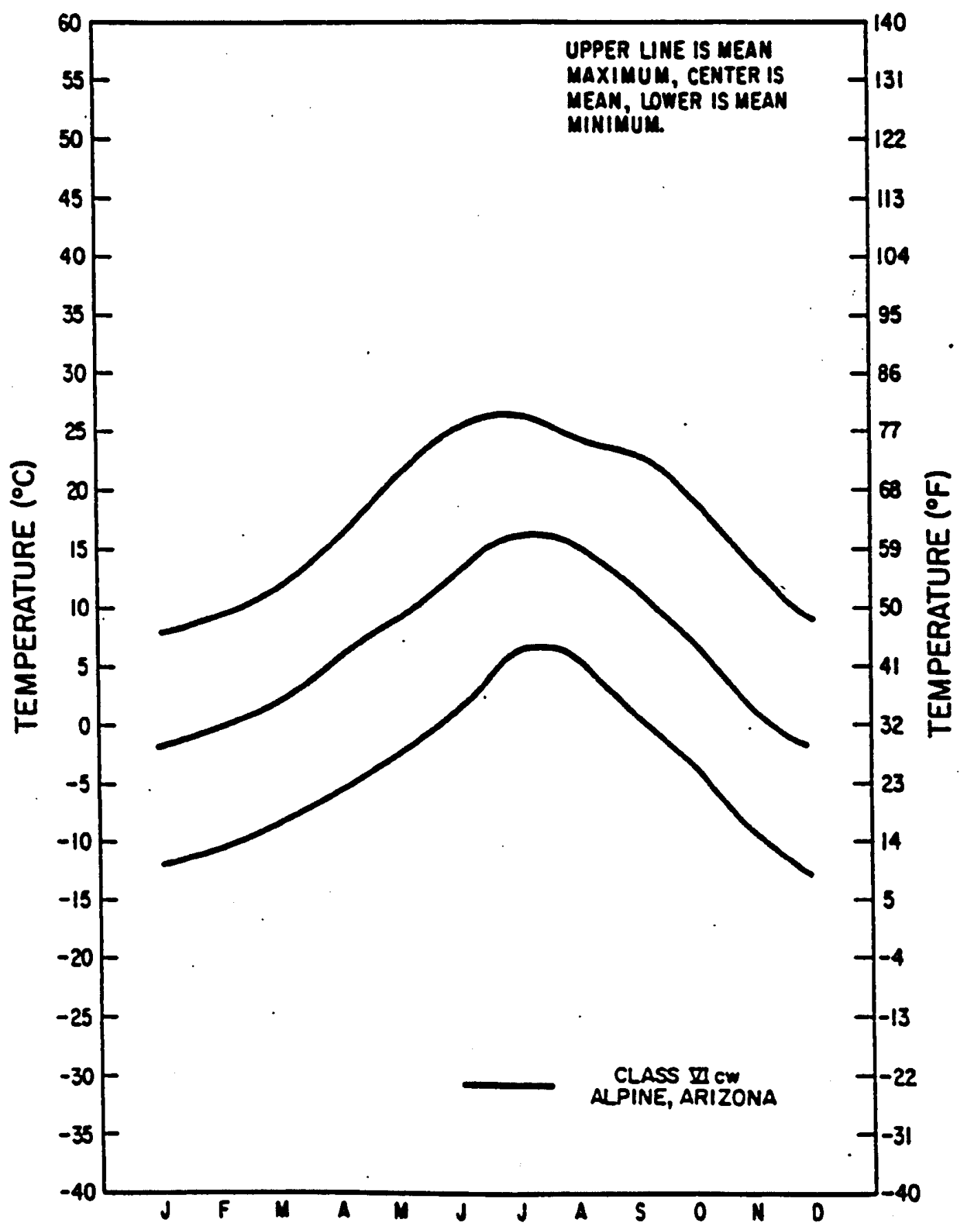

Figure 19. Maximum, mean, and minimum temperatures for a location representing moderate-cool temperature growing season climate. 
legumes and hardy grasses are recommended in this area. The length of the growing season for the climatic class VICw is too short for dry beans and other tender crops but lettuce and cabbage may be grown.

\section{Climate Matching}

One of the objectives of this study was to show the feasibility of matching climates of widely isolated areas throughout the world. Such a procedure, undertaken in a comprehensive way, would pave the way for greatly improved sharing of agronomic research and technology. In this section data from selected stations around the world are used to show their climates are similar to those found in selected locations of Arizona and Sonora. Data in Tabile 9 show how climates at these locations are similar to at least one climatic zone described in this study. With data for average monthly mean maximum, mean, and mean minimum temperatures at any weather station in the world, climate matching as suggested in this study can proceed.

The procedure for this should include the following steps:

a) Obtain climatic data from weather stations representative of areas of interest and estimate which of the zones described in Tables 1 and 2 they are most nearly like. b) Plot maximum, mean, and minimum data for each weather station, as has been done in the several figures in this study. Then, using transparenctes, or in other appropriate ways, compare data so as to determine those having the best fit. Land areas which have similar maximum, mean, and minimum temperatures will 1ikely be suited to similar crops, crop cultivars, and cropping.practices. 
Table 9. Matching of climatic data of selected stations around the world to some of the classes obtained in this classification. 1 /

\begin{tabular}{|c|c|c|c|c|c|c|c|c|c|c|c|c|c|c|c|c|c|c|c|c|}
\hline \multirow[b]{2}{*}{ Class } & \multirow[b]{2}{*}{ Station } & \multirow[b]{2}{*}{ Country } & \multirow{2}{*}{$\begin{array}{l}\text { Elevation } \\
\text { in Ieters }\end{array}$} & \multirow{2}{*}{ Lat1tude } & \multirow[b]{2}{*}{ Longl tude } & \multirow[b]{2}{*}{ Years } & & \multirow[b]{2}{*}{$\overline{\mathrm{J}}$} & \multirow[b]{2}{*}{$F$} & \multirow[b]{2}{*}{ 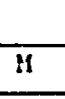 } & \multicolumn{8}{|c|}{ Average Monthly Temperature ${ }^{\circ} \mathrm{C}$} & \multirow[b]{2}{*}{ D } & \multirow[b]{2}{*}{ Annual } \\
\hline & & & & & & & & & & & A & $M$ & $\mathbf{J}$ & $\mathbf{J}$ & A & $\mathbf{S}$ & 0 & $\mathbf{N}$ & & \\
\hline \multirow{3}{*}{ IAw } & \multirow{3}{*}{ Khartoum } & \multirow{3}{*}{ Sudan } & \multirow{3}{*}{380} & \multirow{3}{*}{$15^{\circ} 36^{\prime} \mathrm{N}$} & \multirow{3}{*}{$32^{\circ} 33^{\prime} \mathrm{E}$} & \multirow{3}{*}{35} & Ilaximum & 32 & 34 & 38 & 41 & 42 & 41 & 38 & 37 & 39 & 40 & 36 & 33 & 37 \\
\hline & & & & & & & Ilean & 24 & 25 & 28 & 31 & 33 & 34 & 32 & 31 & 32 & 32 & 28 & 25 & 29 \\
\hline & & & & & & & Minfmum & 15 & 16 & 19 & 22 & 25 & 26 & 25 & 24 & 25 & 24 & 20 & 17 & 22 \\
\hline \multirow{3}{*}{ IIAw } & \multirow{3}{*}{ Kuwait } & \multirow{3}{*}{ Kuwa1t } & \multirow{3}{*}{54.8} & \multirow{3}{*}{$29^{\circ} 14^{\prime} \mathrm{N}$} & \multirow{3}{*}{$47^{\circ} 59^{\prime} \mathrm{E}$} & \multirow{3}{*}{ i 11} & Maximum & 16 & 19 & 22 & 28 & 34 & 37 & 39 & 40 & 38 & 33 & 25 & 18 & 29 \\
\hline & & & & & & & Mean & 13 & 15 & 19 & 24. & 30 & 33 & 35 & 35 & 33 & 28 & 21 & 15 & 25 \\
\hline & & & & & & & Minimum & 9 & 11 & 15 & 20 & 25 & 28 & 30 & 30 & 27 & 23 & 17 & 12 & 21 \\
\hline \multirow{3}{*}{ IIAcW } & \multirow{3}{*}{ Marrakech } & & \multirow{3}{*}{465.5} & \multirow{3}{*}{$31^{\circ} 37^{\prime} \mathrm{N}$} & & & Maximum & 18 & 20 & 23 & 26 & 29 & 33 & 38 & 38 & 33 & 28 & 23 & 19 & 27 \\
\hline & & Morocco & & & $8^{\circ} 02^{\prime} \mathrm{E}$ & 34 & Mean & 12 & 13 & 16 & 19 & 22 & 25 & 29 & 29 & 25 & 21 & 16 & 13 & 20 \\
\hline & & . & & & & & Min1mum & 5 & 6 & 9 & 11 & 14 & 17 & 19 & 20 & 17 & 14 & 9 & 6 & 12 \\
\hline IIBCW , & Palermo & Italy & 31.1 & $38^{\circ} 06^{\prime} \mathrm{N}$ & $13^{\circ} 20^{\prime} \mathrm{E}$ & 20 & $\begin{array}{l}\text { Maximum } \\
\text { llean }\end{array}$ & 14 & 16 & 17 & 19 & 28 & 28 & 30 & 31 & 28 & 24 & 19 & 16 & $\begin{array}{l}23 \\
19\end{array}$ \\
\hline & & & & & & & Minimum & 8 & 8 & 9 & 12 & 15 & 19 & 22 & 22 & 21 & 17 & 13 & 10 & 14 \\
\hline & & & & & & & Maxinum & 19 & 21 & 24 & 25 & 26 & 24 & 23 & 23 & 23 & 21 & 20 & 19 & 22 \\
\hline II $\mathbf{c w}$ & $\begin{array}{l}\text { :lexico } \\
\text { C1ty }\end{array}$ & Mexico & 2301.7 & $19^{\circ} 26^{\prime} \mathrm{N}$ & $99^{\circ} 08^{\prime} \mathrm{W}$ & 15 & Mean & 13 & 14 & 16 & 18 & 14 & 19 & 18 & 18 & 18 & 16 & 14 & 13 & 14 \\
\hline & & & & & & & MinInum & 6 & 6 & 8 & 11 & 12 & 13 & 12 & 12 & 12 & 10 & 8 & 6 & 9 \\
\hline
\end{tabular}


Table 9--Continued.

\begin{tabular}{|c|c|c|c|c|c|c|c|c|c|c|c|c|c|c|c|c|c|c|c|c|}
\hline \multirow[b]{2}{*}{ Class } & \multirow[b]{2}{*}{ Station } & \multirow[b]{2}{*}{ Country } & \multirow{2}{*}{$\begin{array}{l}\text { Elevation } \\
\text { In Heters }\end{array}$} & \multirow[b]{2}{*}{ Latitude } & \multirow[b]{2}{*}{ Longlt tude } & \multirow[b]{2}{*}{ Years } & & \multicolumn{13}{|c|}{ Average Monthly Temperature ${ }^{\circ} c^{1 /}$} \\
\hline & & & & & & & & $\mathbf{J}$ & $\mathbf{F}$ & $M$ & $A^{\circ}$ & $M$ & $\mathrm{~J}$ & $\mathrm{~J}$ & $\mathrm{~A}$ & $\mathbf{S}$ & 0 & $N$ & $\bar{D}$ & Annual \\
\hline \multirow{3}{*}{ IIIACW } & \multirow{3}{*}{ Baghdad } & \multirow{3}{*}{ Iraq } & \multirow{3}{*}{37} & \multirow{3}{*}{$33^{\circ} 21^{\prime} \mathrm{N}$} & \multirow{3}{*}{$44^{\circ} 24^{\prime} \mathrm{E}$} & \multirow{3}{*}{30} & Maximum & 16 & 18 & 22 & 29 & 36 & 41 & 43 & 43 & 40 & 33 & 25 & 18 & 31 \\
\hline & & & & & & & Mean & 10 & 12 & 15 & 22 & 28 & 32 & 34 & 34 & 31 & 25 & 19 & 12 & 23 \\
\hline & & & & & & & Minimum & 4 & 6 & 9 & 14 & 19 & 23 & 24 & 24 & 21 & 16 & 11 & 6 & 1.5 \\
\hline \multirow{3}{*}{ IIICW } & \multirow{3}{*}{ Katmandu } & \multirow{3}{*}{ Nepal } & \multirow{3}{*}{1286.9} & \multirow{3}{*}{$27^{\circ} 42^{\prime} \mathrm{N}$} & \multirow{3}{*}{$85^{\circ} 20^{\prime} \mathrm{E}$} & \multirow{3}{*}{10} & Maximum & 18 & 19 & 25 & 28 & 30 & 29 & 29 & 28 & 28 & 27 & 23 & 19 & 26 \\
\hline & & & & & & & Mean & 10 & 12 & 16 & 20 & 23 & 24 & 25 & 24 & 24 & 20 & 15 & 11 & 19 \\
\hline & & & & & & & Minimum & 2 & 4 & 7 & 12 & 16 & 19 & 20 & 20 & 19 & 13 & 7 & 3 & 12 \\
\hline \multirow{3}{*}{ IVACW } & \multirow{3}{*}{ Tehran } & \multirow{3}{*}{ Iran } & \multirow{3}{*}{1219} & \multirow{3}{*}{$35^{\circ} 41^{\prime} \mathrm{N}$} & \multirow{3}{*}{$51^{\circ} 19^{\prime} E$} & \multirow{3}{*}{30} & Maximum & 7 & 10 & 15 & 22 & 28 & 34 & 37 & 36 & 32 & 24 & 17 & 11 & 23 \\
\hline & & & & & & & Mean & 2 & 5 & 9 & 16 & 21 & 26 & 30 & 29 & 25 & 18 & 12 & 6 & 17 \\
\hline & & & & & & & Minimum & -3 & 00 & 4 & 9 & 14 & 19 & 22 & 22 & 18 & 12 & 6 & 1 & 11 \\
\hline \multirow{3}{*}{ Vew } & & & & & & & Maximum & -5 & $-2 !$ & 4 & 14 & 22 & 27 & 29 & 28 & 21 & 13 & 4 & -1 & 13 \\
\hline & Astrakhan & U.S.S.R. & 14 & $46^{\circ} 15^{\prime} \mathrm{N}$ & $48^{\circ} 02^{\prime} \mathrm{E}$ & 30 & Mean & -8 & -5 & 00 & 9 & 18 & 23 & 25 & 23 & 16 & 9 & 2 & -3 & 9 \\
\hline & & & & & & & MInimum & -10 & -8 & -4 & 4 & 13 & 19 & 21 & 18 & 12 & 4 & -1 & -6 & 5 \\
\hline & & & & & & & Maximum & 2 & 5 & 9 & 15 & 20 & 26 & 28 & 27 & 24 & 18 & 9 & 3 & 16 \\
\hline VIcw & $\begin{array}{l}\text { Almaso } \\
\text { Colorado }\end{array}$ & U.S.A. & 2296 & $37^{\circ} 27^{\prime} \mathrm{N}$ & $105^{\circ} 52^{\prime} \mathrm{W}$ & 30 & Mean & -8 & -5 & 00 & 6 & 11 & 16 & 18 & 17 & 13 & 7 & -2 & -7 & 6 \\
\hline & & & & & & & Minimum & -18 & -14 & -9 & -4 & 1 & 5 & 8 & 8 & 2 & -4 & -12 & -18 & -4 \\
\hline
\end{tabular}

I/WMO (1965), Wernstedt (1972), Walter, Harnickell and Muller (1975), and WMO (1980). 
The method suggested in (b) is suitable for use in the Northern hemisphere as the temperature trend in the southern hemisphere is different. When comparing temperature of climates in the Northern hemisphere with those in the south, it is necessary to disregard the month in which a given mean occurs. If this is done, temperatures of climates occurring anywhere in the world may be compared. 
SUMMARY AND CONCLUSION

Two main features for classifying the growing season using average monthly temperatures have been proposed in this study. These features are 1) the length of the growing season and 2) the temperature characteristics of the season. On the basis of assumed features, 20 different growing season classes for Arizona, United States and Sonora, Mexico have been described. Finally, in a preliminary way, methods for matching the growing seasons of the areas represented with those occurring at other locations in the world, are described.

For ease in understanding the principal temperature criteria used for classification, the 20 different growing seasons included in this study were:

1. Year-long growing season

Double and other multiple cropping is often practiced in this area having a year-long growing season. This study area having 11 of the 20 groups included in this study, have climates that are year-long and frost free.

a. Extremely hot

Two of the climate classes are extremely hot. Minimum monthly mean temperatures never fall below $10^{\circ} \mathrm{C}$. These are IAw and Iw with IAw having higher sumer temperatures than Iw.

b. Very hot

The mean minimum monthly temperature for this area never falls below $5^{\circ} \mathrm{C}$ and it includes four classes IIAw, IIACw, IIBCw, and 
IIcw. The classes IIAw and IIAcw are very similar, but IIAcw has a cooler spring and fall. The climate of IIBCw is cooler than all sub-groups in this category.

c. Hot

The mean minimum monthly temperature of these climate groups is not less than $1.7^{\circ} \mathrm{C}$, and includes five sub-groups IIIAcw, IIIAw, IIIBCw, IIICw, and IIICcw. Classes IIIACw and IIIAw are closely related with IIIAcw having a cooler spring and fall. Both classes IIIAcw and IIIAw are warmer than the other classes. These climatic areas differ primarily in the temperatures that occur during the summer, with IIICcw being the coolest.

2. Hot-moderate growing season

The length of the growing season for the climatic areas having this classification ranges from 8 to 12 months and sumer temperatures are hot (IVACw) or moderate (IVBCw). These climate classes account for much of the irrigated land in Arizona, United States.

3. Moderate-temperature growing season

There are five climate areas having a moderate temperature growing season, with the length varying from 5 to 8 months. The classes with this growing season are VAw, VAcw, VBw, VCw, and VCw, with VAcw being warmest and Vcw coolest.

4. Moderate-cool growing season

The length of growing season for this class (VIcw) ranges from $2 \frac{1}{2}$ to 5 months, too cool, and too short for many crops. 
5. Cool-growing season

The land areas having a growing season of less than $2 \frac{1}{2}$ months (VIIw) are all located in Arizona, United States, and are at the highest elevations.

In this study a method of matching climates is also proposed and described. Careful matching of climates will facilitate sharing of research and experiences relative to the production of agronomic and horticultural crops. Ultimately, such sharing will help farmers and others to improve their efficiency of production. 
APPENDIX A

AVERAGE MONTHLY TEMPERATURE

OF SELECTED LOCATIONS IN

ARIZONA AND SONORA 
Table A.1. Average monthly temperatures of selected stations in Arizona, United States. $\underline{\text { / }}$

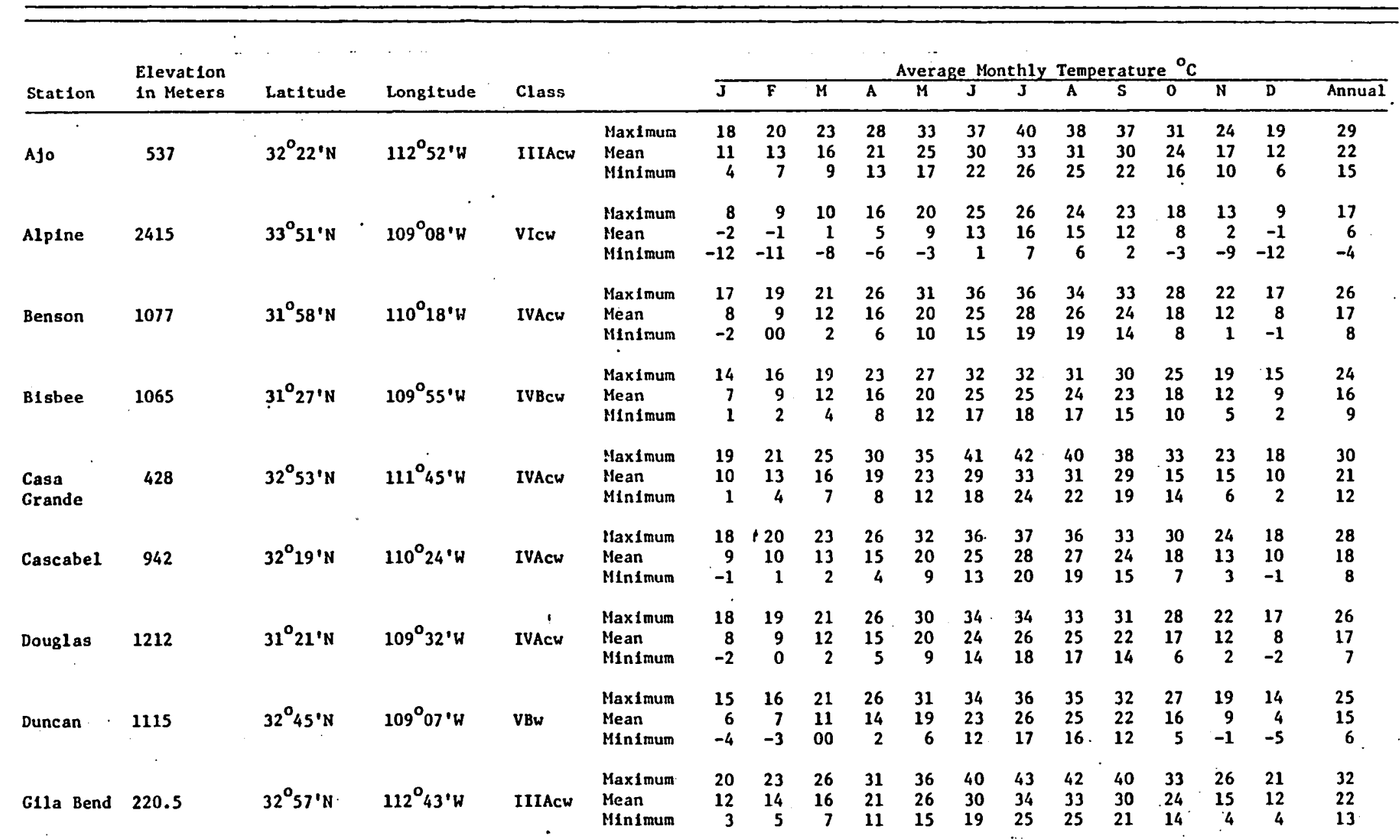


Table A.1.--Continued.

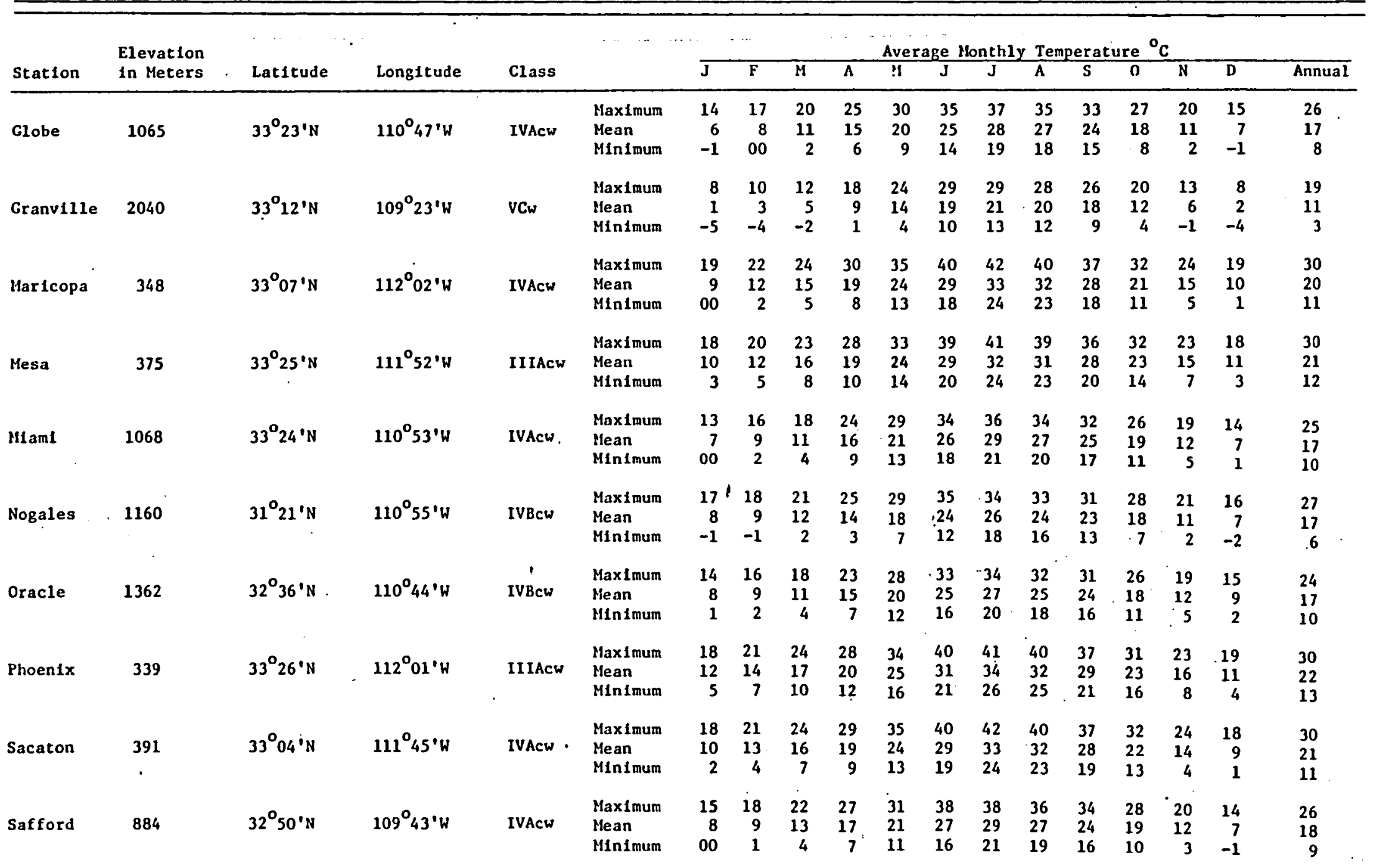


Table A.1.-- Continued.

\begin{tabular}{|c|c|c|c|c|c|c|c|c|c|c|c|c|c|c|c|c|c|c|}
\hline \multirow[b]{2}{*}{ Station } & \multirow{2}{*}{$\begin{array}{l}\text { Elevation } \\
\text { in Meters }\end{array}$} & \multirow[b]{2}{*}{ Lat1tude } & \multirow[b]{2}{*}{ Longltude } & \multirow[b]{2}{*}{ Class } & & \multicolumn{13}{|c|}{ Average Monthly Temperature ${ }^{\circ} \mathrm{C}$} \\
\hline & & & & & & $\mathbf{J}$ & $\mathbf{F}$ & $M$ & A & $M$ & $\mathrm{~J}$ & $\mathrm{~J}$ & A & $\mathbf{S}$ & 0 & $N$ & D & Annual \\
\hline Salome & 570 & $33^{\circ} 47^{\prime} \mathrm{N}$ & $113^{\circ} 37^{\prime} \mathrm{W}$ & IVAcw & $\begin{array}{l}\text { Maximum } \\
\text { Mean } \\
\text { Minimum }\end{array}$ & $\begin{array}{r}17 \\
9 \\
00\end{array}$ & $\begin{array}{r}20 \\
11 \\
2\end{array}$ & $\begin{array}{r}23 \\
13 \\
3\end{array}$ & $\begin{array}{r}27 \\
14 \\
7\end{array}$ & $\begin{array}{l}33 \\
22 \\
12\end{array}$ & $\begin{array}{l}38 \\
27 \\
16\end{array}$ & $\begin{array}{l}40 \\
31 \\
22\end{array}$ & $\begin{array}{l}39 \\
30 \\
21\end{array}$ & $\begin{array}{l}37 \\
27 \\
17\end{array}$ & $\begin{array}{l}31 \\
21 \\
10\end{array}$ & $\begin{array}{r}23 \\
14 \\
5\end{array}$ & $\begin{array}{r}18 \\
9 \\
00\end{array}$ & $\begin{array}{l}29 \\
19 \\
10\end{array}$ \\
\hline San Carlos & 793 & $33^{\circ} 21^{\prime} \mathrm{N}$ & $110^{\circ} 27^{\prime} \mathrm{W}$ & IVACW & $\begin{array}{l}\text { Max1mum } \\
\text { Mean } \\
\text { Minimum }\end{array}$ & $\begin{array}{r}17 \\
7 \\
-3\end{array}$ & $\begin{array}{r}20 \\
9 \\
-1\end{array}$ & $\begin{array}{r}22 \\
12 \\
2\end{array}$ & $\begin{array}{r}28 \\
16 \\
4\end{array}$ & $\begin{array}{r}33 \\
20 \\
8\end{array}$ & $\begin{array}{l}37 \\
25 \\
13\end{array}$ & $\begin{array}{l}38 \\
29 \\
20\end{array}$ & $\begin{array}{l}37 \\
28 \\
19\end{array}$ & $\begin{array}{l}35 \\
25 \\
15\end{array}$ & $\begin{array}{r}29 \\
18 \\
7\end{array}$ & $\begin{array}{l}22 \\
11 \\
00\end{array}$ & $\begin{array}{r}17 \\
7 \\
-3\end{array}$ & $\begin{array}{r}28 \\
17 \\
7\end{array}$ \\
\hline San Simon & 1082 & $32^{\circ} 22^{\prime} \mathrm{N}$ & $109^{\circ} 08^{\prime} \mathrm{W}$ & VAw & $\begin{array}{l}\text { Maximum } \\
\text { Mean } \\
\text { Minimum }\end{array}$ & $\begin{array}{r}15 \\
6 \\
-3\end{array}$ & $\begin{array}{r}19 \\
9 \\
-2\end{array}$ & $\begin{array}{r}21 \\
11 \\
1\end{array}$ & $\begin{array}{r}27 \\
16 \\
5\end{array}$ & $\begin{array}{r}32 \\
20 \\
9\end{array}$ & $\begin{array}{l}37 \\
25 \\
14\end{array}$ & $\begin{array}{l}37 \\
28 \\
18\end{array}$ & $\begin{array}{l}35 \\
26 \\
18\end{array}$ & $\begin{array}{l}33 \\
24 \\
14\end{array}$ & $\begin{array}{r}28 \\
18 \\
7\end{array}$ & $\begin{array}{l}21 \\
10 \\
00\end{array}$ & $\begin{array}{r}16 \\
7 \\
-3\end{array}$ & $\begin{array}{r}27 \\
17 \\
7\end{array}$ \\
\hline Scottsdale & 368 & $33^{\circ} 30^{\prime} \mathrm{N}$ & $111^{\circ} 55^{\prime} \mathrm{W}$ & IIIACW & $\begin{array}{l}\text { Maximum } \\
\text { Mean } \\
\text { Minimum }\end{array}$ & $\begin{array}{r}19 \\
11 \\
3\end{array}$ & $\begin{array}{r}21 \\
13 \\
4\end{array}$ & $\begin{array}{r}25 \\
15 \\
6\end{array}$ & $\begin{array}{l}29 \\
20 \\
10\end{array}$ & $\begin{array}{l}34 \\
24 \\
14\end{array}$ & $\begin{array}{l}39 \\
28 \\
18\end{array}$ & $\begin{array}{l}41 \\
32 \\
23\end{array}$ & $\begin{array}{l}39 \\
31 \\
23\end{array}$ & $\begin{array}{l}38 \\
28 \\
19\end{array}$ & $\begin{array}{l}32 \\
22 \\
13\end{array}$ & $\begin{array}{r}25 \\
16 \\
6\end{array}$ & $\begin{array}{r}20 \\
12 \\
3\end{array}$ & $\begin{array}{l}30 \\
21 \\
12\end{array}$ \\
\hline Tempe & 350 & $33^{\circ} 26^{\prime} \mathrm{N}$ & $111^{\circ} 56^{\prime} \mathrm{W}$ & IIIAcW & $\begin{array}{l}\text { Maximum } \\
\text { Mean } \\
\text { Minimum }\end{array}$ & $\begin{array}{r}18 \\
11 \\
3\end{array}$ & $\begin{array}{r}21 \\
13 \\
5\end{array}$ & $\begin{array}{r}24 \\
16 \\
8\end{array}$ & $\begin{array}{r}29 \\
19 \\
9\end{array}$ & $\begin{array}{l}34 \\
23 \\
13\end{array}$ & $\begin{array}{l}40 \\
29 \\
18\end{array}$ & $\begin{array}{l}41 \\
32 \\
24\end{array}$ & $\begin{array}{r}39 \\
31 \\
\cdot 22\end{array}$ & $\begin{array}{l}37 \\
28 \\
19\end{array}$ & $\begin{array}{l}33 \\
23 \\
13\end{array}$ & $\begin{array}{r}24 \\
15 \\
7\end{array}$ & $\begin{array}{r}19 \\
14 \\
2\end{array}$ & $\begin{array}{l}29 \\
20 \\
11\end{array}$ \\
\hline Tucson & 787 & $32^{\circ} 07$ N & $110^{\circ} 56^{\prime} \mathrm{W}$ & IIIACW & $\begin{array}{l}\text { Maximum } \\
\text { Mean } \\
\text { Min1mum }\end{array}$ & $\begin{array}{r}18 \\
10 \\
2 \\
\vdots\end{array}$ & $\begin{array}{r}21 \\
13 \\
5\end{array}$ & $\begin{array}{r}23 \\
15 \\
8\end{array}$ & $\begin{array}{l}27 \\
18 \\
10\end{array}$ & $\begin{array}{l}32 \\
33 \\
13\end{array}$ & $\begin{array}{l}38 \\
29 \\
20\end{array}$ & $\begin{array}{l}38 \\
31 \\
23\end{array}$ & $\begin{array}{l}36 \\
29 \\
22\end{array}$ & $\begin{array}{l}34 \\
27 \\
20\end{array}$ & $\begin{array}{l}29 \\
22 \\
14 .\end{array}$ & $\begin{array}{r}22 \\
14 \\
7\end{array}$ & $\begin{array}{r}17 \\
10 \\
3\end{array}$ & $\begin{array}{l}28 \\
20 \\
11\end{array}$ \\
\hline Welton & 78 & $32^{\circ} 40^{\prime} \mathrm{N}$ & $114^{\circ} 08^{\prime} \mathrm{W}$. & IVAcw & $\begin{array}{l}\text { Maximum } \\
\text { Mean } \\
\text { MIn1mum }\end{array}$ & $\begin{array}{r}20 \\
11 \\
2\end{array}$ & $\begin{array}{r}23 \\
13 \\
3\end{array}$ & $\begin{array}{r}26 \\
16 \\
6\end{array}$ & $\begin{array}{l}30 \\
20 \\
10\end{array}$ & $\begin{array}{l}34 \\
24 \\
14\end{array}$ & $\begin{array}{l}38 \\
28 \\
18\end{array}$ & $\begin{array}{l}41 \\
33 \\
24\end{array}$ & $\begin{array}{l}40 \\
32 \\
24\end{array}$ & $\begin{array}{l}38 \\
29 \\
20\end{array}$ & $\begin{array}{l}33 \\
23 \\
13\end{array}$ & $\begin{array}{r}25 \\
15 \\
5\end{array}$ & $\begin{array}{r}20 \\
11 \\
1\end{array}$ & $\begin{array}{l}31 \\
21 \\
12\end{array}$ \\
\hline Wickenburg & 628.5 & $33^{\circ} 58^{\prime} \mathrm{N}$ & $112^{\circ} 44^{\prime} \mathrm{W}$ & IVACW & $\begin{array}{l}\text { Maximum } \\
\text { Mean } \\
\text { Minimum }\end{array}$ & $\begin{array}{r}17 \\
8 \\
-1\end{array}$ & $\begin{array}{r}20 \\
10 \\
1\end{array}$ & $\begin{array}{r}22 \\
12 \\
3\end{array}$ & $\begin{array}{r}27 \\
17 \\
6\end{array}$ & $\begin{array}{l}32 \\
21 \\
10\end{array}$ & $\begin{array}{l}37 \\
26 \\
14\end{array}$ & $\begin{array}{l}40 \\
30 \\
21\end{array}$ & $\begin{array}{l}38 \\
29 \\
20\end{array}$ & $\begin{array}{l}36 \\
26 \\
15\end{array}$ & $\begin{array}{r}30 \\
19 \\
9\end{array}$ & $\begin{array}{r}23 \\
13 \\
3\end{array}$ & $\begin{array}{r}19 \\
9 \\
-1\end{array}$ & $\begin{array}{r}28 \\
18 \\
8\end{array}$ \\
\hline$W 111 \operatorname{cox}$ & 1280 & $32^{\circ} 15^{\prime} \mathrm{N}$ & $109^{\circ} 49^{\prime} \mathrm{H}$ & IVBcw & $\begin{array}{l}\text { Maximum } \\
\text { Mean } \\
\text { Minimum }\end{array}$ & $\begin{array}{r}15 \\
7 \\
-1\end{array}$ & $\begin{array}{r}17 \\
8 \\
00\end{array}$ & $\begin{array}{r}22 \\
12 \\
2\end{array}$ & $\begin{array}{r}25 \\
14 \\
3\end{array}$ & $\begin{array}{r}29 \\
18 \\
7\end{array}$ & $\begin{array}{l}35 \\
24 \\
12\end{array}$ & $\begin{array}{l}35 \\
26 \\
17\end{array}$ & $\begin{array}{l}34 \\
26 \\
16\end{array}$ & $\begin{array}{l}31 \\
22 \\
13\end{array}$ & $\begin{array}{r}27 \\
17 \\
6\end{array}$ & $\begin{array}{r}20 \\
10 \\
1\end{array}$ & $\begin{array}{r}13 \\
5 \\
-3\end{array}$ & $\begin{array}{r}26 \\
15 \\
5\end{array}$ \\
\hline Wittmann & 510 & $33^{\circ} 47^{\prime} \mathrm{N}$ & $112^{\circ} 32^{\prime} \mathrm{W}$ & IIIAcw & $\begin{array}{l}\text { Maximum } \\
\text { Mean } \\
\text { MIn Imum }\end{array}$ & $\begin{array}{r}18 \\
10 \\
2\end{array}$ & $\begin{array}{r}20 \\
12 \\
4\end{array}$ & $\begin{array}{r}22 \\
14 \\
5\end{array}$ & $\begin{array}{l}28 \\
19 \\
10\end{array}$ & $\begin{array}{l}33 \\
24 \\
14\end{array}$ & $\begin{array}{l}37 \\
28 \\
18\end{array}$ & $\begin{array}{l}41 \\
33 \\
25\end{array}$ & $\begin{array}{l}39 \\
31 \\
24\end{array}$ & $\begin{array}{l}36 \\
28 \\
20\end{array}$ & $\begin{array}{l}31 \\
33 \\
14\end{array}$ & $\begin{array}{l}23 \\
15 \\
6\end{array}$ & $\begin{array}{r}19 \\
11 \\
3\end{array}$ & $\begin{array}{l}29 \\
21 \\
12\end{array}$ \\
\hline
\end{tabular}


Table A.1.-- - Cont inued.

\begin{tabular}{|c|c|c|c|c|c|c|c|c|c|c|c|c|c|c|c|c|c|c|}
\hline \multirow[b]{2}{*}{ Station } & \multirow{2}{*}{$\begin{array}{l}\text { Elevation } \\
\text { In Meters }\end{array}$} & \multirow[b]{2}{*}{ Lat ltude } & \multirow[b]{2}{*}{ Longltude } & \multirow[b]{2}{*}{ Class } & \multirow[b]{2}{*}{ - } & \multirow[b]{2}{*}{ J } & \multirow[b]{2}{*}{$\mathbf{F}$} & \multirow[b]{2}{*}{$\bar{M}$} & \multirow[b]{2}{*}{$A$} & \multicolumn{6}{|c|}{ Average Monthly Temperature ${ }^{\circ}$} & \multirow{2}{*}{ N } & \multirow[b]{2}{*}{$\bar{D}$} & \multirow[b]{2}{*}{ Annual } \\
\hline & & & & & & & & & & $M$ & $\mathbf{J}$ & $\mathbf{J}$ & $A$ & $\mathbf{s}$ & 0 & & & \\
\hline Youngstown & 340.5 & $33^{\circ} 36^{\prime} \mathrm{N}$ & $112^{\circ} 18^{\circ} \mathrm{W}$ & I I IAcW & $\begin{array}{l}\text { Maximum } \\
\text { Mean } \\
\text { Min Imum }\end{array}$ & $\begin{array}{r}19 \\
10 \\
2\end{array}$ & $\begin{array}{r}22 \\
13 \\
4\end{array}$ & $\begin{array}{r}25 \\
15 \\
6\end{array}$ & $\begin{array}{r}29 \\
19 \\
9\end{array}$ & $\begin{array}{l}34 \\
24 \\
13\end{array}$ & $\begin{array}{l}39 \\
29 \\
18\end{array}$ & $\begin{array}{l}41 \\
33 \\
24\end{array}$ & $\begin{array}{l}40 \\
31 \\
23\end{array}$ & $\begin{array}{l}37 \\
28 \\
18\end{array}$ & $\begin{array}{l}31 \\
21 \\
12\end{array}$ & $\begin{array}{r}25 \\
15 \\
6\end{array}$ & $\begin{array}{r}20 \\
11 \\
2\end{array}$ & $\begin{array}{l}30 \\
21 \\
11\end{array}$ \\
\hline Yuma & $42^{\circ}$ & $32^{\circ} 40^{\circ} \mathrm{N}$ & $114^{\circ} 36^{\prime} \mathrm{W}$ & I I IAcw & $\begin{array}{l}\text { Maximum } \\
\text { Mean } \\
\text { MInImun }\end{array}$ & $\begin{array}{r}20 \\
12 \\
4\end{array}$ & $\begin{array}{r}22 \\
15 \\
7\end{array}$ & $\begin{array}{l}26 \\
18 \\
10\end{array}$ & $\begin{array}{l}31 \\
23 \\
15\end{array}$ & $\begin{array}{l}34 \\
26 \\
18\end{array}$ & $\begin{array}{l}40 \\
31 \\
22\end{array}$ & $\begin{array}{l}41 \\
33 \\
25\end{array}$ & $\begin{array}{l}40 \\
33 \\
25\end{array}$ & $\begin{array}{l}40 \\
31 \\
23\end{array}$ & $\begin{array}{l}33 \\
24 \\
16\end{array}$ & $\begin{array}{r}24 \\
17 \\
9\end{array}$ & $\begin{array}{r}21 \\
14 \\
7\end{array}$ & $\begin{array}{l}31 \\
23 \\
15\end{array}$ \\
\hline
\end{tabular}

1/Source: Green (1962), Green and Kangieses (1967), Conway and Liston (1974), Sellers and Hill (1974), U.S. Environmental Data Service (1980), and U.S. Weather Bureau (1980). 
Table A.2. Average monthly temperature of selected stations in Sonora, Mexico. 1 /

\begin{tabular}{|c|c|c|c|c|c|c|c|c|c|c|c|c|c|c|c|c|c|c|}
\hline \multirow[b]{2}{*}{ Station } & \multirow{2}{*}{$\begin{array}{l}\text { Elevation } \\
\text { In Meters }\end{array}$} & \multirow[b]{2}{*}{ Lat itude } & \multirow[b]{2}{*}{ Longitude } & \multirow[b]{2}{*}{ Class } & & \multicolumn{13}{|c|}{ Average Ionthly Temperature ${ }^{\circ} \mathrm{C}$} \\
\hline & & & & & & $\mathbf{J}$ & $\mathbf{F}$ & $\mathbf{M}$ & A & $M$ & $\mathrm{~J}$ & $\mathbf{J}$ & A & $\mathbf{s}$ & 0 & $\mathbf{N}$ & D & Annual \\
\hline Alamos & 389 & $27^{\circ} 02^{\prime} \mathrm{N}$ & $108^{\circ} 57^{\prime} \mathrm{W}$ & IIAw & $\begin{array}{l}\text { Maximum } \\
\text { Mean } \\
\text { Minimum }\end{array}$ & $\begin{array}{r}25 \\
17 \\
9\end{array}$ & $\begin{array}{r}27 \\
18 \\
9\end{array}$ & $\begin{array}{l}30 \\
20 \\
10\end{array}$ & $\begin{array}{l}34 \\
23 \\
13\end{array}$ & $\begin{array}{l}37 \\
27 \\
16\end{array}$ & $\begin{array}{l}39 \\
30 \\
21\end{array}$ & $\begin{array}{l}36 \\
29 \\
22 .\end{array}$ & $\begin{array}{l}34 \\
28 \\
22\end{array}$ & $\begin{array}{l}35 \\
28 \\
21\end{array}$ & $\begin{array}{l}33 \\
25 \\
17\end{array}$ & $\begin{array}{l}30 \\
21 \\
12\end{array}$ & $\begin{array}{r}26 \\
18 \\
9\end{array}$ & $\begin{array}{l}32 \\
24 \\
15\end{array}$ \\
\hline Altar & 397 & $30^{\circ} 43^{\prime} \mathrm{N}$ & $111^{\circ} 44^{\prime} \mathrm{W}$ & IIIACW & $\begin{array}{l}\text { Maximum } \\
\text { Mean } \\
\text { Minimum }\end{array}$ & $\begin{array}{r}22 \\
12 \\
2\end{array}$ & $\begin{array}{r}24 \\
14 \\
4\end{array}$ & $\begin{array}{r}27 \\
16 \\
5\end{array}$ & $\begin{array}{r}30 \\
19 \\
8\end{array}$ & $\begin{array}{l}36 \\
24 \\
13\end{array}$ & $\begin{array}{l}39 \\
28 \\
17\end{array}$ & $\begin{array}{l}40 \\
31 \\
23\end{array}$ & $\begin{array}{l}39 \\
31 \\
23\end{array}$ & $\begin{array}{l}37 \\
28 \\
19\end{array}$ & $\begin{array}{l}34 \\
23 \\
13\end{array}$ & $\begin{array}{r}26 \\
17 \\
7\end{array}$ & $\begin{array}{r}22 \\
12 \\
3\end{array}$ & $\begin{array}{l}31 \\
21 \\
11\end{array}$ \\
\hline Arivech1 & 556 & $28^{\circ} 56^{\prime} \mathrm{N}$ & $109^{\circ} 11 ' \mathrm{~W}$ & IIIAcW & $\begin{array}{l}\text { Maximum } \\
\text { Mean } \\
\text { Minimum }\end{array}$ & $\begin{array}{r}23 \\
13 \\
4\end{array}$ & $\begin{array}{r}26 \\
14 \\
5\end{array}$ & $\begin{array}{r}28 \\
18 \\
7\end{array}$ & $\begin{array}{l}33 \\
22 \\
11\end{array}$ & $\begin{array}{l}37 \\
26 \\
15\end{array}$ & $\begin{array}{l}40 \\
30 \\
21\end{array}$ & $\begin{array}{l}37{ }^{\circ} \\
29 \\
22\end{array}$ & $\begin{array}{l}36 \\
28 \\
21\end{array}$ & $\begin{array}{l}36 \\
28 \\
20\end{array}$ & $\begin{array}{l}34 \\
24 \\
14 .\end{array}$ & $\begin{array}{r}27 \\
18 \\
9\end{array}$ & $\begin{array}{r}23 \\
14 \\
4\end{array}$ & $\begin{array}{l}32 \\
22 \\
13\end{array}$ \\
\hline At 11 & 306 & $30^{\circ} 50^{\prime} \mathrm{N}$ & $111^{\circ} 34^{\prime} \mathrm{W}$ & IIIACW & $\begin{array}{l}\text { Maximum } \\
\text { Mean } \\
\text { Minimum }\end{array}$ & $\begin{array}{r}21 \\
12 \\
3\end{array}$ & $\begin{array}{r}23 \\
14 \\
4\end{array}$ & $\begin{array}{r}25 \\
15 \\
6\end{array}$ & $\begin{array}{r}29 \\
19 \\
9\end{array}$ & $\begin{array}{l}34 \\
23 \\
12\end{array}$ & $\begin{array}{l}38 \\
27 \\
17\end{array}$ & $\begin{array}{l}38 \\
31 \\
23\end{array}$ & $\begin{array}{l}36 \\
29 \\
22\end{array}$ & $\begin{array}{l}36 \\
28 \\
19\end{array}$ & $\begin{array}{l}32 \\
23 \\
14\end{array}$ & $\begin{array}{r}26 \\
16 \\
7\end{array}$ & $\begin{array}{r}22 \\
13 \\
4\end{array}$ & $\begin{array}{l}30 \\
21 \\
11\end{array}$ \\
\hline Baviacora & 620 & $29^{\circ} 43^{\prime} \mathrm{N}$ & $110^{\circ} 09^{\prime} \mathrm{W}$ & IIAw & $\begin{array}{l}\text { Maximum } \\
\text { Hean } \\
\text { Minimum }\end{array}$ & $\begin{array}{r}20 \\
13 \\
7\end{array}$ & $\begin{array}{r}22 \\
16 \\
9\end{array}$ & $\begin{array}{l}26 \\
19 \\
12\end{array}$ & $\begin{array}{l}29 \\
23 \\
16\end{array}$ & $\begin{array}{l}33 \\
26 \\
20\end{array}$ & $\begin{array}{l}37 \\
31 \\
25\end{array}$ & $\begin{array}{l}35 \\
31 \\
26\end{array}$ & $\begin{array}{l}34 \\
30 \\
25\end{array}$ & $\begin{array}{l}34 \\
29 \\
24\end{array}$ & $\begin{array}{l}30 \\
24 \\
18\end{array}$ & $\begin{array}{l}25 \\
18 \\
12\end{array}$ & $\begin{array}{r}20 \\
14 \\
8\end{array}$ & $\begin{array}{l}29 \\
23 \\
17\end{array}$ \\
\hline Bavispe & 902 & $30^{\circ} 29^{\prime} \mathrm{N}$ & $108^{\circ} 57^{\prime} \mathrm{W}$ & IIIACW & $\begin{array}{l}\text { Maximum } \\
\text { Mean } \\
\text { MInImum }\end{array}$ & $\begin{array}{r}19 \\
11 \\
3\end{array}$ & $\begin{array}{r}22 \\
13 \\
4\end{array}$ & $\begin{array}{r}25 \\
16 \\
7\end{array}$ & $\begin{array}{l}30 \\
21 \\
11\end{array}$ & $\begin{array}{l}: 35 \\
25 \\
15\end{array}$ & $\begin{array}{l}39 \\
30 \\
20\end{array}$ & $\begin{array}{l}37 \\
30 \\
22\end{array}$ & $\begin{array}{l}36 \\
29 \\
22\end{array}$ & $\begin{array}{l}36 \\
27 \\
19\end{array}$ & $\begin{array}{l}31 \\
22 \\
13\end{array}$ & $\begin{array}{r}25 \\
15 \\
6\end{array}$ & $\begin{array}{r}20 \\
11 \\
3\end{array}$ & $\begin{array}{l}30 \\
21 \\
12\end{array}$ \\
\hline Cananea & 1585 & $30^{\circ} 58^{\prime} \mathrm{N}$ & $110^{\circ} 17^{\prime} \mathrm{W}$ & IIICcw & $\begin{array}{l}\text { Maximum } \\
\text { Mean } \\
\text { Minimum }\end{array}$ & $\begin{array}{r}14 \\
8 \\
2\end{array}$ & $\begin{array}{r}16 \\
10 \\
4\end{array}$ & $\begin{array}{r}17 \\
11 \\
4\end{array}$ & $\begin{array}{r}23 \\
15 \\
8\end{array}$ & $\begin{array}{l}27 \\
19 \\
12\end{array}$ & $\begin{array}{l}31 \\
24 \\
17\end{array}$ & $\begin{array}{l}30 \\
24 \\
17\end{array}$ & $\begin{array}{l}29 \\
23 \\
17\end{array}$ & $\begin{array}{l}28 \\
22 \\
15\end{array}$ & $\begin{array}{l}24 \\
18 \\
11\end{array}$ & $\begin{array}{r}18 \\
13 \\
7\end{array}$ & $\begin{array}{r}15 \\
9 \\
3\end{array}$ & $\begin{array}{l}23 \\
16 \\
10\end{array}$ \\
\hline Carbo & 464.4 & $29^{\circ} 41^{\prime} \mathrm{N}$ & $110^{\circ} 57^{\prime} \mathrm{W}$ & IIAw & $\begin{array}{l}\text { Maximum } \\
\text { Mean } \\
\text { Minimum }\end{array}$ & $\begin{array}{r}23 \\
14 \\
5\end{array}$ & $\begin{array}{r}25 \\
16 \\
6\end{array}$ & $\begin{array}{r}28 \\
18 \\
8\end{array}$ & $\begin{array}{l}31 \\
21 \\
10\end{array}$ & $\begin{array}{l}34 \\
24 \\
14\end{array}$ & $\begin{array}{l}38 \\
28 \\
18\end{array}$ & $\begin{array}{l}39 \\
31 \\
23\end{array}$ & $\begin{array}{l}35 \\
29 \\
22\end{array}$ & $\begin{array}{l}35 \\
27 \\
19\end{array}$ & $\begin{array}{l}34 \\
24 \\
15\end{array}$ & $\begin{array}{l}29 \\
20 \\
11\end{array}$ & $\begin{array}{r}24 \\
15 \\
6\end{array}$ & $\begin{array}{l}33 \\
23 \\
13\end{array}$ \\
\hline $\begin{array}{l}\text { E1 Oregano } \\
\text { Hermos } 1110\end{array}$ & 282 & $29^{\circ} 14^{\prime} \mathrm{N}$ & $110^{\circ} 43^{\prime} \mathrm{W}$ & IIAw & $\begin{array}{l}\text { Maximum } \\
\text { Mean } \\
\text { Minimum }\end{array}$ & $\begin{array}{r}28 \\
17 \\
7\end{array}$ & $\begin{array}{r}30 \\
19 \\
8\end{array}$ & $\begin{array}{l}32 \\
21 \\
11\end{array}$ & $\begin{array}{l}35 \\
25 \\
14 .\end{array}$ & $\begin{array}{l}39 \\
28 \\
16 .\end{array}$ & $\begin{array}{l}43 \\
33 \\
23\end{array}$ & $\begin{array}{l}42 \\
35 \\
28\end{array}$ & $\begin{array}{l}41 \\
34 \\
27\end{array}$ & $\begin{array}{l}42 \\
33 \\
25\end{array}$ & $\begin{array}{l}38 \\
28 \\
18\end{array}$ & $\begin{array}{l}33 \\
22 \\
11\end{array}$ & $\begin{array}{r}29 \\
18 \\
8\end{array}$ & $\begin{array}{l}36 \\
26 \\
16\end{array}$ \\
\hline
\end{tabular}


Table A.2.-- Continued.

\begin{tabular}{|c|c|c|c|c|c|c|c|c|c|c|c|c|c|c|c|c|c|c|}
\hline \multirow[b]{2}{*}{ Station } & \multirow{2}{*}{$\begin{array}{l}\text { Elevation } \\
\text { in Meters }\end{array}$} & \multirow[b]{2}{*}{ Lat Itude } & \multirow[b]{2}{*}{ Longltude } & \multirow[b]{2}{*}{ cliass } & & \multirow[b]{2}{*}{$\bar{J}$} & \multirow[b]{2}{*}{$\mathbf{F}$} & \multirow[b]{2}{*}{$M$} & \multicolumn{7}{|c|}{ Average Monthly Temperature ${ }^{\circ} \mathrm{C}$} & \multirow[b]{2}{*}{$N$} & \multirow[b]{2}{*}{ D } & \multirow[b]{2}{*}{ Annual } \\
\hline & & & & & & & & & $\mathbf{A}$ & $M$ & $\mathbf{J}$ & $\mathrm{J}$ & $A$ & $s$ & 0 & & & \\
\hline Etchojoa & 13 & $26^{\circ} 55^{\prime} \mathrm{N}$ & $109^{\circ} 38^{\prime} \mathrm{W}$ & IIAw & $\begin{array}{l}\text { - Maximum } \\
\text { Mean } \\
\text { Minimum }\end{array}$ & $\begin{array}{r}25 \\
16 \\
7\end{array}$ & $\begin{array}{r}26 \\
17 \\
7\end{array}$ & $\begin{array}{r}28 \\
18 \\
9\end{array}$ & $\begin{array}{l}31 \\
21 \\
11\end{array}$ & $\begin{array}{l}34 \\
24 \\
14\end{array}$ & $\begin{array}{l}36 \\
28 \\
20\end{array}$ & $\begin{array}{l}36 \\
30 \\
24\end{array}$ & $\begin{array}{l}36 \\
30 \\
23\end{array}$ & $\begin{array}{l}37 \\
30 \\
23\end{array}$ & $\begin{array}{l}34 \\
26 \\
18\end{array}$ & $\begin{array}{l}30 \\
21 \\
11\end{array}$ & $\begin{array}{r}26 \\
17 \\
8\end{array}$ & $\begin{array}{l}31 \\
23 \\
15\end{array}$ \\
\hline Flex Gomez & 614 & $29^{\circ} 50^{\prime} \mathrm{N}$ & $111^{\circ} 31^{\prime} \mathrm{W}$ & IIIACW & $\begin{array}{l}\text { Maximum } \\
\text { Mean } \\
\text { Minimum }\end{array}$ & $\begin{array}{r}22 \\
13 \\
4\end{array}$ & $\begin{array}{r}23 \\
14 \\
5\end{array}$ & $\begin{array}{r}25 \\
16 \\
6\end{array}$ & $\begin{array}{r}28 \\
19 \\
9\end{array}$ & $\begin{array}{l}34 \\
22 \\
10\end{array}$ & $\begin{array}{l}36 \\
26 \\
16\end{array}$ & $\begin{array}{l}37 \\
29 \\
20\end{array}$ & $\begin{array}{l}36 \\
27 \\
18\end{array}$ & $\begin{array}{l}34 \\
26 \\
18\end{array}$ & $\begin{array}{l}32 \\
24 \\
15\end{array}$ & $\begin{array}{r}26 \\
15 \\
4\end{array}$ & $\begin{array}{r}22 \\
12 \\
2\end{array}$ & $\begin{array}{l}30 \\
20 \\
11\end{array}$ \\
\hline Fronterar & 1127 & $30^{\circ} 56^{\prime} \mathrm{N}$ & $109^{\circ} 30^{\circ} \mathrm{W}$ & VACW & $\begin{array}{l}\text { Maximum } \\
\text { Mean } \\
\text { Minimum }\end{array}$ & $\begin{array}{r}18 \\
8 \\
-3\end{array}$ & $\begin{array}{l}21 \\
10 \\
-1\end{array}$ & $\begin{array}{r}24 \\
13 \\
2\end{array}$ & $\begin{array}{r}29 \\
17 \\
6\end{array}$ & $\begin{array}{r}33 \\
21 \\
9\end{array}$ & $\begin{array}{l}37 \\
26 \\
15\end{array}$ & $\begin{array}{l}36 \\
27 \\
18\end{array}$ & $\begin{array}{l}35 \\
27 \\
18\end{array}$ & $\begin{array}{l}35 \\
24 \\
14\end{array}$ & $\begin{array}{r}30 \\
18 \\
6\end{array}$ & $\begin{array}{l}24 \\
12 \\
00\end{array}$ & $\begin{array}{r}20 \\
9 \\
-3\end{array}$ & $\begin{array}{r}28 \\
17 \\
7\end{array}$ \\
\hline Guaymas & 8 & $27^{\circ} 5 S^{\prime} \mathrm{N}$ & $110^{\circ} 54^{\prime} \mathrm{W}$ & IAw & $\begin{array}{l}\text { Maximum } \\
\text { Mean } \\
\text { MinImum }\end{array}$ & $\begin{array}{l}23 \\
18 \\
14\end{array}$ & $\begin{array}{l}25 \\
19 \\
14\end{array}$ & $\begin{array}{l}26 \\
21 \\
16\end{array}$ & $\begin{array}{l}29 \\
23 \\
18\end{array}$ & $\begin{array}{l}32 \\
27 \\
21\end{array}$ & $\begin{array}{l}34 \\
29 \\
25\end{array}$ & $\begin{array}{l}35 \\
31 \\
28\end{array}$ & $\begin{array}{l}35 \\
31 \\
27\end{array}$ & $\begin{array}{l}35 \\
31 \\
27\end{array}$ & $\begin{array}{l}32 \\
28 \\
23\end{array}$ & $\begin{array}{l}28 \\
23 \\
18\end{array}$ & $\begin{array}{l}24 \\
19 \\
15\end{array}$ & $\begin{array}{l}30 \\
25 \\
20\end{array}$ \\
\hline Hermost11o & 237 & $29^{\circ} \mathrm{S}^{\prime} \mathrm{N}$ & $110^{\circ} 57^{\prime} \mathrm{W}$ & IIAW & $\begin{array}{l}\text { Maximum } \\
\text { Mean } \\
\text { Min Imum }\end{array}$ & $\begin{array}{c}24 \\
16 \\
9\end{array}$ & $\begin{array}{l}26 \\
17 \\
10\end{array}$ & $\begin{array}{l}28 \\
19 \\
11\end{array}$ & $\begin{array}{l}32 \\
24 \\
14\end{array}$ & $\begin{array}{l}36 \\
27 \\
18\end{array}$ & $\begin{array}{l}40 \\
31 \\
22\end{array}$ & $\begin{array}{l}40 \\
33 \\
25\end{array}$ & $\begin{array}{l}39 \\
32 \\
25\end{array}$ & $\begin{array}{l}38 \\
31 \\
24\end{array}$ & $\begin{array}{l}35 \\
27 \\
18\end{array}$ & $\begin{array}{l}29 \\
21 \\
13\end{array}$ & $\begin{array}{r}24 \\
17 \\
9\end{array}$ & $\begin{array}{l}32 \\
24 \\
16\end{array}$ \\
\hline Imur 1s & 826 & $30^{\circ} 47^{\prime} \mathrm{N}$ & $110^{\circ} 52^{\prime} \mathrm{W}$ & IIIẠcW & $\begin{array}{l}\text { Maximum } \\
\text { Mean } \\
\text { Minimum }\end{array}$ & $\begin{array}{r}21 \\
12 \\
3\end{array}$ & $\begin{array}{r}24 \\
14 \\
4\end{array}$ & $\begin{array}{r}24 \\
15 \\
5\end{array}$ & $\begin{array}{r}29 \\
19 \\
8\end{array}$ & $\begin{array}{l}34 \\
22 \\
11\end{array}$ & $\begin{array}{l}38 \\
27 \\
16\end{array}$ & $\begin{array}{l}38 \\
29 \\
21\end{array}$ & $\begin{array}{l}36 \\
28 \\
20\end{array}$ & $\begin{array}{l}36 \\
27 \\
17\end{array}$ & $\begin{array}{l}32 \\
22 \\
12\end{array}$ & $\begin{array}{r}27 \\
16 \\
6\end{array}$ & $\begin{array}{r}23 \\
13 \\
3\end{array}$ & $\begin{array}{l}30 \\
20 \\
10\end{array}$ \\
\hline La Colorado & 500 & $28^{\circ} 47^{\prime} \mathrm{N}$ & $110^{\circ} 34^{\prime} \mathrm{W}$ & IIICcw & $\begin{array}{l}\text { Maximum } \\
\text { Mean } \\
\text { Minimum }\end{array}$ & $\begin{array}{r}19 \\
12 \\
4\end{array}$ & $\begin{array}{r}21 \\
13 \\
6\end{array}$ & $\begin{array}{r}23 \\
15 \\
7\end{array}$ & $\begin{array}{r}27 \\
18 \\
9\end{array}$ & $\begin{array}{l}31 \\
22 \\
13\end{array}$ & $\begin{array}{l}34 \\
25 \\
17\end{array}$ & $\begin{array}{l}34 \\
27 \\
19\end{array}$ & $\begin{array}{l}32 \\
26 \\
20\end{array}$ & $\begin{array}{l}32 \\
25 \\
18\end{array}$ & $\begin{array}{l}30 \\
22 \\
14\end{array}$ & $\begin{array}{r}25 \\
17 \\
9\end{array}$ & $\begin{array}{r}19 \\
12 \\
4\end{array}$ & $\begin{array}{l}28 \\
21 \\
13\end{array}$ \\
\hline $\begin{array}{l}\text { La Dura } \\
\text { Rosario }\end{array}$ & 177 & $28^{\circ} 23^{\prime} \mathrm{N}$ & $109^{\circ} 33^{\prime} \mathrm{W}$ & IIAw & $\begin{array}{l}\text { Maximum } \\
\text { Mean } \\
\text { Minimum }\end{array}$ & $\begin{array}{r}27 \\
17 \\
6\end{array}$ & $\begin{array}{r}29 \\
18 \\
7\end{array}$ & $\begin{array}{r}31 \\
20 \\
9\end{array}$ & $\begin{array}{l}36 \\
24 \\
12\end{array}$ & $\begin{array}{l}39 \\
29 \\
16\end{array}$ & $\begin{array}{l}41 \\
31 \\
22\end{array}$ & $\begin{array}{l}39 \\
31 \\
23\end{array}$ & $\begin{array}{l}37 \\
30 \\
23\end{array}$ & $\begin{array}{l}39 \\
30 \\
21\end{array}$ & $\begin{array}{l}37 \\
26 \\
16\end{array}$ & $\begin{array}{r}33 \\
21 \\
9\end{array}$ & $\begin{array}{r}28 \\
17 \\
8\end{array}$ & $\begin{array}{l}35 \\
24 \\
14\end{array}$ \\
\hline $\begin{array}{l}\text { Minas Nuevas } \\
\text { Alamos }\end{array}$ & 520 & $27^{\circ} 03^{\prime} \mathrm{N}$ & $109^{\circ} 01^{\prime} w$ & IIAW & $\begin{array}{l}\text { Maximum } \\
\text { Mean } \\
\text { Minimum }\end{array}$ & $\begin{array}{r}26 \\
17 \\
9\end{array}$ & $\begin{array}{r}27 \\
18 \\
9\end{array}$ & $\begin{array}{l}30 \\
20 \\
10\end{array}$ & $\begin{array}{l}34 \\
23 \\
13\end{array}$ & $\begin{array}{l}36 \\
26 \\
16\end{array}$ & $\begin{array}{l}38 \\
29 \\
20\end{array}$ & $\begin{array}{l}36 \\
29 \\
22\end{array}$ & $\begin{array}{r}34 \\
28 \\
22\end{array}$ & $\begin{array}{l}34 \\
28 \\
21\end{array}$ & $\begin{array}{l}34 \\
25 \\
17\end{array}$ & $\begin{array}{l}30 \\
21 \\
13\end{array}$ & $\begin{array}{l}30 \\
20 \\
10\end{array}$ & $\begin{array}{l}32 \\
24 \\
15\end{array}$ \\
\hline
\end{tabular}


Table A.2. - - Cont inued.

\begin{tabular}{|c|c|c|c|c|c|c|c|c|c|c|c|c|c|c|c|c|c|c|}
\hline \multirow[b]{2}{*}{ Station } & \multirow{2}{*}{$\begin{array}{l}\text { Elevation } \\
\text { in lieters }\end{array}$} & \multirow[b]{2}{*}{ Latitude } & \multirow[b]{2}{*}{ Longitude } & \multirow[b]{2}{*}{ Class } & & \multicolumn{10}{|c|}{ Average Monthly Temperature ${ }^{\circ} \mathrm{C}$} & & \multirow[b]{2}{*}{ D } & \multirow[b]{2}{*}{ Annual } \\
\hline & & & & & & $\bar{J}$ & $\mathbf{F}$ & $M$ & . A & $M$ & $\mathbf{J}$ & $\mathrm{J}$ & A. & $\mathbf{s}$ & 0 & $\bar{N}$ & & \\
\hline Moctezuma & 677 & $29^{\circ} 48^{\prime} \mathrm{N}$ & $109^{\circ} 42^{\prime} \mathrm{W}$ & I I IAcW & $\begin{array}{l}\text { Maximum } \\
\text { Mean } \\
\text { :Iin1mum }\end{array}$ & $\begin{array}{r}22 \\
12 \\
2\end{array}$ & $\begin{array}{r}24 \\
14 \\
4\end{array}$ & $\begin{array}{r}27 \\
16 \\
6\end{array}$ & $\begin{array}{r}32 \\
21 \\
9\end{array}$ & $\begin{array}{l}36 \\
25 \\
13\end{array}$ & $\begin{array}{l}40 \\
30 \\
20\end{array}$ & $\begin{array}{l}38 \\
30 \\
22\end{array}$ & $\begin{array}{l}37 \\
29 \\
22\end{array}$ & $\begin{array}{l}36 \\
28 \\
19\end{array}$ & $\begin{array}{l}33 \\
23 \\
13\end{array}$ & $\begin{array}{r}27 \\
16 \\
5\end{array}$ & $\begin{array}{r}24 \\
13 \\
2\end{array}$ & $\begin{array}{l}31 \\
21 \\
11\end{array}$ \\
\hline $\begin{array}{l}\text { Mulatas } \\
\text { Sahuaripa }\end{array}$ & 1156 & $28^{\circ} 38^{\prime} \mathrm{N}$ & $108^{\circ} 45^{\prime} \mathrm{W}$ & IIIBCW & $\begin{array}{l}\text { Maximum } \\
\text { Mean } \\
\text { Min1mum }\end{array}$ & $\begin{array}{r}20 \\
12 \\
4\end{array}$ & $\begin{array}{r}22 \\
14 \\
5\end{array}$ & $\begin{array}{r}25 \\
16 \\
7\end{array}$ & $\begin{array}{l}28 \\
19 \\
11\end{array}$ & $\begin{array}{l}31 \\
22 \\
14\end{array}$ & $\begin{array}{l}34 \\
27 \\
19\end{array}$ & $\begin{array}{l}32 \\
25 \\
18\end{array}$ & $\begin{array}{l}31 \\
25 \\
18\end{array}$ & $\begin{array}{l}32 \\
24 \\
18\end{array}$ & $\begin{array}{l}30 \\
21 \\
12\end{array}$ & $\begin{array}{r}25 \\
16 \\
7\end{array}$ & $\begin{array}{r}21 \\
12 \\
4\end{array}$ & $\begin{array}{l}28 \\
19 \\
11\end{array}$ \\
\hline $\begin{array}{l}\text { Nacor1 Grande } \\
\text { Villa Pesquelra }\end{array}$ & 634 & $29^{\circ} 04^{\prime} \mathrm{N}$ & $110^{\circ} 03^{\prime} \mathrm{W}$ & Iw & $\begin{array}{l}\text { Maxinum } \\
\text { Mlean } \\
\text { Minimum }\end{array}$ & $\begin{array}{l}20 \\
17 \\
14\end{array}$ & $\begin{array}{l}22 \\
18 \\
14\end{array}$ & $\begin{array}{l}24 \\
21 \\
18\end{array}$ & $\begin{array}{l}28 \\
25 \\
21\end{array}$ & $\begin{array}{l}31 \\
27 \\
23\end{array}$ & $\begin{array}{l}35 \\
31 \\
27\end{array}$ & $\begin{array}{l}33 \\
30 \\
27\end{array}$ & $\begin{array}{l}33 \\
29 \\
26\end{array}$ & $\begin{array}{l}33 \\
29 \\
25\end{array}$ & $\begin{array}{l}29 \\
26 \\
22\end{array}$ & $\begin{array}{l}25 \\
21 \\
18\end{array}$ & $\begin{array}{l}22 \\
18 \\
15\end{array}$ & $\begin{array}{l}28 \\
24 \\
21\end{array}$ \\
\hline Navajoa & 47.8 & $27^{\circ} 066^{\prime}$ & $109^{\circ} 26^{\prime} \mathrm{W}$ & IAw & $\begin{array}{l}\text { Maximum } \\
\text { Mean } \\
\text { Minimum }\end{array}$ & $\begin{array}{l}26 \\
19 \\
11\end{array}$ & $\begin{array}{l}27 \\
19 \\
11\end{array}$ & $\begin{array}{l}30 \\
21 \\
13\end{array}$ & $\begin{array}{l}33 \\
24 \\
15\end{array}$ & $\begin{array}{l}36 \\
28 \\
19\end{array}$ & $\begin{array}{l}38 \\
31 \\
24\end{array}$ & $\begin{array}{l}38 \\
33 \\
27\end{array}$ & $\begin{array}{l}37 \\
32 \\
27\end{array}$ & $\begin{array}{l}37 \\
32 \\
26\end{array}$ & $\begin{array}{l}35 \\
28 \\
21\end{array}$ & $\begin{array}{l}30 \\
23 \\
15\end{array}$ & $\begin{array}{l}27 \\
20 \\
12\end{array}$ & $\begin{array}{l}33 \\
26 \\
19\end{array}$ \\
\hline $\begin{array}{l}\text { Nuri } \\
\text { Rosario }\end{array}$ & 450 & $28^{\circ} 02^{\prime} \mathrm{N}$ & $109^{\circ} 23^{\prime} \mathrm{W}$ & IIAw & $\begin{array}{l}\text { Maximum } \\
\text { Mean } \\
\text { Minimum }\end{array}$ & $\begin{array}{r}24 \\
15 \\
+6\end{array}$ & $\begin{array}{r}26 \\
17 \\
7\end{array}$ & $\begin{array}{l}29 \\
19 \\
10\end{array}$ & $\begin{array}{l}33 \\
23 \\
14\end{array}$ & $\begin{array}{l}36 \\
27 \\
18\end{array}$ & $\begin{array}{l}39 \\
31 \\
23\end{array}$ & $\begin{array}{l}36 \\
30 \\
24\end{array}$ & $\begin{array}{l}35 \\
29 \\
23\end{array}$ & $\begin{array}{l}35 \\
28 \\
21\end{array}$ & $\begin{array}{l}33 \\
25 \\
17\end{array}$ & $\begin{array}{l}29 \\
20 \\
10\end{array}$ & $\begin{array}{r}25 \\
16 \\
7\end{array}$ & $\begin{array}{l}32 \\
23 \\
15\end{array}$ \\
\hline Obregon & 39 & $27^{\circ} 29^{\prime} \mathrm{N}$ & $109^{\circ} 55^{\prime} \mathrm{W}$ & IIACW & $\begin{array}{l}\text { Maximum } \\
\text { Mean } \\
\text { Minimum }\end{array}$ & $\begin{array}{r}24 \\
15 \\
7\end{array}$ & $\begin{array}{r}24 \\
15 \\
7\end{array}$ & $\begin{array}{r}27 \\
17 \\
8\end{array}$ & $\begin{array}{l}31 \\
21 \\
11\end{array}$ & $\begin{array}{l}34 \\
25 \\
15\end{array}$ & $\begin{array}{l}36 \\
28 \\
20\end{array}$ & $\begin{array}{l}36 \\
30 \\
25\end{array}$ & $\begin{array}{l}35 \\
29 \\
24\end{array}$ & $\begin{array}{l}36 \\
29 \\
23\end{array}$ & $\begin{array}{l}34 \\
25 \\
18\end{array}$ & $\begin{array}{l}29 \\
20 \\
12\end{array}$ & $\begin{array}{r}24 \\
16 \\
9\end{array}$ & $\begin{array}{l}31 \\
23 \\
15\end{array}$ \\
\hline Opodepe & 596 & $29^{\circ} 54^{\prime} \mathrm{N}$ & $110^{\circ} 39^{\prime} \mathrm{W}$ & IIAcw & $\begin{array}{l}\text { Maximum } \\
\text { Mean } \\
\text { Minimum }\end{array}$ & $\begin{array}{r}22 \\
14 \\
6\end{array}$ & $\begin{array}{r}24 \\
15 \\
7\end{array}$ & $\begin{array}{r}25 \\
16 \\
8\end{array}$ & $\begin{array}{l}29 \\
20 \\
10\end{array}$ & $\begin{array}{l}33 \\
23 \\
14\end{array}$ & $\begin{array}{l}37 \\
28 \\
19\end{array}$ & $\begin{array}{l}36 \\
29 \\
22\end{array}$ & $\begin{array}{l}35 \\
28 \\
21\end{array}$ & $\begin{array}{l}35 \\
27 \\
19\end{array}$ & $\begin{array}{l}32 \\
24 \\
15\end{array}$ & $\begin{array}{l}26 \\
18 \\
10\end{array}$ & $\begin{array}{r}23 \\
15 \\
7\end{array}$ & $\begin{array}{l}30 \\
21 \\
13\end{array}$ \\
\hline Pitiquito & 286 & $30^{\circ} 41^{\prime} \mathrm{N}$ & $112^{\circ} 07^{\prime} \mathrm{W}$ & IIIACW & $\begin{array}{l}\text { Maximum } \\
\text { Mean } \\
\text { Minimum }\end{array}$ & $\begin{array}{r}21 \\
12 \\
2\end{array}$ & $\begin{array}{r}23 \\
13 \\
3\end{array}$ & $\begin{array}{r}26 \\
15 \\
5\end{array}$ & $\begin{array}{r}30 \\
18 \\
7\end{array}$ & $\begin{array}{l}35 \\
22 \\
10\end{array}$ & $\begin{array}{l}39 \\
27 \\
15\end{array}$ & $\begin{array}{l}40 \\
31 \\
22\end{array}$ & $\begin{array}{l}38 \\
30 \\
21\end{array}$ & $\begin{array}{l}37 \\
27 \\
18\end{array}$ & $\begin{array}{l}32 \\
22 \\
12\end{array}$ & $\begin{array}{r}26 \\
16 \\
6\end{array}$ & $\begin{array}{r}21 \\
12 \\
3\end{array}$ & $\begin{array}{l}31 \\
21 \\
10\end{array}$ \\
\hline $\begin{array}{l}\text { Presa } \\
\text { Cuauthemac }\end{array}$ & 390 & $30^{\circ} 52^{\circ} \mathrm{N}$ & $111^{\circ} 31^{\prime} \mathrm{W}$ & IIACW & $\begin{array}{l}\text { Maximum } \\
\text { Mean } \\
\text { Minimum }\end{array}$ & $\begin{array}{r}20 \\
13 \\
6\end{array}$ & $\begin{array}{r}22 \\
14 \\
6\end{array}$ & $\begin{array}{c}25 . \\
16 \\
8\end{array}$ & $\begin{array}{l}29 \\
20 \\
11\end{array}$ & $\begin{array}{l}33 \\
24 \\
14\end{array}$ & $\begin{array}{l}38 \\
28 \\
19\end{array}$ & $\begin{array}{l}37 \\
30 \\
22\end{array}$ & $\begin{array}{l}36 \\
29 \\
22\end{array}$ & $\begin{array}{l}36 \\
28 \\
20\end{array}$ & $\begin{array}{l}32 \\
23 \\
15\end{array}$ & $\begin{array}{r}25 \\
17 \\
9\end{array}$ & $\begin{array}{r}20 \\
13 \\
6\end{array}$ & $\begin{array}{l}29 \\
21 \\
13\end{array}$ \\
\hline
\end{tabular}


Table A.2.-- Continued. .

\begin{tabular}{|c|c|c|c|c|c|c|c|c|c|c|c|c|c|c|c|c|c|c|}
\hline \multirow[b]{2}{*}{ Station } & \multirow{2}{*}{$\begin{array}{l}\text { Elevation } \\
\text { in Meters }\end{array}$} & \multirow[b]{2}{*}{ Lat Itude } & \multirow[b]{2}{*}{ Longltude } & \multirow[b]{2}{*}{ Class } & & & \multicolumn{9}{|c|}{ Average Monthly Temperature ${ }^{\circ} \mathrm{C}$} \\
\hline & & & & & & $\bar{J}$ & $\bar{F}$ & $M$ & $\bar{A}$ & $\bar{M}$ & $\mathrm{~J}$ & $\mathbf{J}$ & $A$ & $\mathbf{S}$ & 0 & $\mathrm{~N}$ & D & $\overline{\text { Annual }}$ \\
\hline $\begin{array}{l}\text { Presa La } \\
\text { Angostura } \\
\text { Villa Hidalgo }\end{array}$ & 965 & $30^{\circ} 27^{\prime} \mathrm{N}$ & $109^{\circ} 23^{\circ} \mathrm{W}$ & IIACW & $\begin{array}{l}\text { Maximum } \\
\text { Mean } \\
\text { MIn Imum }\end{array}$ & $\begin{array}{r}17 \\
11 \\
5\end{array}$ & $\begin{array}{r}20 \\
14 \\
7\end{array}$ & $\begin{array}{l}23 \\
16 \\
10\end{array}$ & $\begin{array}{l}28 \\
21 \\
14\end{array}$ & $\begin{array}{l}33 \\
26 \\
19\end{array}$ & $\begin{array}{l}37 \\
30 \\
23\end{array}$ & $\begin{array}{l}36 \\
29 \\
22\end{array}$ & $\begin{array}{l}34 \\
28 \\
21\end{array}$ & $\begin{array}{l}34 \\
27 \\
21\end{array}$ & $\begin{array}{l}29 \\
23 \\
16\end{array}$ & $\begin{array}{l}22 \\
16 \\
10\end{array}$ & $\begin{array}{r}18 \\
12 \\
6\end{array}$ & $\begin{array}{l}27 \\
21 \\
14\end{array}$ \\
\hline $\begin{array}{l}\text { Puerto } \\
\text { Peaasco }\end{array}$ & 7 & $32^{\circ} 18^{\prime} \mathrm{N}$ & $113^{\circ} 33^{\prime} \mathrm{W}$ & II cw & $\begin{array}{l}\text { Max1mum } \\
\text { Mean } \\
\text { Min1mum }\end{array}$ & $\begin{array}{r}18 \\
12 \\
7\end{array}$ & $\begin{array}{r}23 \\
16 \\
9\end{array}$ & $\begin{array}{l}24 \\
17 \\
10\end{array}$ & $\begin{array}{l}26 \\
19 \\
12\end{array}$ & $\begin{array}{l}30 \\
22 \\
15\end{array}$ & $\begin{array}{l}31 \\
25 \\
19\end{array}$ & $\begin{array}{l}34 \\
27 \\
20\end{array}$ & $\begin{array}{l}35 \\
27 \\
20\end{array}$ & $\begin{array}{l}34 \\
27 \\
21\end{array}$ & $\begin{array}{l}32 \\
23 \\
14\end{array}$ & $\begin{array}{l}25 \\
18 \\
10\end{array}$ & $\begin{array}{r}21 \\
14 \\
8\end{array}$ & $\begin{array}{l}28 \\
21 \\
14\end{array}$ \\
\hline $\begin{array}{l}\text { Punta De } \\
\text { Augua }\end{array}$ & 214. & $28^{\circ} 26^{\prime} \mathrm{N}$ & $110^{\circ} 24^{\prime} \mathrm{W}$ & IIACW & $\begin{array}{l}\text { Maximum } \\
\text { Mean } \\
\text { Minimum }\end{array}$ & $\begin{array}{r}24 \\
15 \\
5\end{array}$ & $\begin{array}{r}26 \\
16 \\
6\end{array}$ & $\begin{array}{r}29 \\
19 \\
9\end{array}$ & $\begin{array}{l}33 \\
23 \\
13\end{array}$ & $\begin{array}{l}35 \\
25 \\
15\end{array}$ & $\begin{array}{l}38 \\
29 \\
20\end{array}$ & $\begin{array}{l}37 \\
30 \\
23\end{array}$ & $\begin{array}{l}36 \\
29 \\
23\end{array}$ & $\begin{array}{l}36 \\
28 \\
20\end{array}$ & $\begin{array}{l}34 \\
24 \\
15\end{array}$ & $\begin{array}{l}28 \\
19 \\
10\end{array}$ & $\begin{array}{r}24 \\
15 \\
5\end{array}$ & $\begin{array}{l}31 \\
23 \\
14\end{array}$ \\
\hline $\begin{array}{l}\text { San Bernardo } \\
\text { Alamos }\end{array}$ & 203 & $27^{\circ} 24^{\prime} \mathrm{N}$ & $108^{\circ} 51^{\prime} \mathrm{W}$ & IIAW & $\begin{array}{l}\text { Maximum } \\
\text { Mean } \\
\text { Minimum }\end{array}$ & $\begin{array}{r}28 \\
18 \\
8\end{array}$ & $\begin{array}{r}30 \\
19 \\
8\end{array}$ & $\begin{array}{r}33 \\
21 \\
9\end{array}$ & $\begin{array}{l}37 \\
24 \\
12\end{array}$ & $\begin{array}{l}41 \\
28 \\
16\end{array}$ & $\begin{array}{l}42 \\
31 \\
20\end{array}$ & $\begin{array}{l}39 \\
30 \\
21\end{array}$ & $\begin{array}{l}38 \\
30 \\
21\end{array}$ & $\begin{array}{l}38 \\
29 \\
20\end{array}$ & $\begin{array}{l}37 \\
26 \\
16\end{array}$ & $\begin{array}{l}32 \\
22 \\
12\end{array}$ & $\begin{array}{r}28 \\
18 \\
8\end{array}$ & $\begin{array}{l}35 \\
25 \\
15\end{array}$ \\
\hline San Javier. & 650 & $28^{\circ} 37{ }^{\prime} \mathrm{N}$ & $109^{\circ} 431 \mathrm{~W}$ & IIBCW & $\begin{array}{l}\text { Maximum } \\
\text { Mean } \\
\text { Minimum }\end{array}$ & $\begin{array}{r}16 \\
11 \\
7\end{array}$ & $\begin{array}{r}18 \\
12 \\
7\end{array}$ & $\begin{array}{r}20 \\
14 \\
9\end{array}$ & $\begin{array}{l}23 \\
17 \\
11\end{array}$ & $\begin{array}{l}28 \\
20 \\
13\end{array}$ & $\begin{array}{l}33 \\
26 \\
19\end{array}$ & $\begin{array}{l}31 \\
25 \\
19\end{array}$ & $\begin{array}{l}31 \\
25 \\
18\end{array}$ & $\begin{array}{l}31 \\
24 \\
18\end{array}$ & $\begin{array}{l}26 \\
21 \\
15\end{array}$ & $\begin{array}{l}21 \\
16 \\
10\end{array}$ & $\begin{array}{r}17 \\
12 \\
8\end{array}$ & $\begin{array}{l}25 \\
19 \\
13\end{array}$ \\
\hline $\begin{array}{l}\text { San Luls } \\
\text { R10 Colorado }\end{array}$ & 27 & $32^{\circ} 29^{\prime} N$ & $114^{\circ} 48^{\prime} \mathrm{W}$ & $\begin{array}{c}\text { IIACW } \\
!\end{array}$ & $\begin{array}{l}\text { Maximum } \\
\text { Mean } \\
\text { Min1mum }\end{array}$ & $\begin{array}{r}20 \\
13 \\
5\end{array}$ & $\begin{array}{r}23 \\
15 \\
7\end{array}$ & $\begin{array}{r}26 \\
18 \\
9\end{array}$ & $\begin{array}{l}30 \\
21 \\
13\end{array}$ & $\begin{array}{l}35 \\
26 \\
16\end{array}$ & $\begin{array}{l}39 \\
30 \\
20\end{array}$ & $\begin{array}{l}41 \\
33 \\
25\end{array}$ & $\begin{array}{l}41 \\
33 \\
26\end{array}$ & $\begin{array}{l}39 \\
31 \\
22\end{array}$ & $\begin{array}{l}33 \\
25 \\
17\end{array}$ & $\begin{array}{l}26 \\
19 \\
11\end{array}$ & $\begin{array}{r}21 \\
13 \\
6\end{array}$ & $\begin{array}{l}31 \\
23 \\
15\end{array}$ \\
\hline Santa Ana & 686 & $30^{\circ} 33^{\circ} \mathrm{N}$ & $111^{\circ} 08^{\prime} \mathrm{W}$ & IIIcw & $\begin{array}{l}\text { Maximum } \\
\text { Mean } \\
\text { Minimum }\end{array}$ & $\begin{array}{r}19 \\
11 \\
2\end{array}$ & $\begin{array}{r}20 \\
12 \\
3\end{array}$ & $\begin{array}{r}23 \\
14 \\
5\end{array}$ & $\begin{array}{r}27 \\
17 \\
7\end{array}$ & $\begin{array}{l}32 \\
21 \\
11\end{array}$ & $\begin{array}{l}37 \\
26 \\
16\end{array}$ & $\begin{array}{l}35 \\
28 \\
22\end{array}$ & $\begin{array}{l}34 \\
28 \\
21\end{array}$ & $\begin{array}{l}33 \\
26 \\
18\end{array}$ & $\begin{array}{l}30 \\
21 \\
12\end{array}$ & $\begin{array}{r}24 \\
15 \\
6\end{array}$ & $\begin{array}{r}20 \\
11 \\
3\end{array}$ & $\begin{array}{l}28 \\
19 \\
10\end{array}$ \\
\hline $\begin{array}{l}\text { Santa Rosa } \\
\text { Yecora }\end{array}$ & 1020 & $28^{\circ} 28^{\prime} \mathrm{N}$ & $109^{\circ} 07^{\prime} \mathrm{W}$ & IIBCW & $\begin{array}{l}\text { Maximum } \\
\text { Mean } \\
\text { Minimum }\end{array}$ & $\begin{array}{r}23 \\
14 \\
6\end{array}$ & $\begin{array}{r}25 \\
15 \\
6\end{array}$ & $\begin{array}{r}24 \\
15 \\
6\end{array}$ & $\begin{array}{r}29 \\
19 \\
9\end{array}$ & $\begin{array}{l}32 \\
23 \\
14\end{array}$ & $\begin{array}{l}34 \\
26 \\
19\end{array}$ & $\begin{array}{l}31 \\
25 \\
20\end{array}$ & $\begin{array}{l}2 y \\
24 \\
20\end{array}$ & $\begin{array}{l}31 \\
25 \\
19\end{array}$ & $\begin{array}{l}29 \\
22 \\
15\end{array}$ & $\begin{array}{r}27 \\
18 \\
9\end{array}$ & $\begin{array}{r}25 \\
16 \\
6\end{array}$ & $\begin{array}{l}28 \\
20 \\
12\end{array}$ \\
\hline Sonotta & 398 & $31^{\circ} 56^{\prime} \mathrm{N}$ & $112^{\circ} \mathrm{s} 9^{\prime} \mathrm{W}$ & IIIAcw & $\begin{array}{l}\text { Maximum } \\
\text { Mean } \\
\text { Min1mum }\end{array}$ & $\begin{array}{r}19 \\
11 \\
3\end{array}$ & $\begin{array}{r}22 \\
14 \\
5\end{array}$ & $\begin{array}{r}24 \\
16 \\
7\end{array}$ & $\begin{array}{l}28 \\
19 \\
10\end{array}$ & $\begin{array}{l}33 \\
23 \\
14\end{array}$ & $\begin{array}{l}37 \\
28 \\
18\end{array}$ & $\begin{array}{l}39 \\
32 \\
25\end{array}$ & $\begin{array}{l}38 \\
32 \\
25\end{array}$ & $\begin{array}{l}36 \\
28 \\
21\end{array}$ & $\begin{array}{l}31 \\
23 \\
14\end{array}$ & $\begin{array}{r}25 \\
17 \\
8\end{array}$ & $\begin{array}{r}19 \\
12 \\
4\end{array}$ & $\begin{array}{l}29 \\
21 \\
13\end{array}$ \\
\hline
\end{tabular}


Table A.2.-- Cont inued.

\begin{tabular}{|c|c|c|c|c|c|c|c|c|c|c|c|c|c|c|c|c|c|c|}
\hline \multirow[b]{2}{*}{ Station } & \multirow{2}{*}{$\begin{array}{l}\text { Elevat fon } \\
\text { In Meters }\end{array}$} & \multirow[b]{2}{*}{ Lat Itude } & \multirow[b]{2}{*}{ Long1tude } & \multirow[b]{2}{*}{ Class } & & \multicolumn{13}{|c|}{ Average Monthly Temperature ${ }^{\circ} \mathrm{C}$} \\
\hline & & & & & & $\mathbf{J}$ & $F$ & $\mathbf{M}$ & A & $M$ & $\mathbf{J}$ & $\mathrm{J}$ & A & $\mathrm{s}$ & 0 & $\mathbf{N}$ & D & Annual \\
\hline $\begin{array}{l}\text { Suaqui } \\
\text { Grande }\end{array}$ & 271 & $29^{\circ} 12^{\prime} \mathrm{N}$ & $109^{\circ} 41^{\prime} \mathrm{W}$ & IIACW & $\begin{array}{l}\text { Maximum } \\
\text { Mean } \\
\text { Minimum }\end{array}$ & $\begin{array}{r}25 \\
15 \\
5\end{array}$ & $\begin{array}{r}28 \\
17 \\
6\end{array}$ & $\begin{array}{r}30 \\
19 \\
9\end{array}$ & $\begin{array}{l}35 \\
24 \\
13\end{array}$ & $\begin{array}{l}38 \\
28 \\
17\end{array}$ & $\begin{array}{l}42 \\
33 \\
24\end{array}$ & $\begin{array}{l}39 \\
32 \\
25\end{array}$ & $\begin{array}{l}37 \\
31 \\
24\end{array}$ & $\begin{array}{l}36 \\
31 \\
23\end{array}$ & $\begin{array}{l}36 \\
26 \\
17\end{array}$ & $\begin{array}{r}30 \\
19 \\
9\end{array}$ & $\begin{array}{r}26 \\
16 \\
5\end{array}$ & $\begin{array}{l}34 \\
24 \\
15\end{array}$ \\
\hline $\begin{array}{l}\text { Tres Hermanos } \\
\text { Navajoa }\end{array}$ & 85 & $27^{\circ} 12^{\prime} \mathrm{N}$ & $109^{\circ} 12^{\prime} \mathrm{W}$ & IAw & $\begin{array}{l}\text { Maximum } \\
\text { Mean } \\
\text { Min Imum }\end{array}$ & $\begin{array}{l}27 \\
18 \\
10\end{array}$ & $\begin{array}{l}29 \\
20 \\
10\end{array}$ & $\begin{array}{l}31 \\
21 \\
12\end{array}$ & $\begin{array}{l}35 \\
25 \\
14\end{array}$ & $\begin{array}{l}38 \\
27 \\
17\end{array}$ & $\begin{array}{l}42 \\
31 \\
22\end{array}$ & $\begin{array}{l}39 \\
31 \\
25\end{array}$ & $\begin{array}{l}37 \\
31 \\
24\end{array}$ & $\begin{array}{l}38 \\
30 \\
23\end{array}$ & $\begin{array}{l}36 \\
28 \\
20\end{array}$ & $\begin{array}{l}30 \\
23 \\
14\end{array}$ & $\begin{array}{l}26 \\
20 \\
11\end{array}$ & $\begin{array}{l}34 \\
25 \\
17\end{array}$ \\
\hline Ures & 432 & $29^{\circ} 26^{\prime} \mathrm{N}$ & $110^{\circ} 23^{\prime} \mathrm{W}$ & IIAW & $\begin{array}{l}\text { Maximum } \\
\text { Mean } \\
\text { MIn Imum }\end{array}$ & $\begin{array}{r}24 \\
15 \\
5\end{array}$ & $\begin{array}{r}25 \\
16 \\
6\end{array}$ & $\begin{array}{r}27 \\
17 \\
7\end{array}$ & $\begin{array}{l}33 \\
21 \\
10\end{array}$ & $\begin{array}{l}37 \\
25 \\
13\end{array}$ & $\begin{array}{l}40 \\
29 \\
19\end{array}$ & $\begin{array}{l}40 \\
32 \\
24\end{array}$ & $\begin{array}{l}37 \\
30 \\
23\end{array}$ & $\begin{array}{l}37 \\
29 \\
21\end{array}$ & $\begin{array}{l}34 \\
24 \\
15\end{array}$ & $\begin{array}{r}27 \\
18 \\
9\end{array}$ & $\begin{array}{r}25 \\
16 \\
7\end{array}$ & $\begin{array}{l}32 \\
23 \\
13\end{array}$ \\
\hline Vicam & 46.9 & $27^{\circ} 09^{\circ} \mathrm{N}$ & $110^{\circ} 17^{\prime} \mathrm{W}$ & IIIAw & $\begin{array}{l}\text { Maximum } \\
\text { Mean } \\
\text { Min Imum }\end{array}$ & $\begin{array}{r}26 \\
15 \\
4\end{array}$ & $\begin{array}{r}27 \\
16 \\
6\end{array}$ & $\begin{array}{r}29 \\
18 \\
7\end{array}$ & $\begin{array}{l}33 \\
21 \\
10\end{array}$ & $\begin{array}{l}36 \\
25 \\
14\end{array}$ & $\begin{array}{l}38 \\
29 \\
21\end{array}$ & $\begin{array}{l}39 \\
32 \\
25\end{array}$ & $\begin{array}{l}38 \\
31 \\
24\end{array}$ & $\begin{array}{l}38 \\
30 \\
23\end{array}$ & $\begin{array}{l}35 \\
26 \\
16\end{array}$ & $\begin{array}{r}31 \\
20 \\
9\end{array}$ & $\begin{array}{r}26 \\
16 \\
5\end{array}$ & $\begin{array}{l}33 \\
23 \\
14\end{array}$ \\
\hline Yecora & 1500 & $28^{\circ} 22^{\prime} \mathrm{N}$ & $108^{\circ} 57^{\prime} \mathrm{W}$ & Vcw & $\begin{array}{l}\text { Maximum } \\
\text { Mean } \\
\text { Minimum }\end{array}$ & $\begin{array}{r}15 \\
17 \\
-2\end{array}$ & $\begin{array}{r}18 \\
9 \\
-1\end{array}$ & $\begin{array}{r}18 \\
9 \\
1\end{array}$ & $\begin{array}{r}21 \\
11 \\
1\end{array}$ & $\begin{array}{r}24 \\
14 \\
3\end{array}$ & $\begin{array}{r}28 \\
18 \\
8\end{array}$ & $\begin{array}{l}25 \\
19 \\
13\end{array}$ & $\begin{array}{l}25 \\
18 \\
12\end{array}$ & $\begin{array}{l}24 \\
17 \\
10\end{array}$ & $\begin{array}{r}22 \\
13 \\
4\end{array}$ & $\begin{array}{r}19 \\
\cdot 9 \\
-1\end{array}$ & $\begin{array}{r}16 \\
1 \\
-2\end{array}$ & $\begin{array}{r}21 \\
12 \\
4\end{array}$ \\
\hline
\end{tabular}

1/Source: Servicio Meteorologico Nacional (1976); Centro De Investigaciones Cientificas Y Tecnologicas (1980). 


\section{LITERATURE CITED}

Anderson, B. R. 1975. Weather in the West; From the Mid-Continent to the Pacific. American West Publishing Company, Palo Alto California. 223p.

Baier, W. 1977. Crop-weather models and their use in yield assessments. World Met. Organization Tech. Note No. 151, Geneva, Switzerland. ìMO 440.

Brown, L. H. and J. Cocheme. 1973. A study of the Agroclimatology of the highlands of Eastern Africa. FAO/Unesco/WMO Interagency

Project. Tech. Note No. 125, FAO, Rome. WMO No. 339.

Centro De Investigaciones Cientificas Y Technologicas. 1980. Universidad de Sonora, Hermosillo, Sonora, Mexico, 18.

Conway, H. M. and L. I. Liston. 1974. The Weather Handbook. A summary of weather statistics for selected cities throughout the United States and around the world. Atlanta, Ga., U.S.A. 30341.

Critchfield, H. J. 1974. General climatology. Third edition. Prince-Hall, Inc., Englewood Cliffs, New Jersey. 446p.

Downs, R. J. and H. Hellmers. 1976. Controlled climate and plant research. World Met. Organization Tech. Note No. 148. Geneva, Switzerland. WMO 437.

Durrenberger, R. W. and X. Murrieta. 1978. Climatological data for the state of Sonora, Mexico. Climatological Publications, Mexican Climat. Series No. 3 .

Fairbridge, R. W. 1967. Climatic classifications. The Encyclopedia of Atmospheric Sciences and Astrogeology. Encyclopedia of Earth Sciences Series. 2: 172-185.

Flohn, H. 1969. General climatology. Meteorological Inst. of the Univ. of Bonn. World Survey of Climatology. 2: 88-95.

Gentilli, J. 1952. Present climatic fluctuations in western Australia. West Australian Naturalist. 3: 155-165.

Green, C. R. 1962. Probabilities of temperature occurring in Arizona and New Mexico. Arizona climate Suppl. No. 2. The Institute of Atmospheric Physics, Univ. of Ariz., Tucson. 2: 1-11. 
Green, C. R. and P. C. Kangieses. 1967. Probability of low temperatures occurring in Arizona. Ariz. Climate Supp1. No. 2. The Institute of Atmospheric Physics, Univ, of Ariz., Tucson. MGA 19.5-229.

Griffiths, J. F. $1976 \mathrm{a}$. Climate and the environment. The atmospheric impact on man. M.Sc., A.K.C., D.I.C.; F.R. Geog. S., F.R. Met. S. College of Geosciences, Texas $A$ and $M$ Univ. Paul Elek-London. 102105.

Griffiths, J. F. 1976b. Applied climatology; An Introduction, Second Edition. Texas A and M Univ. 118p.

Hajek, E. R. and J. R. Gutierrez. 1979. Growing seasons in Chile: Observation and prediction. Int. J. Biometeor. Vol. 23, No. 4: 311-329.

Howe, G. M., I. J. Read, J. J. Ball, G. E. Fisher and G. B. Lasson. 1968. Classification of world desert areas. U.S. Army, Natick Lab. Tech. Report, 69-38-ES .

Jurwitz, L. R. and P. C. Kangieser. 1978. Climates of the states; Ariz. normals, means and extremes tables revised 1973 and 1975. Basic report revised 1959. Climatology of the United States No. 60-2.

Keulen, H. V. and W. Louwerse. 1974. Simulation models for plant production. Agroclimatology of the wheat crop-proceedings of the WMO Symposium. Braunschweig, Federal Republic of Germany, 1973. Published on behalf of WMO by the Deutscher Wetterdienst, WMO No. 396.

Koppen, W. 1918. Klassification der klimate nach temperature, Niederschlag and Jahresverlauf. Petermann's Geograph. Mitt. 64 : 193-203.

Landsperg, H. E. 1972. The assessment of human bioclimate. A Iimited review of physical parameters. World Meteorological Organization No. 331, Tech. Note No. 123, Geneva, Switzerland, WMO No. 331.

Lomas, J. 1976. Meteorological requirements of the wheat crop. Agroclimatology of the wheat crop-proceedings of the WMO symposium. Braunschweig, Federal Republic of Germany, 1973. WMO No. 396 (Supplement) 1-29.

Maunder, W. J. 1968. A groclimatological relationship. A review. Can. Geogr. 12: 73-84.

McBoyle, G. R. 1972. Factor analytic approach to a climatic classification of Europe. Climatological Bulletin No. 12. McGill University, Montreal, 1-11. - 
McColm, G. L. 1948. Crop growing season map of South Vietnam. Based on world-wide crop growing season classification. McColm, American Society of Agronomy Meeting, 1948.

McColm, G. L. and R. Dennis. 1980. Growing seasons of Arizona. University of Arizona Cooperative Extension Service. Agri-File Field Crops 200.2.

Newman, J. E. and J..Y. Wang. 1959. Defining agricultural seasons in the middle latitude. Agronomy Journal. 51: 579-582.

Papadakis, J. 1975. Climates of the world and thelr potentialities. Av. Cordoba 4564. Buenos Aires, Argentina 200p.

Perrin de Brichambaut, G. and C. C. Wallen. 1963. A study of agroclimatology in semi-arid and arid zones of the near east. World Meteor. Organization No. 141, Tech. Note No. 56. Geneva, Switzerland, WMO No. 141.

Rex, D. F. 1969. Climate of the free atmosphere. National Centre for Atmos. Res., Boulder, Colorado, U.S.A. World Survey of Climatology, 4: 47-56.

Rilley, D. and I. Spolton. 1974. World weather and climate. Cambridge University Press 120p.

Riordan, P. 1970. Weather extremes around the world. Tech. Rep. 7045-ES. U.S. Army, Natick Lab., Massachusetts. 01760.

Ruffner, J. A. and F. E. Bair. 1977. The weather almanac. Gale Research Company, Book Tower, Detroit, Michigan. 2: 347-358.

Ruffner, J. A. 1978. Climates of the States. National oceanic and atmospheric administration narrative summaries, tables, and maps for each state with current tables of normals 1941-1970, means and extremes to 1975. Overview of state climatologist programs. Vol. $I: 48-68$.

Sellers, W. D. and R. H. Hill. 1974. Arizona climate 1913-1972. The University of Arizona Press, Tucson, Ariz. 503p.

Servicio Meteorologico Nacional. 1976. Direccion General De Geografica Y. Meteorologica. Normales Climatologicas Perlodo 19411970. Mexico, Sonora 646-673.

Sharon, D. 1968. The distribution of the longest temperature duration in a month. Tech. Rep. 69-35-ES. U.S. Army, Natick Lab., Massachusetts 01760. 
Shaw, R. H. 1965. Ground level climatology. A symp. presented at the Berkeley Meeting of the American Assoc. for the Advancement of Science. Washington D.C., Publication No. 86.

Skaar, E. 1980. Application of meteorological data to agroclimatological mapping. Int. J. Biometeor., Vol. 24, No. I: 3-12.

Smith, H. V. 1956. The climate of Arizona. Agric. Exp. Station Bull. No. 279, University of Arizona, Tucson, Ariz. 98p.

Smith, J. W. 1963. The vertical temperature distribution and the layer of minimum temperature. J. Appl. Meteorol., 2(5): 655-667.

Smith, K. 1975a. Principles of applied climatology. The University of Strathclyde, Scotland. John Wiley and Sons, New York, 291p.

Smith, L. P. 1975b. Methods in agricultural meteorology. Developments in atmospheric science, 3. El Sevier Scientific Publishing Co., Amsterdam. 210p.

Stallings, J. I. 1961. A measure of the influence of weather on crop production. Journ. Farm Econ., 43: 1153-62.

Taylor, J. A. 1967. Growing season as affected by land aspect and soil texture. In Taylor J. A. (ed.) weather and agric. Pergamon Press. 15-36.

Thompson, L. M. 1975. Weather variability; climatic change and grain production. Science, 188: 535-541.

Thornthwaite, C. W. 1931. The climate of North America. Geographical Review. 21: 633-655.

Thornthwaite, C. W. 1933. The climate of the earth. Geographical Review.' 23 : $433-440$.

Thornthwaite, C. W. 1948. An approach toward a rational classification of climate. Geographical Review. 38: 55-95.

Trewartha, G. T. 1954. An introduction to climate. Third edition. University of Wisconsin, McGraw-Hill Publishing Co., N.Y. 399p.

Trewartha, G. T. 1968. An introduction to climate. Fourth edition. University of Wisconsin, McGraw-Hill Publishing Co., N.Y. 399p.

UNESCO. 1958. Climatology and microclimatology. Proceedings of the Canberra Symposium. Arid Zone Research XI. UNESCO, Paris. 355p. 
U.S. Committee for the Global Atmospheric Research Program. 1975. National research council. Understanding climatic change: A program for action. National Academy of Sciences, Washington, D.C. 239p.

U.S. Department of Agriculture. 1962. Plant hardiness zone map. U.S. National Arboretum. Agric. Res. Service, miscellaneous publication No. 814.

U.S. Department of Agriculture. 1980. Weather Bureau. Monthly weather review series, 1889-1979.

U.S. Department of Agriculture and U.S. Department of Commerce. 1981. Weekly weather and crop bulletin. NOAA/USDA Joint Agricultural Weather Facility: 5 .

U.S. Environmental Data Service. 1980. Local climatological data, Arizona. Monthly Series with annual summaries, 80.

Utaaker, K. 1980. Local climates and growth climates of the SognefJord region. Int. J. Biometeor., Vol. 24, No. I: 13-22.

Walter, H., E. Harnickell and D. Muller-Dombios. 1975. Climatediagram maps. Ind. Countries and the ecological climatic regions of the earth. Suppl. to the veg. monographs, 8-11.

Wernstedt, F. L. 1972. World climatic data. Pennsylvania State University. Climatic Data Press. 522p.

Westbrook, J. H. 1969. Relationships of hourly durations of the daily maximum temperature. Tech. Report 69-87-ES. U.S. Army, Natick Lab., Massachusetts 01760 .

World Meteorological Organization. 1965. Short-period averages for 1951-1960 and provisional average values for climatetemp and climate temp ship stations. Geneva, Switzerland. WMO No. 170, TP84.

World. Meteorological Organization. 1980. Monthly climatic data for the world. U.S. Env. Data Service. WMO Current Issues, 80. 


$$
6682-2
$$

